\title{
Influence of chemical compounds and cell- autonomous immunity on the replication of sexually transmitted pathogens
}

Ph.D. Thesis

Rafai Tímea

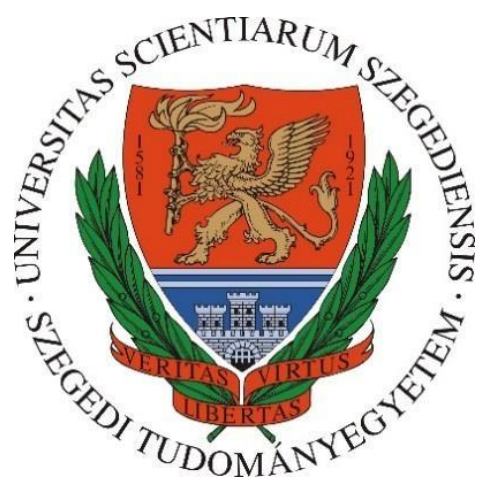

Supervisor:

Dezső Virok M.D., Ph.D

Department of Medical Microbiology and Immunobiology

Faculty of Medicine

University of Szeged

Szeged

2019 


\section{PUBLICATIONS RELATED TO THIS THESIS}

I. Raffai, T., Burián, K., Janovák, L., Bogdanov, A., Hegemann, J.H., Endrész, V., Virok, D.P.: Vaginal Gel Component Hydroxyethyl Cellulose Significantly Enhances the Infectivity of Chlamydia trachomatis Serovars D and E. Antimicrob Agents Chemother. 63, e02034-18, /aac/63/1/AAC.02034-18.atom (2018). doi:10.1128/AAC.02034-18

IF:4.715

II. Rédei, D., Kúsz, N., Rafai, T., Bogdanov, A., Burián, K., Csorba, A., Mándi, A., Kurtán, T., Vasas, A., Hohmann, J.: 14-Noreudesmanes and a phenylpropane heterodimer from sea buckthorn berry inhibit Herpes simplex type 2 virus replication. Tetrahedron. 75, 1364-1370 (2019). doi:10.1016/j.tet.2019.01.050

IF:2.379

III. Virok, D.P., Raffai, T., Kókai, D., Paróczai, D., Bogdanov, A., Veres, G., Vécsei, L., Poliska, S., Tiszlavicz, L., Somogyvári, F., Endrész, V., Burián, K.: Indoleamine 2,3-Dioxygenase Activity in Chlamydia muridarum and Chlamydia pneumoniae Infected Mouse Lung Tissues. Front. Cell. Infect. Microbiol. 9, 192 (2019). doi:10.3389/fcimb.2019.00192

IF:3.520

$\sum$ IF:10.614

\section{PUBLICATIONS NOT RELATED TO THIS THESIS}

I. Klement, E., Raffai, T., Medzihradszky, K.F.: Immobilized metal affinity chromatography optimized for the analysis of extracellular phosphorylation. Proteomics. 16, 1858-1862 (2016). doi: $10.1002 /$ pmic. 201500520

IF:2.470

II. Csábi, J., Rafai, T., Hunyadi, A., Zádor, E.: Poststerone increases muscle fibre size partly similar to its metabolically parent compound, 20-hydroxyecdysone. Fitoterapia. 134, 459-464 (2019). doi:10.1016/j.fitote.2019.03.017

IF:2.431

III. Vanić, Ž., Rukavina, Z., Manner, S., Fallarero, A., Uzelac, L., Kralj, M., Amidžić Klarić, D., Bogdanov, A., Raffai, T., Virok, D.P., Filipović-Grčić, J., Škalko-Basnet, N.: Azithromycinliposomes as a novel approach for localized therapy of cervicovaginal bacterial infections. IJN. Volume 14, 5957-5976 (2019). doi:10.2147/IJN.S211691 
TABLE OF CONTENT

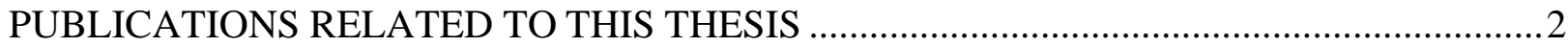

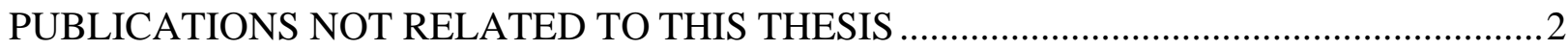

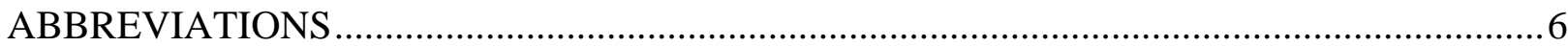

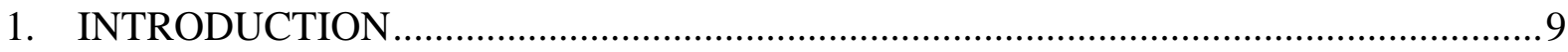

1.1. Taxonomy and microbiology of the Chlamydia genus ...........................................

1.2. Pathogenesis of Chlamydia trachomatis infection and the host response .................10

1.3. Impact of vaginal gels on Chlamydia trachomatis infection ................................... 13

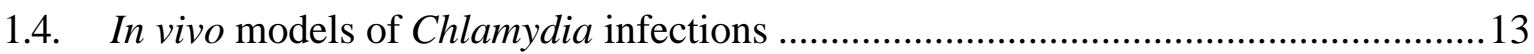

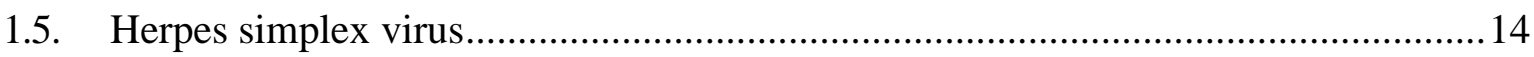

1.6. Microbiology and pathology of herpes simplex virus-2 ..................................... 14

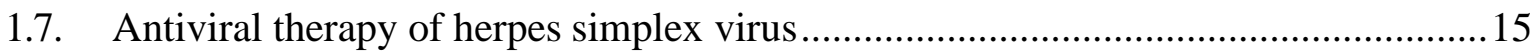

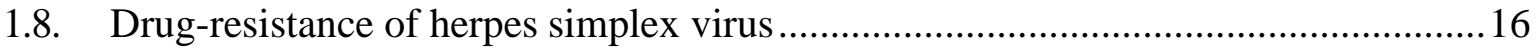

1.9. Novel antiviral treatments of herpes simplex virus .............................................. 17

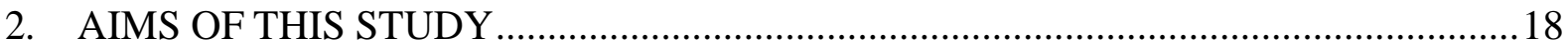

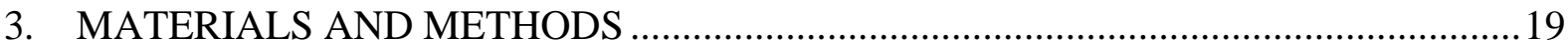

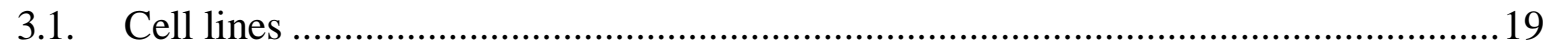

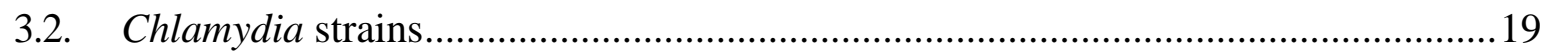

3.3. Extracted compounds from Elaeagnus rhamnoides and Rumex aquaticus ............... 19

3.4. Preparation of hydroxyethyl cellulose solution in vaginal simulant buffer ..............20

3.5. Investigation of impact of hydroxyethyl cellulose on Chlamydia trachomatis

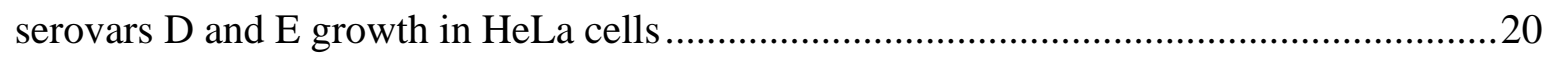

3.6. Monitoring the growth of Chlamydia trachomatis serovars D and E by direct quantitative PCR

3.7. Monitoring the growth of Chlamydia trachomatis strains D and E by chamber slide method

3.8. Investigating the in vivo effect of hydroxyethyl cellulose on growth of Chlamydia trachomatis serovar D 
3.9. Infection of BALB/c and C57BL/6 mice with Chlamydia pneumoniae and

Chlamydia muridarum and processing of the lung tissues.

3.10. Culturing of Chlamydia pneumoniae and Chlamydia muridarum from BALB/c mouse lungs .23

3.11. Inhibition of indoleamine 2,3-dioxygenase by 1-methyl-DL-tryptophan in BALB/c mice 24

3.12. Total RNA extraction and cDNA synthesis from Chlamydia infected and uninfected $\mathrm{BALB} / \mathrm{c}$ and $\mathrm{C} 57 \mathrm{BL} / 6$ mouse lungs

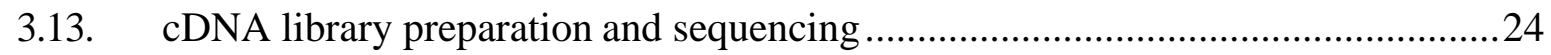

3.14. Statistical and functional analysis of RNA-sequencing data..............................25

3.15. Quantitative PCR validation of the IDO1 and IDO2 RNA-Seq data ....................25

3.16. IDO1 and IDO2 immunohistochemistry of Chlamydia pneumoniae and Chlamydia muridarum infected and uninfected BALB/c mouse lungs

3.17. Measurement of tryptophan and kynurenine concentrations in Chlamydia pneumoniae and Chlamydia muridarum infected and uninfected BALB/c and C57BL/6 mouse lung tissues.

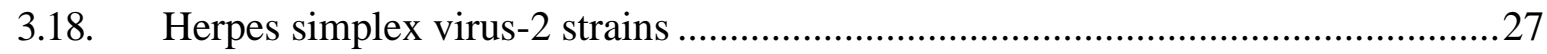

3.19. 3-(4,5-Dimethylthiazol-2-yl)-2,5-diphenyltetrazolium bromide (MTT) assay ......27

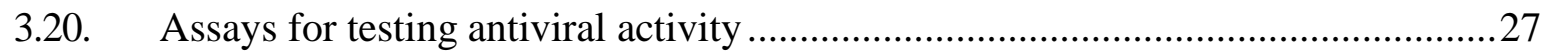

3.21. Measuring antiviral activity by direct quantitative PCR …..............................28

3.22. Determination of TCID 50 by the virus yield reduction technique .........................28

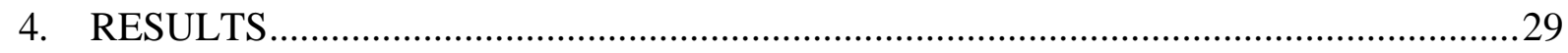

4.1. Monitoring the impact of hydroxyethyl cellulose on the growth of Chlamydia trachomatis serovar $\mathrm{D}$ and $\mathrm{E}$ by quantitative PCR .........................................................29

4.2. Monitoring the impact of hydroxyethyl cellulose on the growth of Chlamydia trachomatis strains D and E by chamber slide method

4.3. Investigating the in vivo effect of hydroxyethyl cellulose on growth of Chlamydia trachomatis serovar D

4.4. Chlamydia infection and Chlamydia-induced histopathology in BALB/c mouse lung tissues 
4.5. Impact of Chlamydia muridarum infection on the global gene expression of BALB/c mouse lung tissues.

4.6. Antimicrobial genes induced by Chlamydia muridarum infection in BALB/c mouse lung tissue.

4.7. qPCR validation of $I D O 1$ and IDO2 RNA-sequencing data 35

4.8. IDO1-2 protein expression in Chlamydia muridarum and Chlamydia pneumoniae infected BALB/c mouse lung tissues 36

4.9. IDO 1-2 activity in Chlamydia muridarum and Chlamydia pneumoniae infected $\mathrm{BALB} / \mathrm{c}$ mouse lung tissues

4.10. IDO 1-2 mRNA expression and activity in Chlamydia muridarum infected C57BL/6 mouse lung tissues

4.11. Antiviral activity of compounds $1-3$ and 5-8 39

5. DISCUSSION

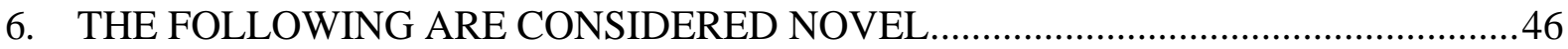

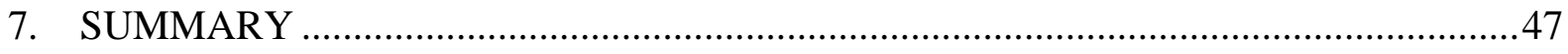

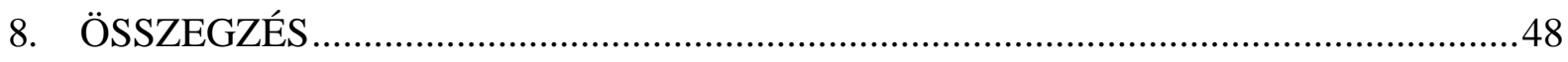

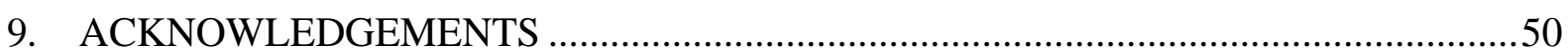

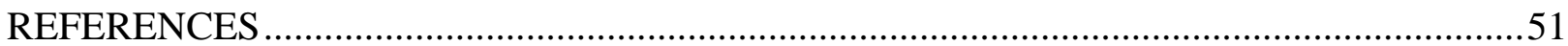




\section{ABBREVIATIONS}

1-MT- 1-methyl-DL-tryptophan

3NLT- 3-nitro L-tyrosine

ACV-acyclovir

CCL- chemokine C-C motif ligand

CD - cluster of differentiation

C. muridarum- Chlamydia muridarum

C. pneumoniae- Chlamydia pneumoniae

C. trachomatis- Chlamydia trachomatis

Compound 1- 6,9-dihydroxy-1-ox-14-noreudesm-5,7,9 triene

Compound 2- 2-hydroxy-7-isopropyl-1-methoxy-4-methyl-1,4-naphthoquinone

Compound 3- methoxy-substituted phenylpropane dimer

Compound 4- caulexin $\mathrm{C}$

Compound 5- musizin

Compound 6- musizin-8-O-glucoside

Compound 7- torachrysone-8-O-glucoside

Compound 8- 2-methoxystipandron

CPE- cytopathic effect

Ct- cycle threshold

CXC- C-X-C motif

DC- dendritic cell

DMSO- dimethyl sulfoxide

DNA- deoxyribonucleic acid

EB- elementary body

E. rhamnoides- Elaeagnus rhamnoides

FBS- fetal bovine serum

HEC- hydroxyethyl cellulose

HPLC- high-performance liquid chromatography

HSPs- heat shock proteins

HSV - herpes simplex virus

iBALT- inducible bronchus associated lymphatic tissue

IDO-indoleamine 2,3-dioxygenase 
ICAM- intercellular adhesion molecule

IDU- iododeoxyuridine

IFN- $\boldsymbol{\gamma}$ - interferon-gamma

IFU- inclusion forming unit

IHC-immunohistochemistry

IIGP- interferon inducible GTPase

IL- interleukin

iNOS- inducible nitric oxide synthase

IRF- interferon regulatory factor

IRG- immune-responsive gene

KEGG- Kyoto Encyclopedia of Genes and Genomes

KLRA- natural killer cell lectin-like receptors

KYNU-kynurenine

LGV- lymphogranuloma venereum

LPS- lipopolysaccharide

MCP- monocyte chemoattractant protein

MEM- minimal essential medium

MHC- major histocompatibility complex

MIG- monokine induced by gamma-interferon

MOMP- major outer membrane protein

MOI- multiplicity of infection

MQ- Milli-Q water

mRNA- messenger ribonucleic acid

MTT- 3-(4,5-Dimethylthiazol-2-yl)-2,5-diphenyltetrazolium bromide

NK- natural killer

NO- nitrogen-monoxide

NOD- nucleotide-binding oligomerization domain

PAMPs- pathogen-associated molecular patterns

PBS- phosphate buffer saline

PCV- penciclovir

qPCR- quantitative polymerase chain reaction

QTL- quantitative trait locus

\section{R. aquaticus- Rumex aquaticus}

RB- reticulate body

RIG- retinoic acid-inducible gene 
RNA-Seq- RNA-sequencing

TCID $_{50}$ - Tissue Culture Infectious Dose

s.c.- subcutaneous

SPG- sucrose-phosphate-glutamic acid buffer

STAT- signal transducer and activator of transcription

STDs- sexually transmitted diseases

TK- thymidine kinase

TLR- toll-like receptor

TNF $\alpha$ - tumor necrosis factor-alpha

VCAM-1 vascular cell adhesion molecule 1 


\section{INTRODUCTION}

Sexually transmitted diseases (STDs) are a persistent and significant problem globally. Worldwide more than 1 million STDs are acquired every day and the incidence is increasing [1]. Chlamydia trachomatis (C. trachomatis) infections are one of the most prevalent STDs [2]. In 2016 1.589.354 C. trachomatis infections were reported in the United States and the number of reported infections steadily increased from 2000 to 2016, reaching 497.3 cases per 100.000 population [3]. The less common $C$. trachomatis L1-3 serovars cause lymphogranuloma venereum (LGV). $1416 \mathrm{LGV}$ cases were reported in 21 countries and the number of cases increased from 2013 to 2014 by 32\% [4]. The age difference between menarche and marriage is continuously rising leading to an increase of the sexually active and potentially more promiscuous population [5] [6]. Many STDs have no symptoms or have only mild symptoms that may not be sufficient to recognize and treat the disease. The lack of eradication leads to the uncontrolled spread of STDs. Persistent and latent-reactivating infections also make eradication hard or impossible. Chlamydia and different herpesvirus species prefer an intracellular lifestyle where the infection persists for months-years to lifetime. Latent-reactivating herpes virus simplex (HSV) infections, the causative agent of herpes genitalis affects more than 500 million people worldwide $[1]$.

My thesis focuses on the Chlamydia and HSV-2 growth-altering effects of various compounds, and also aims to identify murine defense genes involved in the elimination of Chlamydia strains.

\subsection{Taxonomy and microbiology of the Chlamydia genus}

The order Chlamydiales contains several species, including the human pathogens $C$. trachomatis and C. pneumoniae [7]. Based on biological characteristics C. trachomatis species can be grouped into 2 biovars which can be further divided into various serovars [8]. The trachoma biovar includes the ocular serovars: A, B, Ba, C and the genital serovars D, E, F, G, H, I, J, K. LGV biovar consists of serovars L1, L2, L2a, L2b and L3 [9] [10]. Infections related to the urogenital serovars D-K include urethritis, cervicitis and pelvic inflammatory disease in adults. Perinatal transmission of the genital serovars leads to conjunctivitis, pharyngitis and pneumonia in the newborns [11]. Prevalence of LGV biovars is lower, but can be high in certain geographical areas such as regions in Africa, Southeast Asia, India, the Caribbean, and South America [12]. In the last 10 years, LGV prevalence increased in North America and Europe causing outbreaks among 
men who have sex with men [13]. C. pneumoniae is a respiratory pathogen associated with acute and chronic inflammatory diseases such as respiratory tract infections, asthma and atherosclerosis [14]. C. muridarum is the closely related murine strain of $C$. trachomatis and a causative agent of mouse pneumonitis [15].

Chlamydiae are obligate intracellular bacteria that propagate prominently in the epithelial cells of the respiratory and urogenital tract [16] [17]. They exist in two morphological forms, the infectious elementary body (EB) and the non-infectious, but metabolically active reticulate body (RB) [18]. The EB attaches to cell surface components of mucosal epithelial cells such as heparin sulfate proteoglycan and enters the host cell by various ways. Following the entry, the EBs are transported to the perinuclear area of the cell [17], where they are located in a large membrane bound compartment, the so-called inclusion [19]. During this process, certain chlamydial proteins, such as inclusion membrane proteins interact with different membrane sorting proteins of the host cell inhibiting the fusion with lysosomes [20]. Inclusion membrane proteins also interact with nutrient-rich host compartments such as Golgi derived vesicles. During primary differentiation the EBs transform into RBs [21], and the RBs replicate by binary fission. Depending on the Chlamydia strain, after 24-72 hours the second differentiation takes place, where the replicated RBs re-differentiate to EBs. At the end of the developmental cycle, infectious EBs are released by exocytosis or extrusion, ready to infect other cells [22].

\subsection{Pathogenesis of Chlamydia trachomatis infection and the host response}

Epithelial cells, the main targets of the Chlamydia infections are not professional immune cells, although they possess a so-called autonomous cell immunity. Toll-like receptors (TLR) expressed on the innate immune cells and the epithelial cells are able to recognize pathogen-associated molecular patterns (PAMPs) of the Chlamydia [23]. Chlamydiae have several components that may serve as PAMPs. TLR2 and TLR4 has been described as a receptor for chlamydial ligands, such as lipopolysaccharide (LPS) and heat shock proteins (HSPs) [24]. The ligation of the TLRs by PAMPs of infected epithelial cells, induces the production of pro-inflammatory cytokines [25]. Pro-inflammatory cytokines attract leukocytes including neutrophil granulocytes, monocytes and dendritic cells (DCs). These locally activated leukocytes, especially neutrophils and macrophages produce a second wave of cytokines [24]. attracting other cells such as T lymphocytes, B lymphocytes and natural killer (NK) cells [26]. Infected epithelial cells, DCs, macrophages and neutrophils present chlamydial antigens on their major histocompatibility complex (MHC) receptors. These antigen presenting cells are able to activate T lymphocytes, initiating a cell- 
mediated and humoral adaptive immune response. Antigen presenting cells, including epithelial cells presenting the antigen by MHC-I receptors activate CD8+ T cytotoxic cells, while professional antigen presenting immune cells activate the CD4+ T helper cells by their MHC-II receptors. CD8+ $\mathrm{T}$ cells induce death of infected cells. CD4+ cells based on their profile of cytokine production are divided further to Th1 and Th2 cells [27]. Th1 response is directed against intracellular pathogens [28], Th1 cells produce interferon-gamma (IFN- $\gamma$ ), inducing cellular immunity and activating innate immune cells which participates in chlamydial infection related inflammation [29]. Another part of the adaptive immunity is the B lymphocyte response. B lymphocytes differentiate to plasma cells producing antibody and accomplish immunological memory against the pathogen [30]. In the genital mucosa, specific local antibodies are secreted for the resolution of primary and secondary infections [31]. These antibodies include monoclonal immunoglobulin A (IgA) and immunoglobulin G (IgG) [32] [33]. Antibodies recognizes specific epitopes in MOMPs and HSP proteins of Chlamydia [34] [35]. MOMP specific monoclonal antibodies neutralize the extracellular form of Chlamydia and enhances the cellular immune responses during reinfection [36] [37]. The HSP specific antibodies in serum shows elevated level in case of serious infections [38] [39]. Innate immunity is the first line of defense against Chlamydia infections, while the adaptive immune response is involved in final elimination of the bacterium and provides protection against recurrent infections by creating immunological memory. At the tissue level, the adaptive and innate immunity are strongly linked, the communication and coordination of its elements are accomplished by cytokines. The proinflammatory cytokines produced first by the infected epithelial cells, include interleukin-1-alpha and interleukin-1-beta (IL-1 $\alpha$, IL-1 $\beta$ ), tumor necrosis factor-alpha (TNF $\alpha$ ), IL-8 and IL-6 [40]. IL-8 attracts of leukocytes to the site of the infection and enhances the expression of adhesion molecules ICAM-1 and VCAM-1 [41] [42] [43] [44]. Several other cytokines such as IL-10, IL12, IL-15 are implicated in the infections with different activating or regulatory roles [45] [46] [47]. IFN- $\gamma$, a key cytokine in chlamydial infections is produced by NK and Th1 cells [48]. Among the diverse effects of IFN- $\gamma$, it induces the expression of the host enzyme indoleamine 2,3dioxygenase (IDO) in infected cells influencing tryptophan availability in these cells [49] [50] [51]. Tryptophan degradation occurs via the kynurenine pathway, where the IDO catalysis first step of the catabolism, the oxidation of L-tryptophan to N-formylkynurenine [52]. Since Chlamydia is a tryptophan auxotroph, the limitation of tryptophan availability is an effective defense strategy of the host cell [53]. IFN- $\gamma$ also upregulates other host defense genes, such as the inducible nitric oxide synthase (iNOS) enzyme, which catalyzes the production of reactive nitrogen intermediates, most notably nitric oxide (NO) [54]. IFN- $\gamma$ also downregulates host transferrin receptors on the infected cells, resulting in intracellular iron deficiency and limitation 
of the pathogen's replication [55]. Besides orchestrating anti-chlamydial defense responses, IFN$\gamma$ and the other locally produced cytokines have a complex effect on tissue-level gene/protein expression and metabolism, including the production of reactive oxygen species, matrix metalloproteases, elastases, collagenases, cathepsins. The production of these proteins during acute and chronic inflammation eventually leads to tissue remodeling, fibroblast proliferation and extracellular matrix production [56][57].

Despite the significant Chlamydia-induced inflammation, the majority of the infections caused by C. trachomatis are asymptomatic and therefore remain untreated [57]. In the male population the infections remain asymptomatic in $75 \%$ of cases, while in female populations it may reach up to $76.7 \%$ [58]. The symptomatic cases of men could manifest non-gonococcal urethritis involving mucopurulent discharge, painful urination, epididymitis, epididymo-orchitis, prostatitis and proctitis. The symptoms in females include mucopurulent cervicitis, urethritis in the lower urogenital tract, and by ascending to the upper genital tract, the infection may induce chronic inflammation resulting in pelvic inflammatory disease, endometritis, and salpingitis [59] [24] [60]. The major clinical problem is that untreated $C$. trachomatis infections can eventually lead to oviduct obstruction with infertility or ectopic pregnancy [61].

C. trachomatis LGV strains causes invasive, ulcerative urogenital and anorectal infections [20]. The pathogen enters through skin breaks or abrasions, infect the epithelial layers of the mucosal membranes and local macrophages and travels to the regional lymph nodes leading a necrosis heading and abscess formation [62]. The clinical manifestation of the disease involves three major stages [63]. Following the incubation period, the primary stage lasts 3-30 days and may remain undetected. Painless papule, pustule and ulceration appears at the entry site of the infections. The second stage begins within 2-6 weeks after the onset of the primary stage. During the second stage, systemic symptoms (fever/arthritis/pneumonitis/perihepatitis) occur alongside lymphadenitis (intra-abdominal or retroperitoneal lymphadenopathy, inguinal and/or femoral lymphadenopathy) followed by bubo formation (fluctuant and suppurative lymph nodes that may rupture) [64]. Without proper treatment the infection can be chronic and the lymphadenopathy can persist for years. In the third stage the chronic infection leads to chronic proctitis, fistulae, strictures, stenosis of the rectum genital lymphedema, elephantiasis in men, and proctitis, rectovaginal fistulas and urethral destruction and elephantiasis of the vulva (esthiomene) in women [65]. 


\subsection{Impact of vaginal gels on Chlamydia trachomatis infection}

When the initial infection is symptomatic, treatment with antimicrobial agents is usually efficient by resolving the infection and consequently the inflammation as well [66]. C. trachomatis is susceptible to antibiotics such as macrolides, tetracyclines, quinolones and sulfonamides [67]. However, most infections caused by $C$. trachomatis remain undetected and untreated, persist from weeks to months leading to the serious sequalae described previously [68]. The high prevalence of repeated infections with the same or different serovars of $C$. trachomatis may also contribute to the severe outcome [59].

Since the effective treatment is not available in the majority of the infections, prevention of transmission would be an important strategy to limit the complications of Chlamydia infections. The Chlamydia transmission is greatly influenced by components of the cervico-vaginal microenvironment including vaginal lactobacilli and indole-positive bacteria [69]. Vaginal gels also can be introduced into this microenvironment as lubricants or therapeutic gels. Vaginal gels are present during sexual intercourse and therefore may have a significant impact on the acquisition of Chlamydia infection and other STDs. A major component of vaginal gels is the gelling agent itself, therefore we can assume that they have an effective concentration to inhibit or support chlamydial propagation. A variety of gelling agent are used in the commercially available products including the commonly used hydroxyethyl cellulose (HEC) that can be found both in lubricants and in therapeutic gels [70]. Despite their potential importance in transmission, the impact of gelling agents including HEC on the propagation of $C$. trachomatis is not welldescribed.

\subsection{In vivo models of Chlamydia infections}

The prevention of Chlamydia infections by vaccination would be an effective solution to limit infection transmission, but effective vaccines have not yet been developed. Mouse models are the most frequently used ones for vaccine development, but the differences between the human and murine immune systems, including the so-called cell-autonomous immunity makes the mouse models difficult to compare with humans [71]. Cell-autonomous immunity is an intrinsic feature of the host cells, which launches defense mechanisms that interfere with the growth of intracellular pathogens. Typically, these defense genes are inducible and IFN- $\gamma$ is a prominent inducer cytokine. It has been described earlier that the major intracellular anti-chlamydial defense 
mechanism in human cells is the IFN- $\gamma$ induced IDO expression, which leads to the degradation of the intracellular tryptophan pool and eventually the death of the tryptophan-auxotroph $C$. trachomatis [72]. This elimination mechanism is effective in vitro for both the human $C$. trachomatis and the genetically closely related murine Chlamydia species C. muridarum [73]. Nevertheless, in vitro data showed that IDO is not induced by Chlamydia infection and/or IFN- $\gamma$ in mouse epithelial cells [73]. Instead, microarray analysis of IFN- $\gamma$ treated and Chlamydia infected murine epithelial cells revealed that the IFN-inducible GTPases are the suspected host genes that interfere with the developmental cycle of human Chlamydia strains [74]. The murine Chlamydia strain developed mechanism(s) to deactivate the GTPase response and render this elimination mechanism ineffective [74][75]. Despite this, the C. muridarum strain is rapidly eliminated from the murine cervicovaginal tract [74], hence yet unknown elimination mechanisms exist in mice that are effective against the murine Chlamydia strain in vivo.

\subsection{Herpes simplex virus}

The herpes simplex virus belongs to the family of Herpesviridae, comprising two species: HSV1, which principally causes herpes labialis and HSV-2, the major causative agent of herpes genitalis. Surveys show that more than 3.7 billion people under the age of 50 are infected with HSV-1 and 417 million people between 17 and 49 years of age are infected with HSV-2 [76]. Both HSV-1 and HSV-2 cause herpes genitalis and while the majority of cases is caused by HSV2, the prevalence of HSV-1 related herpes genitalis is increasing due to the practice of oral sex [77] [78]. HSV-1 and HSV-2 share many common biological features including infection of mucosal epithelial cells and latent infection in ganglions. HSV-1 accomplishes lifetime latencyin the trigeminal ganglion while HSV-2 remains in sacral ganglia [79] [80].

\subsection{Microbiology and pathology of herpes simplex virus-2}

The HSV virions are relatively large enveloped viruses consisting of double stranded linear DNA surrounded by an icosahedral capsid and a protein layer, the tegument. The glycoproteins of the envelope are good antigens and are the bases of serological differentiation between HSV types [81]. The primary transmission of HSV-2 occurs through direct contact and is usually asymptomatic [82]. The virion attacks the epithelial cells and neurons and in serious cases the 
infection can also affects the perivascular tissues [83]. Macular or papular skin and mucous membrane lesions occur 4-7 days after sexual contact; these progress to vesicles, pustules and ulcers which can last from 3 to 6 weeks [84]. When healing occurs, no residual scarring or ulceration is left. The lesions are frequently extensive, involving the labia majora, labia minora, perianal skin, vestibule of the vulva, as well as the vaginal and ectocervical mucosa [85]. Typical symptoms also include pain, especially painful inflammatory swelling of the vulva in women, burning pain and dysuria. Lymphadenopathy, fever and cervicitis (in women) or proctitis (in men) are relatively common associated symptoms. The HSV virion is transported through retrograde axonal transport to the sacral ganglia and establishes latency there [86] [87]. The immune system may control the latent infection and recurrence is not observable in these patients. Temporary or sustained suppression of the immune system could be caused by numerous physiological and environmental factors such as fever, emotional influences, hormonal changes, trauma, stress, exhaustion, immunosuppression or other infection. HSV reactivation can be frequent and in the majority of the cases is characterized by asymptomatic genital viral shedding [88].

Both people with symptomatic herpes genitalis and asymptomatic shedding can transmit the virus to their sexual partners. This almost always occurs via direct contact during sexual intercourse. Intrauterine and perinatal viral transmission are also a clinical possibility [89]. Both primary and recurrent HSV infections in pregnant women can result in intrauterine viral transmission causing congenital HSV infections in newborns. The clinical consequences of fetal infection include abortion, stillbirth or other congenital manifestations usually involving skin and eye lesions and neurological symptoms [90] [91] [92] [93]. HSV transmission during labor is regarded as the most common source of neonatal HSV infection [94].

\subsection{Antiviral therapy of herpes simplex virus}

Inhibiting viral DNA synthesis is an effective strategy to counter viral replication. The first antivirals developed against HSV were the halogenated nucleoside analogs idoxuridine and trifluridine [95]. They incorporate into the nascent viral DNA strand but due to the halogens in their bases inhibit base pairing. The DNA synthesis of the host cell is also influenced due to the non-selectivity of these drugs, leading to high toxicity when they are systemically administered [78].

HSV encodes a viral thymidine kinase, which could be utilized to increase selective toxicity in only in the infected cells. Acyclovir (ACV), valacyclovir, penciclovir (PCV) and famciclovir have 
selective mechanisms of action since they are about a hundred times more likely phosphorylated by the virus TKs than the host cells TKs [96] [97]. After the first phosphorylation, the subsequent phosphorylations are performed by host kinases resulting the triphosphate form that can incorporate to the newly synthesized DNA strand. Once these nucleoside analogs are incorporated, they terminate the DNA synthesis due to their modified sugar constituents [82].

Currently these nucleoside analogs are standard first-line drugs against HSV infections. ACV is the first of choice therapeutic agent, administered topically in case of herpes labialis and mildly symptomatic herpes genitalis [98]. Its use is not licensed in pregnancy [99]. In case of oral use ACV bioavailability is very low, about $15-30 \%$ [82]. Valacyclovir is a prodrug ester form of ACV, with significantly better oral bioavailability [100]. It has a standard use for herpes genitalis with an efficient repressor effect for recurrent infections, but not licensed in treatment for immunosuppressed patients and children [100].

Penciclovir and famciclovir has a similar action than ACV. Famciclovir is an inactive diacetyl ester prodrug of PCV. In oral use famcyclovir transform to PCV [101]. A major advantage of these drugs compared to ACV is that their elimination time is much longer [102]. They can be used to treat herpes genitalis, along with ACV and valacyclovir [103].

\subsection{Drug-resistance of herpes simplex virus}

Several antiviral agents can be used for the treatment of HSV infections, however the emerging of drug-resistant HSV mutants poses a constant treatment concern, especially in the immunecompromised population [104]. Resistance can be acquired by at least four mechanisms. The resistant strain could (1) lack TK activity or has decreased activity, (2) down-regulate the expression of the viral TK, (3) alter the substrate specificity of the viral TK protein and (4) alter the substrate specificity of the viral DNA polymerase [105] [106]. As an example, it was shown that a single amino acid change in HSV-2 TK has significantly increased ACV/PCV resistance [107]. The global prevalence of ACV-resistant HSV infections was reported between $2.5 \%$ and $10 \%$ for immune-compromised patients [108]. Strains resistant to ACV are almost always crossresistant to other TK-dependent drugs such as PCV and famciclovir [105]. The management of ACV- or PCV-resistant HSV infections includes the use of the pyrophosphate analogue foscarnet and the nucleotide analogue cidofovir [96] [109]. Cidofovir is a monophosphate nucleotide analog and was the first approved nucleotide analog for clinical use against ACV resistant HSV. The viral TK is not required for the first phosphorylation, therefore its action is not selective. 
Interestingly, acyclovir-resistant strains became sensitive to acyclovir following cidofovir therapy [109]. At present, only the intravenous formulation of cidofovir is commercially available, causing nephrotoxicity manifested as proteinuria (12\%), and increased serum creatinine level (5\%) and neutropenia (15\%) [110].

\subsection{Novel antiviral treatments of herpes simplex virus}

A broad spectrum of antiviral compounds such as rhodanine and thiobarbituric derivatives display antiviral activity against different enveloped viruses including the HSV-2 acyclovir resistant strains [111] [112]. Extracts of medical plants and their natural products could offer a library of chemical compounds with potential antiviral properties. In vitro screening of the ethanol extracts of Veronica persica Poir showed a dose-dependent antiviral activity against intracellular and extracellular HSV [113]. Moreover, the extracts synergistic antiviral activity in combination with ACV was also promising [113]. Essential oils from various aromatic medicinal plants are highly active against some viral infections, as an example: balm oil, tea tree oil and peppermint oil demonstrated a significant anti-HSV-activity in vitro [114]. These essential oils are also highly active against ACV-resistant HSV strains [114]. In clinical studies, tea tree oil has been shown to possess anti-HSV, anti-inflammatory and pain-relieving properties, as well as accelerated the healing process [114]. Besides plant extracts, various other studies identified promising extracts, fractions and pure compounds as potential anti-herpetic agents derived from microorganisms, marine organisms, fungi and animals [115]. Griffithsin is a marine algal lectin that exhibits broadspectrum antiviral activity. There are promising studies on the novel drug class, which are targeting the helicase-primase complex [116]. These viral DNA helicase blockers are still undergoing testing and development [116] [117] [118]. There are also trials for anti HSV vaccines, but an effective vaccine has not been developed yet [119] [120].

We should also remember that the current antiviral drugs do not cure HSV infections. Antiviral treatment decreases the severity and length of the outbreaks and helps the sores heal faster, keeps new sores from forming and decreases pain. HSV accomplishes latency between reactivations and an ideal novel anti-HSV drug also should interfere with the latent state of viral replication. 


\section{AIMS OF THIS STUDY}

\section{AIM 1:}

In vitro and in vivo monitoring of the effect of hydroxyethyl cellulose a major gelling agent of vaginal gels on C. trachomatis growth.

\section{AIM 2:}

Identification of murine defense genes that could be involved in the elimination of the murine Chlamydia strain and murine genes that could be effective against the human Chlamydia strains.

\section{AIM 3:}

To identify novel antiviral compounds extracted from the berry of sea buckthorn, Elaeagnus rhamnoides (E. rhamnoides) and from Rumex aquaticus (R. aquaticus). 


\section{MATERIALS AND METHODS}

\subsection{Cell lines}

In this study HeLa 229 (ATCC, Manassas, VA, USA), McCoy (ECACC, London, UK) and Vero cells (ATCC) were used. The cells were cultivated on 96-well plates (Sarstedt, Nümbrecht, Germany) chamber slides (Thermo Scientific ${ }^{\mathrm{TM}}$ Nunc $^{\mathrm{TM}}$ Lab-Tek $^{\mathrm{TM}}$, Waltham, MA, USA) and round cover glass (Thermo Scientific ${ }^{\mathrm{TM}}$ VWR $^{\mathrm{TM}}$ Menzel- Gläser, Magna Park, England).

\subsection{Chlamydia strains}

C. trachomatis (serovar D, UW3/CX reference strain, and serovar E strain DK20; ATCC) and $C$. muridarum strain Nigg [74] were propagated in McCoy cells. C. pneumoniae CWL029 strain ATCC was propagated in HEp-2 cells (ATCC), as described earlier [121]. After partial purification and concentration the EBs were aliquoted in sucrose-phosphate-glutamic acid buffer (SPG) and stored at $-80{ }^{\circ} \mathrm{C}$ until use [122]. McCoy cell monolayer were infected with the different Chlamydia strain and their titers was determined by indirect immunofluorescence test.

\subsection{Extracted compounds from Elaeagnus rhamnoides and Rumex aquaticus}

The extracted compounds were provided by our cooperation partner, Judit Hohmann (Interdisciplinary Centre of Natural Products, University of Szeged, 6720 Szeged, Hungary). Compound 1 (6,9-dihydroxy-1-ox-14-noreudesm-5,7,9 triene), compound 2 (2-hydroxy-7isopropyl-1-methoxy-4-methyl-1,4-naphthoquinone), compound 3 (methoxy-substituted phenylpropane dimer) and compound 4 (caulexin C) were extracted from the berry of $E$. rhamnoides. Compound 5 (musizin), compound 6 (musizin-8-O-glucoside) compound 7 (torachrysone-8-O-glucoside) and compound 8 (2-methoxystipandron) are substituted naphtalenes, extracted from $R$. aquaticus. 


\subsection{Preparation of hydroxyethyl cellulose solution in vaginal simulant buffer}

The aqueous solution of HEC (European Pharmacopoeia 9.0 [123] quality, Molar Chemicals, Halásztelek, Hungary) were made by dissolving $30 \mathrm{mg}$ of the HEC polymers in $1 \mathrm{ml}$ of physiological salt solution $(0.9 \% \mathrm{w} / \mathrm{v} \mathrm{NaCl})$, following, an 2-fold dilutions in the vaginal simulant. The applied HEC concentration range was between $1.5-0.023 \%$ w/v. The compound for $1 \mathrm{~L}$ vaginal simulant buffer were of $\mathrm{NaCl} 3.51 \mathrm{~g} / \mathrm{l}$; $\mathrm{KOH} 1.40 \mathrm{~g} / \mathrm{l} ; \mathrm{Ca}(\mathrm{OH}) 20.222 \mathrm{~g} / 1$; bovine serum albumin $0.018 \mathrm{~g} / \mathrm{l}$; lactic acid $2.00 \mathrm{~g} / \mathrm{l}$; acetic acid $1.00 \mathrm{~g} / \mathrm{l}$; glycerol $0.16 \mathrm{~g} / \mathrm{l}$; urea $0.4 \mathrm{~g} / \mathrm{l}$; glucose $5.0 \mathrm{~g} / \mathrm{l}$ which were dissolved in distilled water [124]. The $\mathrm{pH}$ of the vaginal simulant was adjusted to a $\mathrm{pH} 4.2$ or $\mathrm{pH} 7.0$, with $\mathrm{NaOH}$ and $\mathrm{HCl}$ solutions.

\subsection{Investigation of impact of hydroxyethyl cellulose on Chlamydia trachomatis serovars $D$ and $E$ growth in HeLa cells}

HeLa 229 cells were placed into 96-well plates at a density of $4 \times 10^{4}$ cells/well in $100 \mu 1$ of minimal essential medium (MEM) with Earle's salts supplemented with 10\% heat-inactivated fetal bovine serum, $2 \mathrm{mmol} / \mathrm{l}$ L-glutamine, 1x MEM vitamins, 1x non-essential amino acids, $0.005 \%$ Na-pyruvate, $25 \mu \mathrm{g} / \mathrm{ml}$ gentamycin, $1 \mathrm{~g} / \mathrm{ml}$ fungizone. The next day at $90 \%$ confluence of the cells were subjected to the infection after twice washing with $100 \mu \mathrm{l} /$ well with phosphate buffer saline (PBS) pH 7.4. Before the infection, the inoculum of EBs was pre-incubated in HEC 2-fold dilution (concentration range 1.5-0.023\% w/v) with C. trachomatis D and E strains at $\mathrm{pH}$ 4.2 and $\mathrm{pH}$ 7.0. In the control group vaginal simulant buffer at $\mathrm{pH} 4.2$ and $\mathrm{pH} 7.0$ was alone preincubated with $\mathrm{EBs}$ for $1 \mathrm{~h} 37^{\circ} \mathrm{C}, 5 \% \mathrm{CO}_{2}$ as well. The pre-incubated inoculum of all groups were suspended in $0.5 \%(\mathrm{w} / \mathrm{v})$ glucose medium and added to the cell layers. The infection was accomplished by incubating for $60 \mathrm{~min}$ at $37^{\circ} \mathrm{C}, 5 \% \mathrm{CO}_{2}$ without centrifugation. Following the infection, the cells were washed twice with PBS, and a culture medium containing $0.1 \mu \mathrm{g} / \mathrm{ml}$ cycloheximide was added. After the 48 hour incubation, the medium was removed from the cell monolayer, washed twice with PBS and $100 \mu$ Milli-Q (MQ) (Millipore, Billerica, MA, USA) water was added to the cells. The cell lysis were accomplished by two freeze-thaw cycles; cells with the supernatant were subjected to quick freezing $\left(-80^{\circ} \mathrm{C}, 15 \mathrm{~min}\right)$ and a quick thawing on a plate shaker. The cell lysates with the supernatant were thoroughly mixed including the edges of the wells using a multichannel pipette. The mixed lysates were used as a template for the qPCR analysis. 


\subsection{Monitoring the growth of Chlamydia trachomatis serovars $D$ and $E$ by direct quantitative PCR}

After the accomplished cell lysis, the mixed lysates were used as a template in the qPCR [125]. The quantitative PCR (qPCR) was performed using the Bio-Rad CFX96 real time system. The SsoFast EvaGreen qPCR Supermix (Bio-Rad, Hercules, CA, USA) master mix and $C$. trachomatis pykF gene specific primer pair were used [79]. The primer sequences were the following: $\quad p y k F-F$ : 5'-GTTGCCAACGCCATTTACGATGGA-3', and pykF-R: 5'TGCATGTACAGGATGGGCTCCTAA-3'. $5 \mu$ l SsoFast EvaGreen supermix, $1-1 \mu$ forward and reverse primers (10 pmol each), $1 \mu \mathrm{l}$ template and $2 \mu \mathrm{l}$ MQ water was the consistent of the PCR mixture with a $10 \mu \mathrm{l}$ final volume. $40 \mathrm{PCR}$ cycles of $20 \mathrm{~s}$ at $95{ }^{\circ} \mathrm{C}$ and 1 min at $64{ }^{\circ} \mathrm{C}$ were performed with a $10 \mathrm{~min}$ at $95{ }^{\circ} \mathrm{C}$ polymerase activation for the first step. The fluorescence intensity was measured at the end of the annealing-extension step. The melting curve analysis was used to get the specificity of amplification. For each PCR, the cycle threshold $(\mathrm{Ct})$ corresponding to the cycle where the amplification curve crossed the base line was determined. To evaluate the statistical differences between the samples ( 3 biological replicates for each condition) Student's $t$ test was used.

\subsection{Monitoring the growth of Chlamydia trachomatis strains D and E by chamber slide method}

Chamber slides with 16 wells consisting of a removable, plastic chamber attached to a specially treated standard glass slide were used to culture HeLa cells for infection with Chlamydia. The slides were treated with $100 \mu \mathrm{l} /$ well $0.01 \%$ poly-L-lysine (Pharmacia LKB, Biotechnology AB, Uppsala, Sweden) at room temperature (RT) for 15-20 min in order to optimize cell attachment. The cells were transferred into the wells of the chamber slides at a density of $4 \times 10^{4}$ cells/well in $100 \mu \mathrm{l}$ of MEM culture medium (see above). The slides were incubated for $1 \mathrm{~h}$ at room temperature in order to reduce the edge effect [126] [127] and then overnight at $37^{\circ} \mathrm{C}$ under a 5\% $\mathrm{CO}_{2}$ atmosphere to obtain a $90 \%$ confluent cell layer. The infections were accomplished in way as was it described above (Investigation of impact of HEC on Chlamydia strains D and E growth in HeLa cells) except in this case were used only the highest concentrations for all groups. Briefly the pre-incubated EBs with HEC at pH 4.2 and 7.0 and with vaginal simulant at $\mathrm{pH} 4.2$ and $\mathrm{pH}$ 7.0 were added to the cells. The infection was cultivated by incubating for $60 \mathrm{~min}$ at $37{ }^{\circ} \mathrm{C}, 5 \%$ $\mathrm{CO}_{2}$ without centrifugation. Following the infection, the cells were washed twice with PBS, and 
a culture medium containing $0.1 \mu \mathrm{g} / \mathrm{ml}$ cycloheximide was added. After the 48 hour incubation cells were fixed for immunofluorescence staining. After removing the culture medium from the slides, the cells were washed twice with PBS $(100 \mu \mathrm{l} /$ well). Then, the chamber structure was detached from the slides and the cells were fixed with precooled $100 \%$ acetone for $10 \mathrm{~min}$ at -20 ${ }^{\circ} \mathrm{C}$. Anti-chlamydia LPS antibody (AbD Serotec, Oxford, United Kingdom) was labeled with Alexa-647, and a 1:200 dilution was used for the detection of chlamydial inclusions. After incubation for $1 \mathrm{~h}$ at $37^{\circ} \mathrm{C}$, the cells were washed three times with PBS for 7 min each time and finally with distilled water. Fluorescence signals were analyzed with an Axon GenePix Personal 4100A DNA chip scanner and GenePix Pro (version 6.1) software (Molecular Devices, Sunnyvale, CA) as published earlier [128]. In this investigation 4 biological replicates for each condition were evaluated.

\subsection{Investigating the in vivo effect of hydroxyethyl cellulose on growth of Chlamydia trachomatis serovar D}

To monitor the effect of HEC in vivo, 6-8 week old female BALB/c mice were treated s.c. with $2.5 \mathrm{mg}$ medroxyprogesterone acetate (Pfizer, Budapest, Hungary) 1 week before infection. Mice were inoculated intra-vaginally with $1 \times 10^{5}$ inclusion forming units (IFU) of $C$. trachomatis serovar D mixed with HEC (1.5\% w/v) and as a control group without HEC. After 3 day post infection cervicovaginal microenvironment was subjected for investigation by harvesting cervicovaginal washes from mice. The mice were intra-vaginally washed with $100 \mu \mathrm{l}$ SPG. Afterward the samples were subjected to two freeze-thaw cycles, freezing at $-80^{\circ} \mathrm{C}, 45 \mathrm{~min}$ and thawing on a plate shaker at the room temperature. Following the last thaw step the recoverable IFU from samples was evaluated by using traditional immunofluorescence microscopy [129]. McCoy cells were seeded on glass slips in 24-well plate day before the infection. $100 \mu$ of each sample was suspended in $1 \mathrm{~mL} 0.5 \%(\mathrm{w} / \mathrm{v})$ glucose medium added to the McCoy cell monolayer. Infection was accomplished by centrifugation for 1 hour with $600 \mathrm{~g}$. Following the infection, the cells were washed twice with PBS, and a culture medium containing $0.1 \mu \mathrm{g} / \mathrm{ml}$ cycloheximide was added. After the 48 hour incubation cells were fixed by removing the culture medium, washing twice with PBS (1 mL/well) and adding precooled $100 \%$ acetone for $10 \mathrm{~min}$ at $-20{ }^{\circ} \mathrm{C}$. Following the fixation, inclusions were stained with monoclonal anti-Chlamydia LPS antibody (AbD Serotec, Oxford, UK) and FITC-labeled anti-mouse IgG (Sigma). The number of the recoverable Chlamydia inclusions was evaluated by using traditional immunofluorescence microscopy [129]. 


\subsection{Infection of BALB/c and C57BL/6 mice with Chlamydia pneumoniae and Chlamydia muridarum and processing of the lung tissues}

Pathogen-free 6-week-old female BALB/c mice were obtained from the Charles River Laboratories (Hungary), C57BL/6 mice obtained from BRC Animal House (Szeged, Hungary). The mice were maintained under standard husbandry conditions at the animal facility of the Department of Medical Microbiology and Immunobiology, University of Szeged, and were provided with food and water ad libitum. Before infection, the mice were mildly sedated with an intraperitoneal injection of $200 \mu \mathrm{l}$ of sodium pentobarbital $(7.5 \mathrm{mg} / \mathrm{ml})$; they were then infected intra-nasally with 4 x $10^{5}$ IFU C. pneumoniae (BALB/c) or $1 \times 10^{3}$ IFU of $C$. muridarum (BALB/c and C57BL/6) in $20 \mu \mathrm{l} \mathrm{SPG}$ buffer. Control mice were treated with $20 \mu \mathrm{l}$ SPG buffer only. The mice were anaesthetized and sacrificed 7 days after infection. The lungs were removed and homogenized with acid-purified sea sand (Sigma, St.Louis, MO, USA). Half of each homogenized lung was processed for total RNA extraction, and the other half was suspended in $1 \mathrm{ml}$ of SPG for the detection of viable Chlamydia and to test the quantity of the tryptophan derivates. The lungs of three mice from both groups were fixed in $10 \%$ neutral buffered formalin solution (Sigma) for histopathological evaluation. All experiments were approved by the Animal Welfare Committee of the University of Szeged and conform to the Directive 2010/63/EU of the European Parliament.

\subsection{Culturing of Chlamydia pneumoniae and Chlamydia muridarum from BALB/c mouse lungs}

Homogenized lungs from individual mice were centrifuged (10 min, 400g), serial dilutions of the supernatants were inoculated onto McCoy cell monolayers and centrifuged ( $1 \mathrm{~h}, 800 \mathrm{~g})$. After 48$\mathrm{h}$ incubation the cells were fixed with acetone and stained with monoclonal anti-Chlamydia LPS antibody (AbD Serotec,) and FITC-labeled anti-mouse IgG (Sigma). The number of the recoverable Chlamydia inclusions was counted under a UV microscope and expressed as IFU/lung. 


\subsection{Inhibition of indoleamine 2,3-dioxygenase by 1-methyl-DL-tryptophan in}

BALB/c mice

Seven days before infection with $C$. muridarum the drinking water of 8-weeks-old female mice $(\mathrm{n}=4)$ was changed to that containing $2 \mathrm{mg} / \mathrm{ml}$ IDO inhibitor 1-methyl-DL-tryptophan (1-MT) (Sigma), dissolved in $10 \mathrm{mmol} / \mathrm{l} \mathrm{NaOH}$ supplemented with Stevia sweetener. Control mice $(\mathrm{n}=4)$ received the Stevia-sweetened drinking water with $10 \mathrm{mmol} / \mathrm{l} \mathrm{NaOH}$ without 1-MT. The solution was delivered in autoclaved water bottles, protected from light, and changed every other day. The infection of mice and the estimation of recoverable viable $C$. muridarum from the lungs at 7 day post infection were carried out as described previously.

\subsection{Total RNA extraction and cDNA synthesis from Chlamydia infected and uninfected BALB/c and C57BL/6 mouse lungs}

Total RNA was extracted from homogenized lung tissues of $C$. muridarum infected mice BALB/c $(\mathrm{n}=3)$ and C57BL/6 mice $(\mathrm{n}=5)$, C. pneumoniae infected BALB/c mice $(\mathrm{n}=3)$ and uninfected controls ( $\mathrm{n}=3$ ) with Tri Reagent according to the manufacturer's protocol (Sigma). Total RNA quantity (OD260) and purity (OD260/280) were measured by a NanoDrop spectrophotometer (Thermo Scientific, Waltham, MA, USA).

\subsection{3. cDNA library preparation and sequencing}

cDNA library for RNA-Seq was generated from $1 \mu \mathrm{g}$ total BALB/c lung RNA using TruSeq RNA Sample Preparation Kit (Illumina, San Diego, CA, USA) according to the manufacturer's protocol. Single read 50bp sequencing run was performed on Illumina HiScan SQ instrument (Illumina). CASAVA software was used for pass filtering and demultiplexing process. Sequenced reads were aligned to Mus musculus mm10 genome version using TopHat and Cufflinks algorithms and bam files were generated. The RNA sequencing, identification of differentially expressed genes, collection and comparison of IDO1 and IDO2 raw data were performed by Szilárd Poliska (University of Debrecen, Biochemistry and Molecular Biology). 


\subsection{Statistical and functional analysis of RNA-sequencing data}

StrandNGS software (Agilent, Santa Clara, CA, USA) was used for the statistical analysis of RNA-sequencing (RNA-Seq) data. The aligned bam files were imported and DESeq algorithm was used in the quantification step to generate normalized gene expression data. Differentially expressed genes between $C$. muridarum infected lung samples $(\mathrm{n}=3)$ and controls $(\mathrm{n}=3)$ were determined using the Student's t-test combined with Benjamini-Hochberg FDR for multiple testing correction. Statistical significance was defined as $P_{\text {Benjamini-Hochberg }}<0.05$. Library preparations, sequencing and data analysis were performed by UD-GenoMed Kft. and the Genomic Medicine and Bioinformatics Core Facility of University of Debrecen, Debrecen, Hungary. Large scale functional analysis of differentially expressed genes were performed by the Voronto software [130]. The Voronto method identifies the Gene Ontology terms and KEGG pathways that contain significantly enriched differentially expressed genes. Voronto software uses the so-called Voronoi tessallation to map ontology terms or pathways into a map-like structure. The cells of the map are the ontology terms, the closer terms being located closer to each other. Terms with a common ancestor are surrounded by a thicker line.

\subsection{Quantitative PCR validation of the IDO1 and IDO2 RNA-Seq data}

For quantitative PCR (qPCR) $1 \mu \mathrm{g}$ of total RNA was reverse transcribed using the Maxima Reverse Transcriptase according to the manufacturer's protocol with random hexamer priming (Thermo Fisher Scientific Inc. Waltham, MA, USA). qPCR was performed in a Bio-Rad CFX96 real-time system. The qPCR was performed with the SsoFast EvaGreen qPCR Supermix (BioRad, Hercules, CA, USA) master mix and the murine specific primer pairs IDO1: 5'GCTTCTTCCTCGTCTCTCTATTG-3'， 5'-TCTCCAGACTGGTAGCTATGT-3'; IDO2: 5'CCTGGACTGCAGATTCCTAAAG-3'; 5'-CCAAGTTCCTGGATACCTCAAC-3'; beta-actin: 5'-TGGAATCCTGTGGCATCCATGAAAC-3', 5'-TAAAACGCAGCTCAGTAACAGTCCG-

3'. To check the amplification specificity, the qPCR was followed by a melting curve analysis. Threshold cycles $(\mathrm{Ct})$ were calculated for IDO1, IDO2 and beta-actin genes, and the normalized gene expressions were calculated by the $\Delta \mathrm{Ct}$ method $\left(\mathrm{Ct}_{\mathrm{IDO} 1}-\mathrm{Ct}_{\text {actin }}\right.$ or $\left.\mathrm{Ct}_{\mathrm{IDO} 2}-\mathrm{Ct}_{\text {actin }}\right)$. Statistical comparison of qPCR data was performed by comparing the $\Delta \mathrm{Ct}$ values of uninfected and infected lung samples $(\mathrm{n}=3)$ by using the Student's t-test as described earlier [131]. 


\subsection{IDO1 and IDO2 immunohistochemistry of Chlamydia pneumoniae and}

\section{Chlamydia muridarum infected and uninfected BALB/c mouse lungs}

IDO1 and IDO2 immunohistochemistry was performed on the lungs that were used in the gene expression studies. Macroscopically inflamed lung sections and control lungs were cut and fixed in $10 \%$ formalin (Sigma). Fixed samples were cut into $4 \mu \mathrm{m}$ sections. Tissue sections were first deparaffinized, followed by antigen retrieval and inhibition of endogen peroxidases using the EnVision FLEX Peroxidase-blocking reagent (Dako, Carpinteria, CA, USA). IDO immunohistochemistry was performed with a goat polyclonal anti-IDO1 antibody (Sigma) and a rabbit polyclonal anti-IDO2 antibody (Bioss, Woburn, MA, USA) followed by HRP-conjugated anti-goat rabbit (Dako) and anti-rabbit goat secondary antibodies (Dako) respectively. The histology and IDO1-2 immunohistochemistry were performed by László Tiszlavicz (University of Szeged, Department of Phatology)

\subsection{Measurement of tryptophan and kynurenine concentrations in Chlamydia pneumoniae and Chlamydia muridarum infected and uninfected BALB/c and C57BL/6 mouse lung tissues}

Infected and control BALB/c and C57BL/6 mouse lung tissues were homogenized with sterile sand (Sigma), and dissolved in $700 \mu \mathrm{l}$ xPBS. The samples were sonicated $2 \times 1$ min, vortexed and centrifuged at $500 \mathrm{~g}$ for 5 minutes. $20 \mu \mathrm{l}$ of internal standard (3-nitro L-tyrosine (3NLT) $(2 \mu \mathrm{M})$ in $2.5 \mathrm{w} / \mathrm{w} \%$ perchloric acid was added to $480 \mu \mathrm{l}$ supernatant and mixed with $500 \mu \mathrm{l}$ perchloric acid. The samples were subsequently centrifuged at $12000 \mathrm{~g}$ for $10 \mathrm{~min}$ at $4{ }^{\circ} \mathrm{C}$, and the supernatants were collected for measurement. The tryptophan and kynurenine concentrations of the samples were quantified as described previously with slight modifications [132]. In the highperformance liquid chromatography (HPLC) analysis, the peak area responses were plotted against the corresponding concentration, and the linear regression computations were carried out using the least squares method with the R software package [133]. The kynurenine and tryptophan HPLC measurements were performed by László Vécsei and Gábor Veres (University of Szeged, Department of Neurology). 


\subsection{Herpes simplex virus-2 strains}

The HSV-2 strain (donated by Dr. Ilona Mucsi, University of Szeged, Szeged, Hungary) was grown in Vero cells and the titer was determined in the same cell line by using the plaque titration method [134].

\subsection{3-(4,5-Dimethylthiazol-2-yl)-2,5-diphenyltetrazolium bromide (MTT) assay}

MTT assay was carried out to identify the highest non-toxic concentration of compounds 1-3 and 5-8 with potential anti-viral activity. Vero cells were transferred into the wells of the 96-well plate (Sarstedt, Nümbrecht, Germany) at a density of $6 \times 10^{4}$ cells/well in $100 \mu 1$ of MEM with Earle salts supplemented with 10\% heat-inactivated fetal bovine serum (FBS) (Gibco; Germany), 2 mmol/1 L-glutamine, 1x MEM vitamins, 1x non-essential amino acids, 0.005\% Na-pyruvate, 25 $\mu \mathrm{g} / \mathrm{ml}$ gentamycin, $1 \mu \mathrm{g} / \mathrm{ml}$ amphotericin-B (SIGMA, St. Louis, MO, USA). The plates were incubated for $1 \mathrm{~h}$ at room temperature (RT) and then overnight at $37{ }^{\circ} \mathrm{C}, 5 \% \mathrm{CO}_{2}$. Following day, the medium was removed and fresh medium complemented with 2-fold serial dilutions of all compounds was added to three parallel wells for each concentration. After $24 \mathrm{~h}$ the $10 \mu \mathrm{l}$ of the MTT (SIGMA) labelling reagent (final concentration $0.5 \mathrm{mg} / \mathrm{ml}$ ) was added to each well and the plate was incubated for $4 \mathrm{~h}$ at $37^{\circ} \mathrm{C}, 5 \% \mathrm{CO}_{2}$. After the incubation, $100 \mu \mathrm{l}$ of the lysis solution $(10 \% \mathrm{SDS}$ in $1 \mathrm{~N} \mathrm{HCl}$ ) was added to each well and the plate was allowed to stand overnight in the incubator at $37{ }^{\circ} \mathrm{C}, 5 \% \mathrm{CO}_{2}$. The next day, the optical density of the wells was measured by a microtiter plate reader (Labsystems Multiskan Ex 355, Thermo Fisher Scientific, Waltham, MA USA). The absorbance of the formazan product was measured at $540 \mathrm{~nm}$ [135].

\subsection{Assays for testing antiviral activity}

The antiviral activity of sea buckthorn compounds was investigated in Vero cells. Cells were seeded in 96-well plates and were infected with HSV-2 at MOI of 0.01. After a $1 \mathrm{~h}$ adsorption period, the inoculum was removed, the cultures were washed twice, and culture medium containing the plant compounds in different concentrations was added. After a 24-hour incubation period, the cultures were washed with PBS, and finally $100 \mathrm{~mL} \mathrm{MQ}$ was added to the cells. After, two quick freeze-thaw cycle, the cells were subjected to lysis. 


\subsection{Measuring antiviral activity by direct quantitative PCR}

DNA release from the infected cells was achieved by two freeze-thaw cycles. $1 \mathrm{~mL}$ of the lysates were used directly in a qPCR assay. Each antiviral test was performed in 3 parallel wells. The qPCR assay was performed using a Bio-Rad CFX96 real time system, as described earlier [136]. Briefly, a HSV-2 gD2 gene specific primer pair was applied during the qPCR process. The primer sequences were the following: gD2: 50-TCA GCG AGG ATA ACC TGG GA-30, 50-GGG AGA GCG TAC TTG CAG GA-3'. The qPCR mixture consisted of $5 \mathrm{~mL}$ SsoFast ${ }^{\mathrm{TM}}$ EvaGreen ${ }^{\circledR}$ Supermix (Bio-Rad, Hercules, CA, USA), 1-1 mL of forward and reverse primers $(10 \mathrm{pmol} / \mathrm{mL}$ each) and $1 \mathrm{~mL}$ template, and $2 \mathrm{~mL}$ MQ water was added to get a final volume of $10 \mathrm{~mL}$. After a 10 -min polymerase activation step at $95{ }^{\circ} \mathrm{C}, 40 \mathrm{PCR}$ cycles of $20 \mathrm{~s}$ at $95{ }^{\circ} \mathrm{C}$ and $1 \mathrm{~min}$ at $64{ }^{\circ} \mathrm{C}$ were performed. Fluorescence intensity was detected at the end of the annealing-extension step. The specificity of amplification was confirmed by melting curve analysis. For each PCR, the cycle threshold $(\mathrm{Ct})$ corresponding to the cycle where the amplification curve crossed the base-line was determined.

\subsection{Determination of TCIDso by the virus yield reduction technique}

The virus yield in the supernatants of infected and plant compound-treated Vero cells was determined by the traditional dilution method. Vero cells $(60,000$ cells/well) were seeded onto 96-well flat-bottomed plates and cultivated for $24 \mathrm{~h}$ at $37 \mathrm{C}$ at $5 \% \mathrm{CO}_{2}$ to produce a semi-confluent monolayer. Then the growth medium was removed and 10-fold dilutions of HSV-2 in the absence of the test compound (virus control), as well as compound-treated HSV-2-infected cell supernatants were added in quadruplicate, and plates were incubated at $37 \mathrm{C}$ until typical cytopathic effect (CPE) was visible. After $48 \mathrm{~h}$, the CPE of the virus was examined using an inverted microscope, and virus titers were estimated according to the Reed-Muench method, expressed as $\mathrm{TCID}_{50} / \mathrm{mL}$. The test compounds' antiviral activity was measured as the reduction of viral titer $\left(\log _{10}\right)$ in the presence of each compound, compared to the virus titer of the control sample. 


\section{RESULTS}

AIM 1: In vitro and in vivo monitoring of the effect of hydroxyethyl cellulose a major gelling agent of vaginal gels on $C$. trachomatis growth.

\subsection{Monitoring the impact of hydroxyethyl cellulose on the growth of Chlamydia trachomatis serovar D and E by quantitative PCR}

To better mimic the cervicovaginal environment, we used the vaginal simulant to dilute HEC and incubate $C$. trachomatis EBs. The $\mathrm{pH}$ of the vaginal simulant was adjusted to a $\mathrm{pH} 4.2 \mathrm{or} \mathrm{pH} 7.0$ to mimic the normal and elevated $\mathrm{pH}$ of the cervicovaginal tract. Figure 1A shows a HEC concentration-dependent enhancement of chlamydial growth after the pre-incubation of $C$. trachomatis EBs in $\mathrm{pH} 4.2$ vaginal fluid measured by qPCR 48 hours post infection. The $C$. trachomatis serovar D maximum growth increase was 23.7 fold at the maximal $1.5 \%$ w/v HEC concentration, and a noticeable, but non-significant growth enhancement tendency could be detected up to a concentration of $0.188 \%$ w/v HEC. HEC at $\mathrm{pH} 7.0$ enhanced the chlamydial growth significantly with a 13.8 fold growth increase at a concentration of $1.5 \% \mathrm{w} / \mathrm{v}$ (Figure $1 \mathrm{~B}$ ). Interestingly, in the case of $C$. trachomatis serovar E, the maximum growth increase (22.25 and 26.1 fold at $\mathrm{pH} 4.2$ and $\mathrm{pH} 7.0$ respectively) was observed at the second highest HEC concentration $(0.75 \%$ w/v) at both $\mathrm{pH} 4.2$ and $\mathrm{pH} 7.0$ indicating a different HEC-EB interaction between the serovars (Figure 1A-B).

\subsection{Monitoring the impact of hydroxyethyl cellulose on the growth of Chlamydia trachomatis strains D and E by chamber slide method}

To validate the qPCR results, we performed the automatic Chlamydia inclusion counting using the ChlamyCount measuring system, at $\mathrm{pH} 4.2 \mathrm{or} \mathrm{pH} 7.0$ at $1.5 \% \mathrm{w} / \mathrm{v}$ and $0.75 \% \mathrm{w} / \mathrm{v} \mathrm{HEC}$ concentrations for serovar D and serovar E, respectively. Inclusion counts showed similar, albeit lower growth enhancement than the chlamydial genome measurements by qPCR with a 5.9-6.5 fold increase for serovar D and 5.95-6.05 fold increase for serovar E (Figure 1C). This difference is likely due to the fact, that ChlamyCount measures the chlamydial inclusion number, while qPCR measures the bacterial genome content of the inclusions. 
A

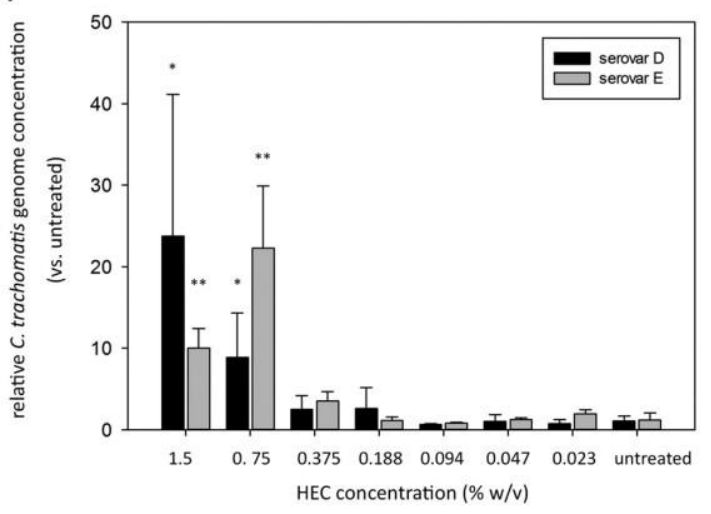

C

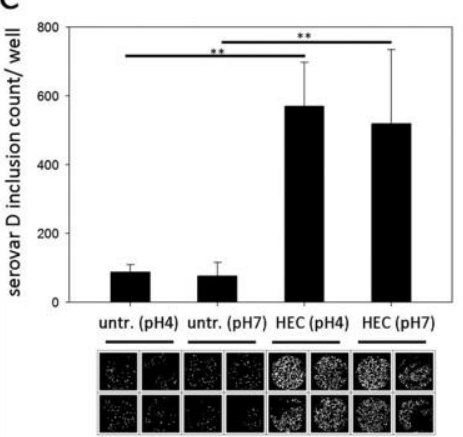

B

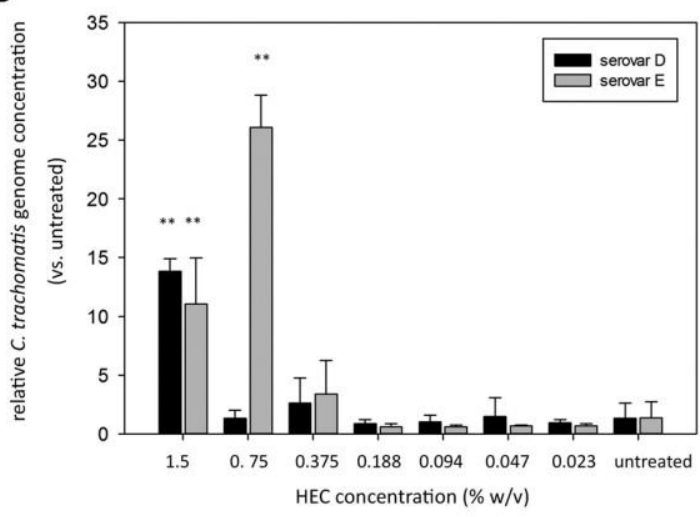

D
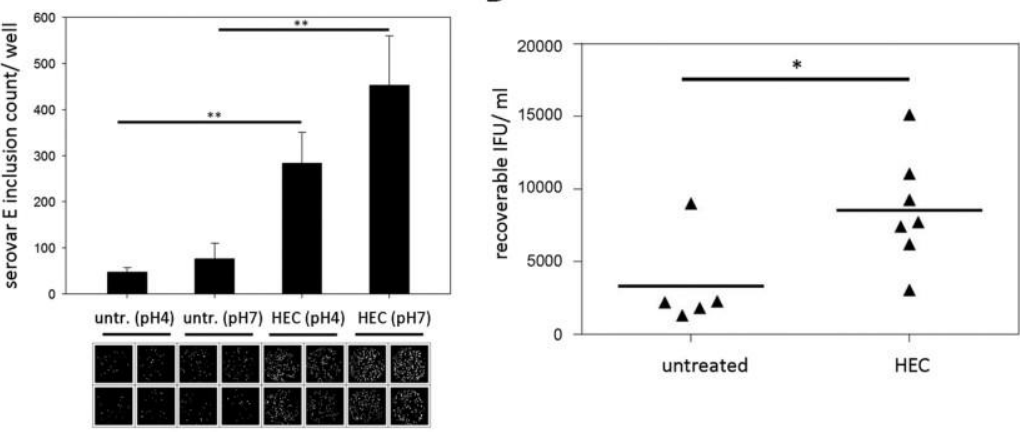

FIGURE 1. Impact of HEC on the growth of $C$. trachomatis serovars D and $\mathrm{E}$ in HeLa 229 cells in vitro at $\mathrm{pH}$ 4.2 (A) and $\mathrm{pH} 7$ (B). Bacterial genome copy numbers were measured by direct qPCR $(n=3)$. The qPCR data were validated by the ChlamyCount immunofluorescent automatic inclusion counting system $(n=4)$. (C) The images of the ChlamyCount-processed wells and the counted inclusion numbers.(D) Recoverable C. trachomatis serovar DIFU in cervicovaginal swab samples 3 days postinfection. Mice were infected intra-vaginally with $C$. trachomatis serovar D mixed with HEC $(1.5 \% \mathrm{wt} / \mathrm{vol})(n=7)$ or without HEC $(n=5)$. Data are means \pm standard deviations. *, $P<0.05$; **, $P<0.01$, according to Student's $t$-test.

\subsection{Investigating the in vivo effect of hydroxyethyl cellulose on growth of Chlamydia trachomatis serovar D}

The in vivo data also showed that HEC significantly increased the growth of $C$. trachomatis serovar D in the mouse genital tract, with a 2.57 fold enhancement 3 days post infection. It is important to note, that the chlamydial EBs were not pre-incubated with HEC before the infection, indicating an immediate growth enhancing effect of HEC in vivo. 
AIM 2: Identification of murine defense genes that could be involved in the elimination of the murine Chlamydia strain and murine genes that could be effective against the human Chlamydia strains.

\subsection{Chlamydia infection and Chlamydia-induced histopathology in BALB/c mouse lung tissues}

In our animal model different doses of the two Chlamydia strains were used (4 x $10^{5}$ IFU of $C$. pneumoniae and $1 \times 10^{3} \mathrm{IFU}$ of $C$. muridarum), based on the results of our former experiments [137][138] where the lower dose of the murine pathogen C. muridarum induced similar growth and histopathology than the human pathogen $C$. pneumoniae. Indeed, recoverable IFUs from the C. muridarum and C. pneumoniae infected BALB/c lungs were similar at 7 days post infection (Figure 2A). Both infections induced a lymphoid hyperplasia, with the interstitial accumulation of lymphoid, plasmocytoid cells and macrophages in the widened bronchus walls. The histology picture was consistent with the formation of inducible bronchus associated lymphatic tissue (iBALT). At this time of the infection, the presence of neutrophils were marginal, the major leukocyte populations were lymphocytes and macrophages (Figure 2B-C). Control lung tissue showed thin alveolar septa without the clear presence of inflammatory cells, but a small number of pulmonary macrophages could be detected (Figure 2D).

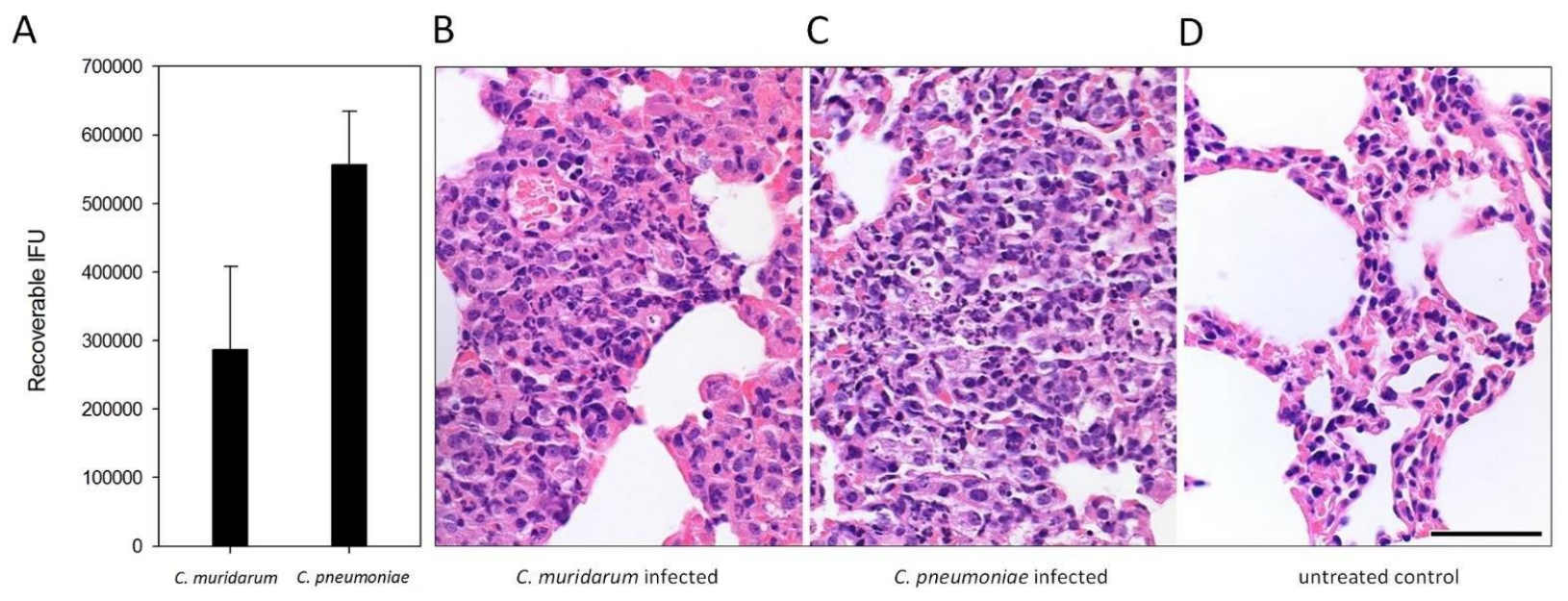

FIGURE 2. Chlamydia infection and Chlamydia-induced histopathology in BALB/c mouse lung tissues. Recoverable IFUs from C. muridarum infected and C. pneumoniae infected mouse lungs at 7 days post infection (A). Haematoxylin-eosin staining of $C$. muridarum infected (B), C. pneumoniae infected (C) and uninfected (D) lung tissues. Bar is $50 \mu \mathrm{m}$. 


\subsection{Impact of Chlamydia muridarum infection on the global gene expression of BALB/c mouse lung tissues}

To explore the global gene expression changes induced at the tissue level by the murine Chlamydia strain we performed an Illumina next generation RNA sequencing of mouse lung tissues infected with $C$. muridarum 7 days post infection. RNA-seq analysis revealed that 755 murine genes had a higher expression and 251 genes had a lower expression than the uninfected control. The extent of up-regulation and the number of up-regulated genes was higher (1.48-345 fold), than in the case of the down-regulated genes (1.5-14.36 fold). The most highly up-regulated gene was the CXCL11 (I-TAC), and several cytokines/ chemokines were among the highly upregulated genes including CXCL9 (MIG), CXCL10 (IP-10), CCL8 (MCP2), CCL2 (MCP1), IFNG, IL21, IL10, as well as already described defense genes IRG1, IIGP and IDO1. The most highly down-regulated gene was cDNA sequence BC023719 with a 14.36 fold of downregulation, and the functions of the most highly down-regulated genes were diverse.

Functional analysis of the differentially expressed genes using the Voronto method revealed several KEGG pathways that are related to Chlamydia-induced inflammation and anti-chlamydial innate and adaptive defense responses (Figure 3A). Several up-regulated genes rendered to celltype specific KEGG pathways such as T-cell, B-cell, NK-cell and hematopoietic cells-specific pathways indicating the influx of these leukocytes into the infected lung tissues. Indeed, increased expressions of various cell-specific genes and CD markers were detected such as T-cell markers $C D 3, C D 4, C D 5, C D 6, C D 7, C D 226$, B cells markers $C D 5, C D 7$, dendritic cell marker $C D 4, \mathrm{NK}-$ cell markers $C D 4, C D 7$, natural killer cell lectin-like receptors (KLRA2, KLRB1F, KLRK1, $K L R I 2, K L R C 2, K L R D 1)$ and macrophage-specific genes CD4, MSR 1 and MPEG1, indicating the influx and/or local proliferation of these cells in the infected lung tissue. Interestingly, when the upregulated genes were compared to the Mouse Gene Atlas gene expression database [139], the most significant overlap was detected with the LPS treated macrophage gene expression (data not shown), indicating the active involvement of activated macrophages in the Chlamydia-induced gene expression changes. We detected several highly upregulated chemokines, that could induce the cellular influx, including the lymphocyte chemokines CCL2 (MCP1), CCL5 (RANTES), CCL8 (MCP2), CXCL9 (MIG), CXCL10 (IP10), CXCL11 (I-TAC), the monocyte chemokines CCL2, CCL4 (MIP1B), CCL7 (MCP3), CCL8 (MCP2), CXCL10 and the neutrophil granulocyte chemokine CXCL5 (ENA78). Enhancing the effects of chemokines, various chemokine receptors 
A

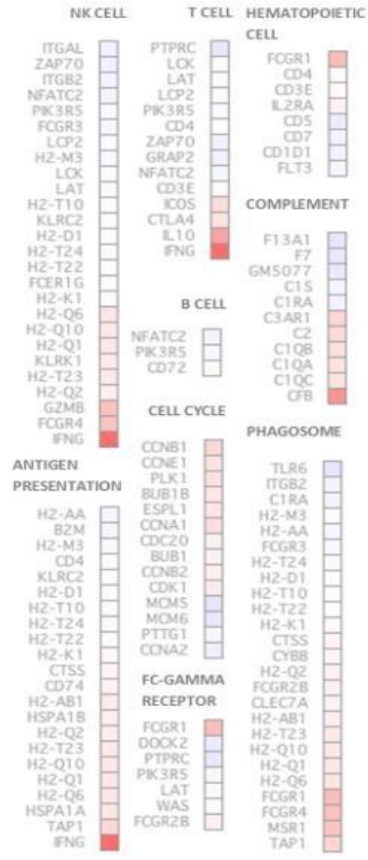

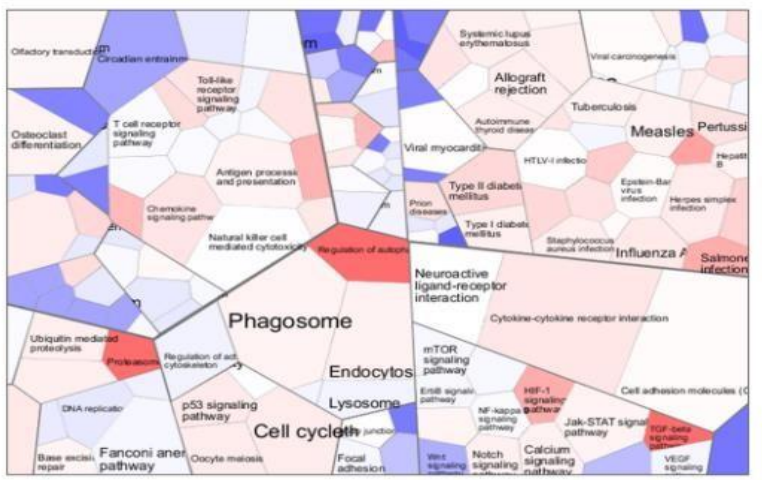

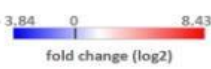

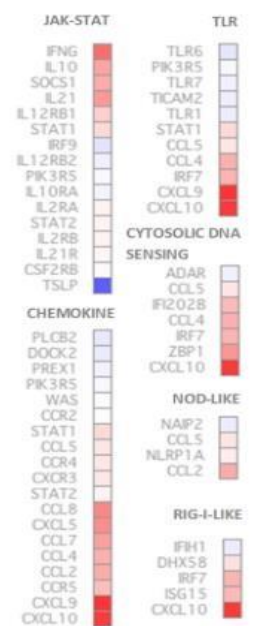

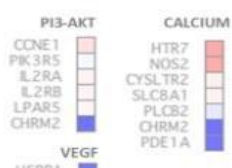

B

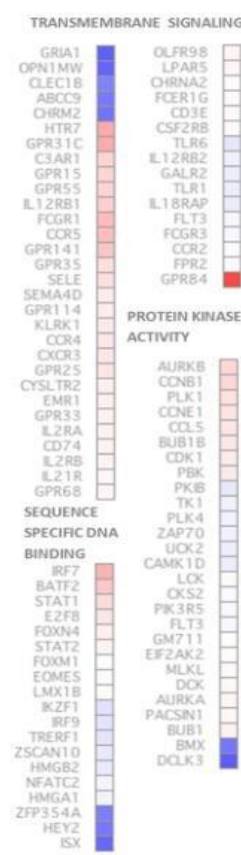

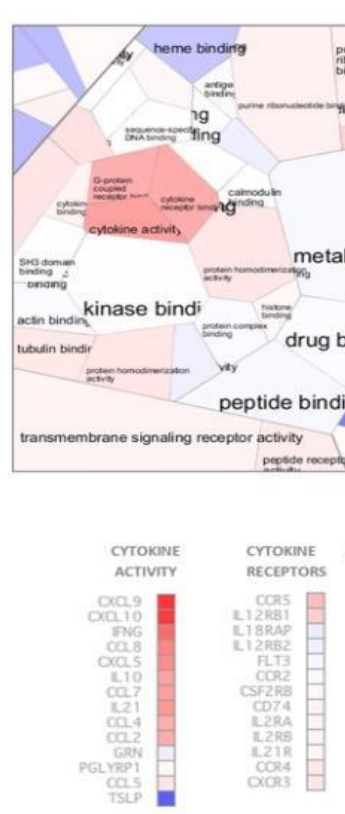

INTERFERON INDUCIBLE GTPASES
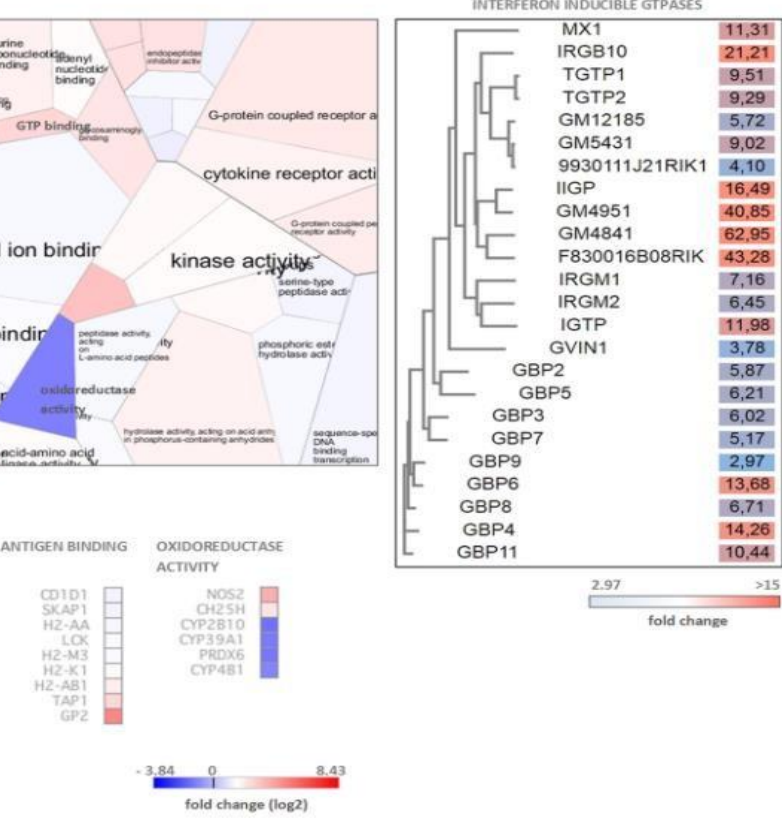

fold change (log2)

FIGURE 3. Functional analysis of the $C$. muridarum infection altered genes by the Voronto method. (A) Analysis of significantly enriched KEGG pathways containing differentially expressed genes. (B) Gene Ontology analysis of significantly enriched molecular function terms containing differentially expressed genes. The differentially expressed IFN-inducible GTPases are grouped based on their amino acid sequences shown separately with their fold of up-regulation. Chlamydia induced inflammation, immunity and antichlamydial defense related Gene Ontology terms and KEGG pathways and the corresponding genes are shown separately. Cell colors of the Voronto diagrams show the mean fold change $\left(\log _{2}\right)$ of the differentially expressed genes related to the particular Voronto cells. Both for the Voronto cells and the genes, the $\log _{2}$ fold changes are color coded according to the scales. Note that the colors of the up-regulated genes ranging from light blue to red, while the down-regulated genes are dark blue. 
were also up-regulated including the MCP1 receptor $C C R 2$, the MCP1-MIP1-RANTES receptor $C C R 4$, the MIP1B receptor CCR5 and the MIG-IP10-I-TAC receptor CXCR3.

Gene Ontology molecular function analysis supported the KEGG pathway analysis (Figure 3B). The fact that various "cell cycle" pathway related genes were found to be up-regulated indicates the accelerated division of activated cells including the induction of BALT. The cellular activation is induced by ligand-receptor interactions in both adaptive and innate immunity. Indeed, among the largest functional groups identified were "cytokine activity", "transmembrane signaling" and "protein kinase activity" containing prominently upregulated and highly upregulated cytokines,

cytokine receptors and downstream signaling genes. Several adaptive immunity related genes, mainly MHC-I antigen presentation related genes were upregulated. The pathogen recognition/ pro-inflammation pathways such as the toll-like receptor (TLR1, TLR6, TLR7, TLR12), cytosolic DNA sensing, NOD-like, RIG-I-like pathways contained up-regulated genes showing that the extra and intracellular forms of the pathogen could be recognized and could induce an inflammatory response. Among the cytokine signaling pathways, IFN-related signaling pathways and IFN-induced gene expressions were particularly noticeable, including up-regulated genes IFNG, STAT1, STAT2, IRF7, IRF9 and IFN-induced genes such as several histocompatibility complex genes, IFN-inducible GTPases and tryptophan catabolism genes IDOI and $K Y N U$.

\subsection{Antimicrobial genes induced by Chlamydia muridarum infection in BALB/c mouse lung tissue}

A prominent identified Gene Ontology molecular functional category was “GTP binding”. Most of the GTPases in this category are involved in defense responses against intracellular pathogens (Figure 3B). Essentially all four classes of murine IFN-inducible GTPases were found to be upregulated including various guanylate-binding proteins (GBP2-9, GBP11), the myxovirus resistance protein-1 (MX1), immunity-related GTPases IRGMI (LRG47), IRGM2 (GTPI), IRGA6 (IIGP), IRGM3 (IGTP), IRGB6 (TGTP1-2), IRGB10 (Gm12250) and a very large IFN-inducible GTPase GVIN1. It is worth to note, that three predicted genes with a sequence homology to IIGP (Gm4841, Gm4951, F830016B08Rik) and three similar to TGTP (Gm12185, Gm5431, 9930111J21Rik1) were found to be up-regulated or highly up-regulated in the infected lungs (Figure 3B). Interestingly, Gm12185, Gm5431 and 9930111J21Rik are localized on chromosome 11, close to the region where potential defense genes against $C$. trachomatis were found by QTL mapping [140] [141]. Besides the IFN-inducible GTPases genes, other genes such as CXCL9, iNOS and IDOI with known anti-chlamydial activity against human and murine Chlamydia 
strains were highly upregulated (127 fold, 14 fold and 24.7 fold, respectively). Additional genes with known antimicrobial activity, but unknown anti-chlamydial activity were found to be upregulated including CXCL11 (345 fold), IRG1 (252.7 fold), lipocalin-2 (11 fold), mucin-5 (8.7 fold) and solute carrier family 11 (5.5 fold).

\section{7. qPCR validation of $I D O 1$ and $I D O 2$ RNA-sequencing data}

A

B
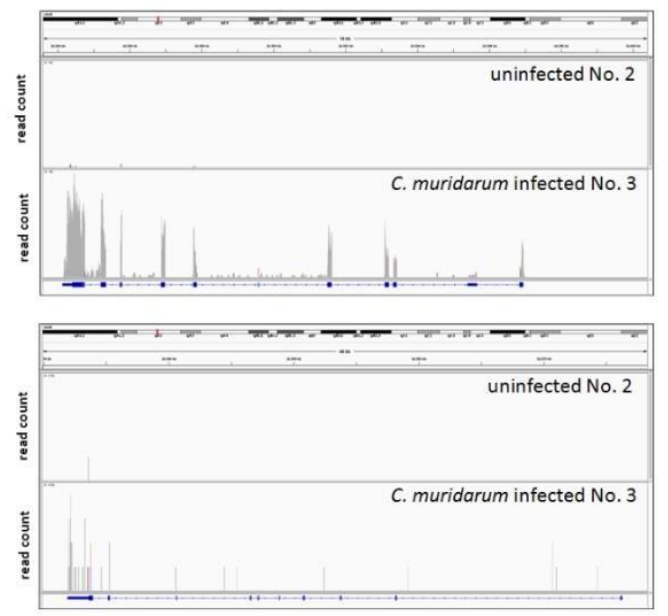

C

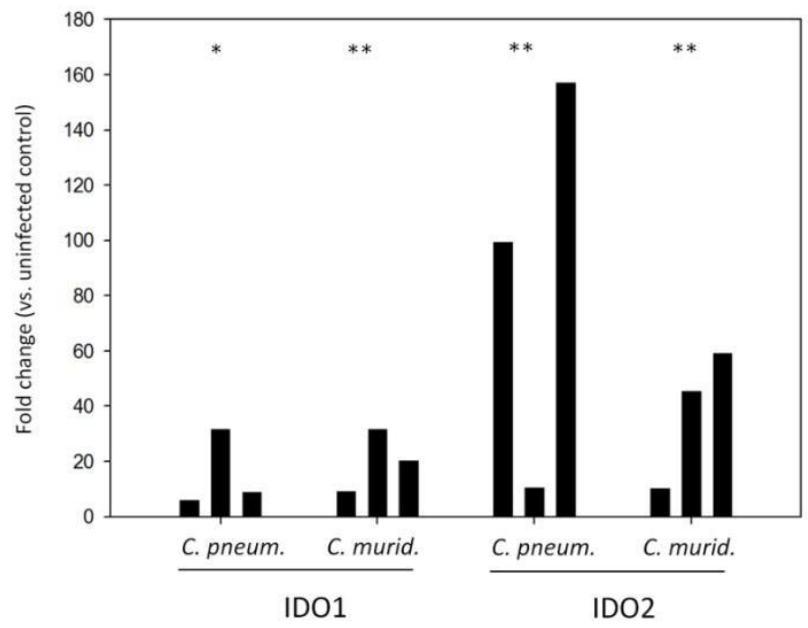

FIGURE 4. IDOI and IDO2 mRNA expression measurements by RNA-Seq and qPCR. Integrative Genomics Viewer [142] images showing the coverage of $I D O I$ (A) and IDO2 (B) genes by sequencing reads in a representative C. muridarum infected and an uninfected control samples. IDOI and IDO2 gene expression inductions measured by qPCR in C. muridarum and C. pneumoniae infected lung tissues (n=3) (C). IDOI and IDO2 gene expression fold changes in each infected mice $(\mathrm{n}=3)$ were calculated by comparing the average $I D O 1$ and $I D O 2$ expressions in the uninfected controls $(\mathrm{n}=3)$. IDOI and $I D O 2$ gene expressions were normalized by the beta-actin gene expressions. $\Delta \mathrm{Ct}$ values $\left(\mathrm{Ct}_{I D O}-\mathrm{Ct}_{a c t i n}\right)$ of the infected and uninfected samples was compared by Student's t-test. **: $P<0.01 *: P$ $<0.05$.

The fact that the IDOI gene was highly upregulated (24.76 fold) in the infected lungs was an unexpected finding since the IDOI was found to be non-inducible by $C$. trachomatis or $C$. muridarum infection in vitro in murine epithelial and other cells [121] [143] [144]. IDO1 was detected as a significantly changed gene $(P=0.037)$ between the $C$. muridarum infected and uninfected samples, while the IDO2 was detected non-significant. However, as Figure 4A-B shows, both IDOI and IDO2 genes had more sequence reads in the infected samples than uninfected ones.

Yet, in the case of $I D O 2$, the read numbers were not high enough to be detected as a significantly changed gene. We used qPCR as an independent method to validate RNA-Seq data for IDOI and IDO2. Also, in order to test whether the IDO1-2 induction is unique to the murine Chlamydia strain, we measured the IDO1-2 gene expressions in C. pneumoniae infected lung samples. qPCR 
data supported the RNA-Seq data in the case of $C$. muridarum infection with a $20.38+/-11.3$ fold and $38.2+/-25.2$ fold of upregulation of IDO1 and IDO2, respectively. qPCR also showed a similar extent of up-regulation 15.5 +/- 14.1 fold and $88.9+/-73.9$ fold for IDOI and IDO2, respectively in the $C$. pneumoniae infected lung tissues (Figure 4C).

\subsection{IDO1-2 protein expression in Chlamydia muridarum and Chlamydia pneumoniae infected BALB/c mouse lung tissues}

To prove that the observed IDOI and IDO2 mRNA changes translated to protein expression changes, and to localize the cell type(s) that express these proteins, we performed an immunohistochemistry of C. muridarum and C. pneumoniae infected lung sections and uninfected controls.
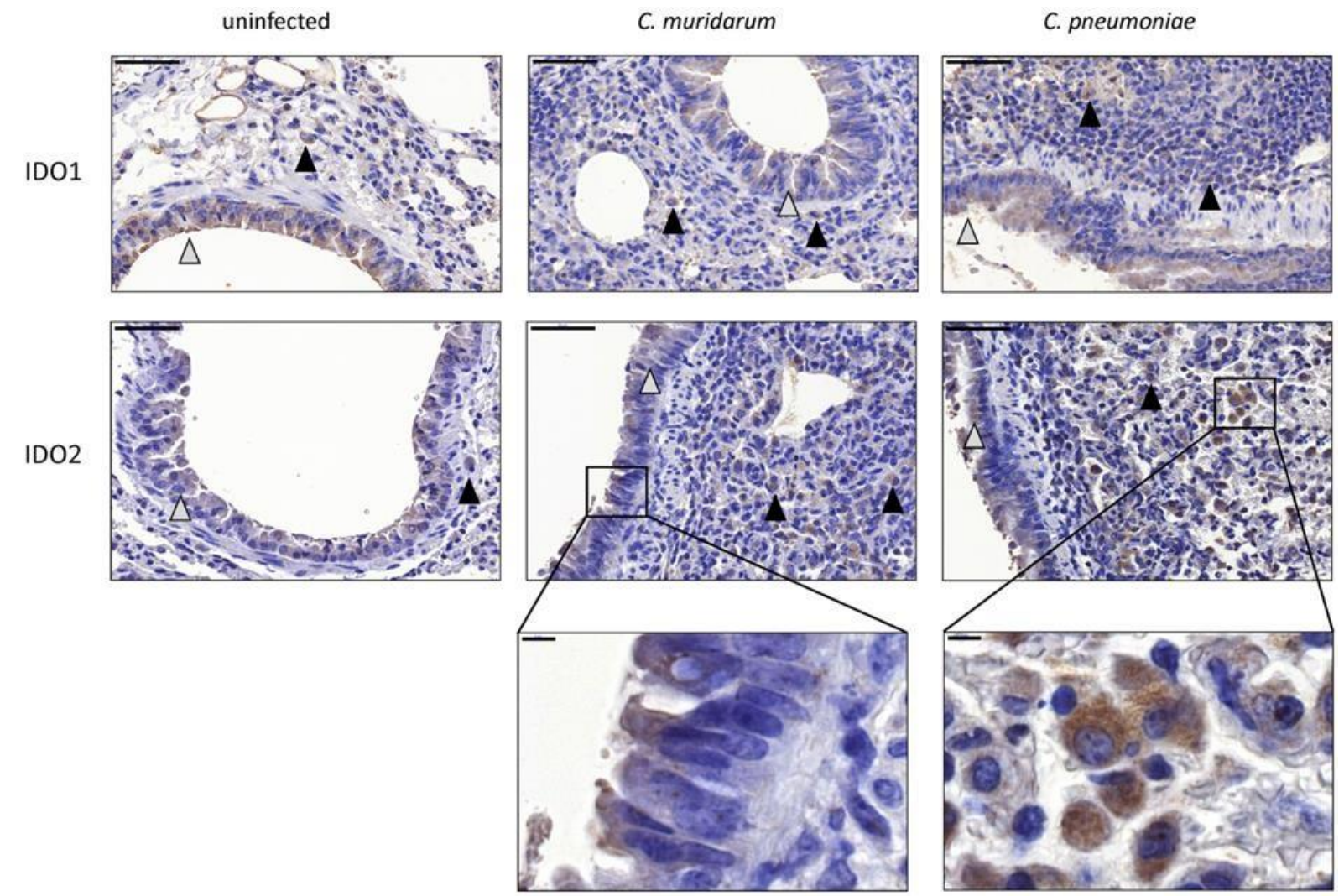

FIGURE 5. Detection of IDO1-2 protein expressions in Chlamydia infected and uninfected BALB/c mouse lungs. IDO1 protein and IDO2 protein expressions detected by immunohistochemistry in $C$. muridarum infected, $C$. pneumoniae infected (7 days post infection) and uninfected control lung tissues. The IDO positive epithelial cells are shown by grey triangles, the IDO positive macrophages are shown by black triangles. Bars: $50 \mu \mathrm{m}$. The characteristic IDO stainings of epithelial cells and macrophages are shown in brackets. Bars: $5 \mu \mathrm{m}$. 
Moderate IDO1-2 positivity could be detected in the cytoplasm of bronchial and occasionally alveolar epithelial cells and moderate/strong positivity was detected frequently in macrophages in the $C$. pneumoniae and C. muridarum infected mouse lung tissues (Figure 5). C. pneumoniae and C. muridarum infections lead to similar IDO1-2 positivity in these cells. The control, uninfected lung tissues were also contained IDO1-2 positive bronchial epithelial cells, and a small number of IDO1-2 positive macrophages.

\subsection{IDO 1-2 activity in Chlamydia muridarum and Chlamydia pneumoniae infected}

\section{BALB/c mouse lung tissues}

To determine whether the expressed IDO1 and IDO2 proteins were functional, we performed a HPLC analysis of the infected and control lung tissues of mice included in the gene expression and immunohistochemistry measurements. We measured IDO1-2 activity by measuring the total tryptophan level, and the level of the tryptophan degradation metabolite kynurenine.

A

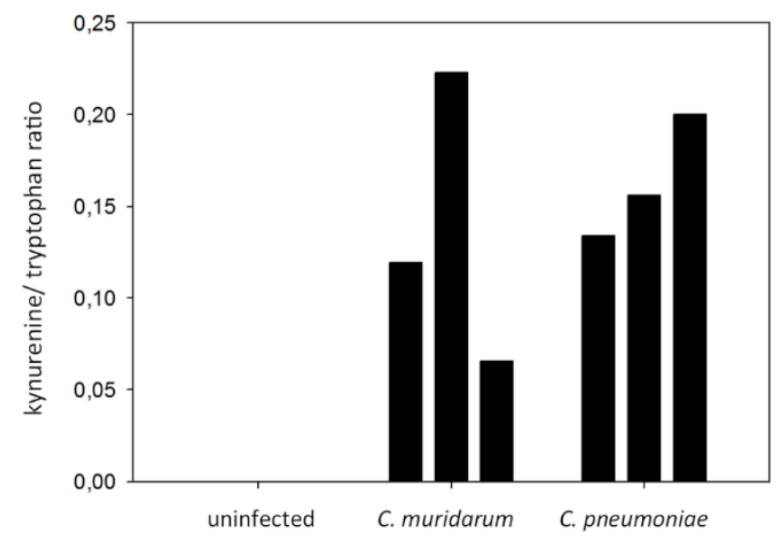

B

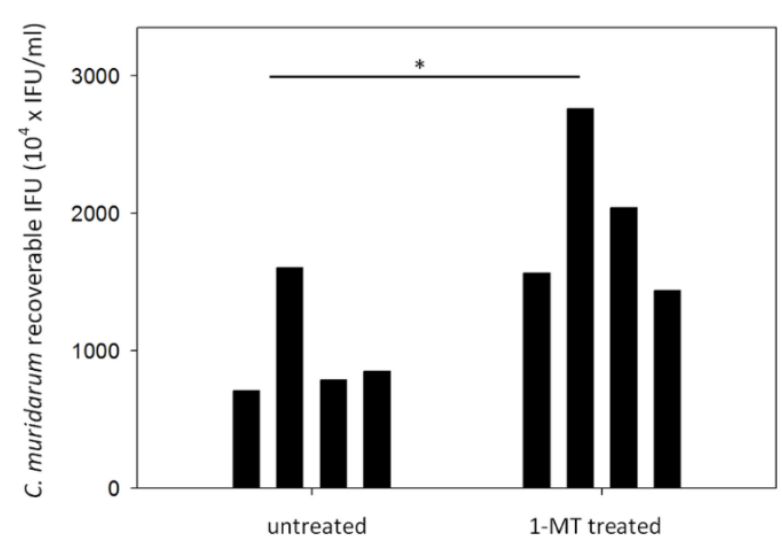

FIGURE 6. Measurement of tryptophan degradation in the Chlamydia infected BALB/c lung tissues and the effect of IDO1-2 inhibition on C. muridarum growth. A, C. muridarum infected, $C$. pneumoniae infected and uninfected lung tissues $(n=3)$ were processed as described in the Materials and Methods for kynurenine and tryptophan concentration measurements at 7 days post infection. Tryptophan degradation was described by measuring the kynurenine/ tryptophan ratio. Kynurenine/ tryptophan ratios of each of the lungs analyzed are shown. Kynurenine concentrations of the uninfected samples were below the limit of detection. $\mathrm{B}$, untreated $(\mathrm{n}=4)$ and 1-MT treated $(\mathrm{n}=4) \mathrm{BALB} / \mathrm{c}$ mice were infected with $C$. muridarum and the recoverable IFUs were measured at 7 days post infection. Recoverable IFUs from each of the analyzed lungs are shown. Recoverable IFUs from untreated and 1-MT treated samples were compared by Student's $t$-test. *: $P<0.05$.

The applied HPLC method could not detect kynurenine in the uninfected lungs, while the $C$. muridarum and C. pneumoniae infected lungs contained 369.6+/- $199.8 \mathrm{nM}$ and 508.7 +/- 176.6 $\mathrm{nM}$. The tryptophan levels were comparable in the infected samples, $2757.2+/-201.5 \mathrm{nM}$ and $3054.1+/-418.1 \mathrm{nM}$ in the $C$. muridarum and C. pneumoniae infected lungs, respectively. The tryptophan levels in the uninfected mice's lungs were slightly lower, $1569.1+/-246.9 \mathrm{nM}$. 
Since we could not control the cell numbers in the infected and control tissues, we normalized the samples by using the kynurenine/tryptophan ratios as described previously [132].

The kynurenine/tryptophan ratios ranged from $0.12-0.22$ in the $C$. muridarum infected samples, 0.13-0.20 in the C. pneumoniae infected samples and it was 0 in the control samples (Figure 6A). To assess the impact of IDO activity on $C$. muridarum growth we inhibited IDO1-2 by 1-MT treatment starting from seven days before infection to seven days post infection. 1-MT treatment lead to a moderate but significant, 1.98 fold increase in $C$. muridarum recoverable IFU at 7 days post infection (Figure 6B).

\subsection{IDO 1-2 mRNA expression and activity in Chlamydia muridarum infected C57BL/6 mouse lung tissues}

To explore whether the Chlamydia-induced IDO1-2 activity could be observed in another mouse strain, we performed qPCR and HPLC analyses of $C$. muridarum infected and control lung tissues of C57BL/6 mice. qPCR data showed a significant increase of IDO1 mRNA level in the $C$. muridarum infected lungs (fold of up-regulation range: 8.14-13.88), and while the IDO2 mRNA up-regulation was not significant, an up-regulation tendency could be observed (fold of upregulation range: 1.71-21.49) (Figure 7A).

A

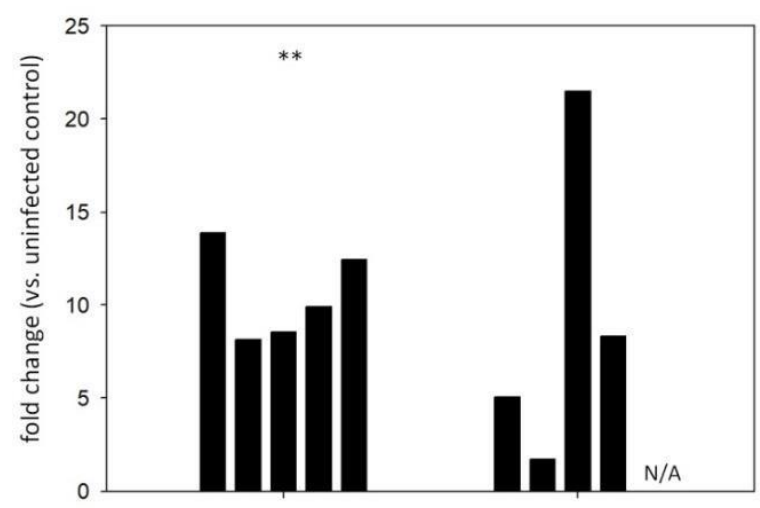

IDO1

IDO2
B

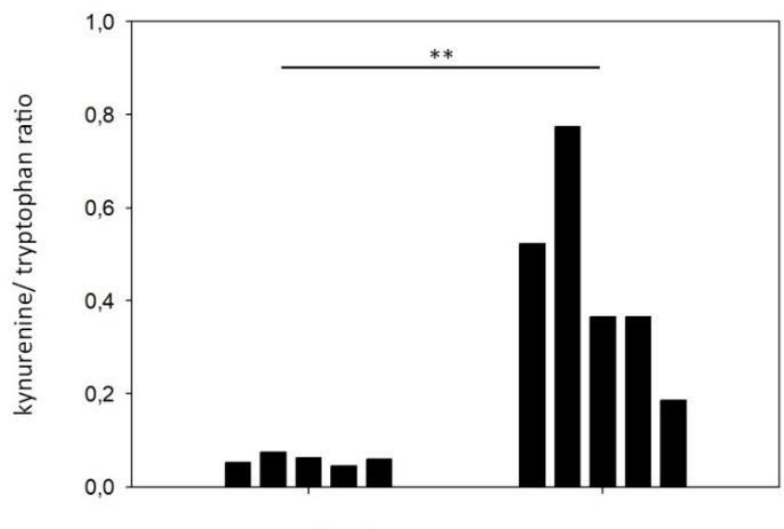

uninfected

FIGURE 7. qPCR measurement of $I D O 1$ and $I D O 2$ gene expressions in the $C$. muridarum infected C57BL/6 lung tissues (A). IDOI and IDO2 gene expression fold changes in each infected mice $(\mathrm{n}=5)$ were calculated by comparing the average IDOI and IDO2 expressions in the uninfected controls $(\mathrm{n}=5)$. IDOI and IDO2 gene expressions were normalized by the beta-actin gene expressions. $\Delta \mathrm{Ct}$ values $\left(\mathrm{Ct}_{I D O}-\mathrm{Ct}_{\text {actin }}\right)$ of the infected and uninfected samples was compared by Student's t-test. **: $P<0.01$. N/A: IDO2 mRNA expression could not be detected. (B) Measurement of tryptophan degradation in the $C$. muridarum infected C57BL/6 lung tissues. $C$. muridarum infected and uninfected lung tissues $(n=5)$ were processed as described previously at 7 days post infection. Kynurenine/ tryptophan concentration ratios of each of the lungs analyzed are shown. Kynurenine/ tryptophan concentration ratios of $C$. muridarum infected and uninfected samples were compared by Student's $t$-test. **: $P<0.01$. 
HPLC analysis of tryptophan and kynurenine contents showed that uninfected C57BL/6 mice lungs contained a small amount of kynurenine (0.045-0.075 kynurenine/ tryptophan concentration ratios), and the $C$. muridarum infection significantly increased the IDO activity (0.185-0.773 kynurenine/ tryptophan concentration ratios) (Figure 7B).

\section{AIM 3: To identify novel antiviral compounds extracted from the berry of sea buckthorn, Elaeagnus rhamnoides and from Rumex aquaticus.}

\subsection{Antiviral activity of compounds 1-3 and 5-8}

We were investigated the antiviral activity of the isolated compounds 1-3 and a structurally close to the naphtoquinone and substituted naphtalenes 5-8 [145]. First, the cytotoxicity of compounds 1-3 and 5-8 was tested at a concentration of $100-0.78 \mu \mathrm{M}$.

A

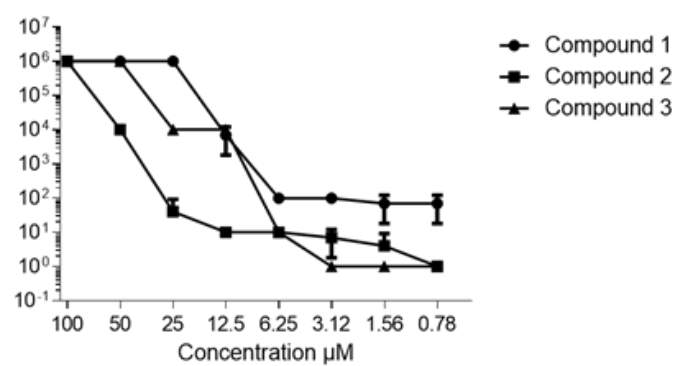

C

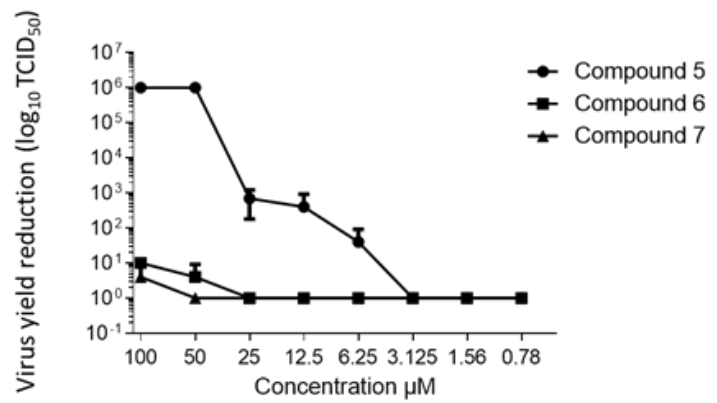

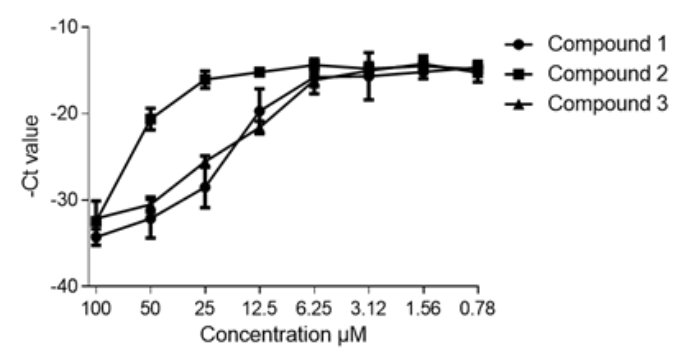

D

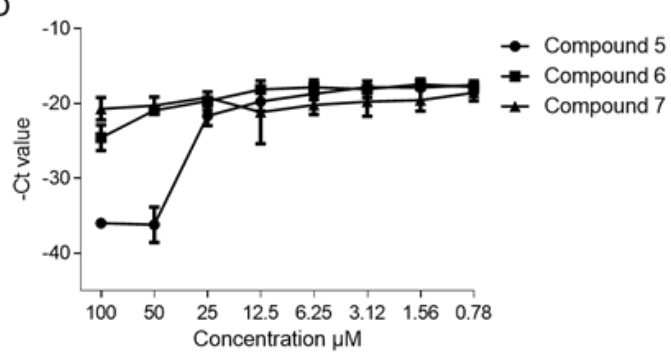

FIGURE 8. Antiviral effect of compounds 1-3 and 5-7. Vero cells were infected with HSV-2 MOI (0.01) in the presence of various concentrations of the test compounds and were incubated for $24 \mathrm{~h}(\mathrm{n}=4)$. At $24 \mathrm{~h}$ post-infection, the cells were lysed and the virus yield reduction induced by the test compounds was evaluated by comparing the yield to that seen in untreated Vero cells. (Data represent the geometric means of virus yield reduction and standard deviations) (Fig. A, C). The HSV-2 DNA concentration in the lysates was measured by direct qPCR (Fig. B, D). (Data represent the average $-\mathrm{Ct}$ values standard deviation) 
All the compounds were dissolved in DMSO and diluted in culture medium. The maximum concentration of DMSO showed no cytotoxicity for Vero cells. After $24 \mathrm{~h}$ of incubation, cell viability was determined by the MTT test. The compounds showed a $\mathrm{CC}_{50}$ value higher than 100 $\mu \mathrm{M}$, except for compound 8, which was rather toxic for Vero cells with a $\mathrm{CC}_{50}$ value of $6.25 \mu \mathrm{M}$ (data not shown).

Applying traditional virus yield reduction assay, compounds 1 and 3 was found to cause a $2 \log _{10}$ and $3.49 \log _{10}$ reduction of HSV-2 yield, respectively, at a concentration of $12.5 \mu \mathrm{M}$, compared to the virus titer of untreated control samples (Figure 8A). This finding is in line with literature data, which demonstrate that acyclovir, the gold standard of anti-HSV therapy, produces a 1-5.06 $\log _{10}$ reduction of HSV-2 yield at a concentration of $6.25 \mu \mathrm{M}$ [134]. Compound 2 exerted antiviral activity at concentrations of $50 \mu \mathrm{M}$ or higher only. Musizin (5) has antiviral activity at a concentration of $12.5 \mu \mathrm{M}$, causing a $2.33 \log _{10}$ reduction in virus yield (Figure $8 \mathrm{C}$ ). The antiHSV-2 effect of musizin (5) demonstrated in our experiments is concordant with the result of Gescher et al. who reported the anti-HSV-1 activity of this compound [146].

To validate our results, the direct qPCR method was used [136] to determine the level of HSV-2 growth inhibition induced by serial dilutions of the compounds in the virus-infected cells. Similarly, to our findings from the yield reduction assay, inhibition curves based on the qPCR results showed that the most potent compounds against HSV-2 were compounds 1 and 3 (Figure 8B). The maximum HSV-2 growth corresponded to a DNA concentration of $\mathrm{Ct} \sim 15$ in the direct qPCR assay. The compound concentration that decreased HSV-2 growth and corresponding DNA content by $50 \%$ ( $\left.\mathrm{IC}_{50}\right)$, increased the $\mathrm{qPCR} \mathrm{Ct}$ value by approximately one cycle. Also, the compound concentration that inhibited HSV-2 growth by $90 \%$ ( $\mathrm{IC}_{90}$ ), raised the $\mathrm{Ct}$ value by $\sim 3.32$ cycles. In case of compounds 1 and 3 the $\mathrm{IC}_{50}$ and $\mathrm{IC}_{90}$ values were between 6.25 and $12.5 \mu \mathrm{M}$, while the $\mathrm{IC}_{50}$ value for compound 2 was $\sim 25 \mu \mathrm{M}$ and the $\mathrm{IC}_{90}$ value for compound 2 was between 25 and $50 \mu \mathrm{M}$ (Fig. 8B). Musizin (5) also exerted a high antiviral activity with an $\mathrm{IC}_{50}$ of $\sim 12.5$ $\mu \mathrm{M}$ and $\mathrm{IC}_{90}$ of 25-50 $\mu \mathrm{M}$ (Figure 8D). Torachrysone-8-O-glucoside (7) had no effect on HSV-2 growth in the concentration range applied, while the $\mathrm{IC}_{50}$ value for musizin-8-O-glucoside (6) was $\sim 25 \mu \mathrm{M}$ and the $\mathrm{IC}_{90}$ value was between 50 and $100 \mu \mathrm{M}$. 2-methoxystipandron (8) did not show any antiviral effect at the non-toxic concentration of $6.25 \mu \mathrm{M}$ (data not shown). 


\section{DISCUSSION}

\section{AIM 1: In vitro and in vivo monitoring of the effect of hydroxyethyl cellulose a major gelling agent of vaginal gels on $C$. trachomatis growth.}

Interestingly, our results are different from those of Sater et al. [147], who used the lymphogranuloma venereum strain $C$. trachomatis $\mathrm{L} 2$ and showed a concentration- and $\mathrm{pH}-$ dependent inhibitory effect of HEC on chlamydial growth in vitro. However, there are important differences between the two studies, including the fact that we used a complex buffer which may mimic better the physicochemical properties of the vaginal fluid than the phosphate and acetate buffers used by Sater et al.. Moreover, we observed the growth enhancing effect at $1.5-0.75 \% \mathrm{w} / \mathrm{v}$ $(15000-7500 \mathrm{~g} / \mathrm{ml}) \mathrm{HEC}$ concentrations, the concentrations that are common in the vaginal gels [70] [148], while Sater et al. used significantly lower HEC concentrations (2-200 g/ml). Instead of serovar L2, we also used the more prevalent urogenital serovars D and E. While C. trachomatis D and L2 have minor genetic differences [149], there are several phenotypic differences between the two serotypes. Previous studies showed that their early interactions with epithelial cells are different [150] [151], including the fact, that the centrifugation and dextrane pretreatment of host epithelial cells increased the infection efficacy of urogenital C. trachomatis serovars but had no impact on serovar L2. In addition, serovar E infection is heparin independent while serovar L2 infection exhibits a strong heparin dependency [152]. Since probably HEC influences the early interactions between the EBs and the host cells, this effect may be different between the LGV and urogenital serovars.

Altogether, our study shows that vaginal gel components, such as the gelling agent HEC have a significant growth enhancing effect on two prevalent $C$. trachomatis urogenital serovars. This enhancing effect was observed in vitro over a wide $\mathrm{pH}$ range, at lower concentrations, and also in vivo. Since the growth enhancement can theoretically lower the minimal number of bacteria required for infection transmission, these results suggest the need for testing current and future vaginal gels to determine their growth enhancing effects on $C$. trachomatis and on other sexually transmitted pathogens. 


\section{AIM 2: Identification of murine defense genes that could be involved in the elimination of the murine Chlamydia strain and murine genes that could be effective against the human Chlamydia strains.}

RNA sequencing analysis of the $C$. muridarum infected lungs revealed that the expression of a wide variety of host genes were altered, and several up-regulated genes could contribute in the Chlamydia-induced inflammation and anti-chlamydial defense of the murine host. Genes related to both the innate and adaptive immunity were found to be induced in the $C$. muridarum infected lung tissue. The major functional groups were related to cytokine/chemokine expression, chemotaxis, signal transduction, antigen presentation, cell division and innate antimicrobial defense. According to the cellular theory of chlamydial pathogenesis, non-immune cells trigger the inflammation by secreting pro-inflammatory cytokines and chemokines [153]. While the cellular source of the cytokines/chemokines cannot be identified by a tissue-level gene expression analysis, in toto the strong gene expression imprint of chemotaxis induction and cellular influx could be identified in the $C$. muridarum infected mouse lungs. The autocrine-paracrine effects of the secreted cytokines and the cell-to-cell interactions between resident and novel cells could result a milieu that induced a complex gene expression including the induction of certain antichlamydial genes.

Several members of the IFN-inducible GTPase family were found to be highly induced. Although we did not measure the gene expression changes induced by the $C$. pneumoniae, previous studies showed that both the murine and human Chlamydia strains were able to induce IFN-inducible GTPases [143] [154]. GTPases IRGMI (LRG47), IRGM3 (IGTP), IRGA6 (IIGP) and IRGB10 were found to be upregulated or highly-upregulated, and have been shown to be involved in the clearance of the human C. trachomatis strain [140] [143] [155], but likely not effective against the murine Chlamydia [69] [81]. Novel GTPase genes were also found to be highly up-regulated after $C$. muridarum infection, and could be involved in the anti-chlamydial defense. Three of these genes $(G m 12185, G m 5431,9930111 J 21 R i k 1)$ show a sequence similarity to IRGB10, a known murine defense gene against [140]. Interestingly, Coers et. al showed that $C$. muridarum was capable of evading the anti-chlamydial effect of IRGB10 [155]. Altogether, the differential sensitivity to the IFN-inducible GTPases could explain the fact that despite using 400 fold more C. pneumoniae IFU than C. muridarum, we recovered comparable IFUs from the infected lungs. The other known anti-chlamydial gene $i N O S$ was also up-regulated (14 fold). iNOS induction has been shown to be an important mechanism in the later phase elimination of $C$. muridarum infection from the mouse genital tract [156] and also in RAW 264.7 murine macrophages [157]. 
$I R G 1$, another IFN-inducible gene [158] [159] was found to be highly up-regulated (252.7 fold) after C. muridarum infection. IRG1 was shown to be expressed in macrophages [160], associated with Legionella pneumophila vacuoles in macrophages and possessed antimicrobial activity by increasing reactive oxygen species production [160] and by the direct bactericidal effect of itaconic acid production [159]. A CXC chemokine, $M I G$ was also highly up-regulated (127 fold) after $C$. muridarum infection. Interestingly, the size, the cationic charge and amphipathic nature of CXC chemokines are similar to certain antimicrobial peptides [161]. We showed previously that MIG had a concentration-dependent direct toxicity to the elementary bodies of $C$. muridarum, C. trachomatis [154] and C. pneumoniae [162].

RNA sequencing and qPCR revealed that the IDOI and IDO2 genes were also highly induced in the infected lungs. To identify the source of IDO activity, we performed IDO1-2 IHC in infected and control lung tissues. We found that lung bronchial epithelial cells had a moderate level of IDO1-2 positivity both in the control and infected tissues, indicating a lower-level, steady-state expression. A higher level of IDO1-2 positivity was detected in leukocytes, prominently in macrophages, in both the uninfected and infected tissues, but the number of positive cells was higher in the Chlamydia-infected tissues. The higher number of IDO1-2 positive macrophages might be a result of in situ IDO1-2 induction and/or the influx of already IDO1-2 positive monocytes into the inflamed tissue. It is also possible that the IDO1-2 positive macrophages were activated locally resulting a higher IDO1-2 activity. Previous in vivo studies showed a tissue level IDO induction in various murine tissues infected by Escherichia coli [163], Plasmodium berghei [164], and Toxoplasma gondii [165]. Interestingly, C. pneumoniae induced lung IDO1 expression was also shown in RAG -/- mice, but not in the wild type C57BL/6 controls [166]. Cellular level IDO induction in vivo was detected in murine intestinal epithelial cells after Eimeria falciformis infection [167], in lung epithelial cells after influenza A virus infection [168] and in lung epithelial cells, endothelial cells and macrophages/dendritic cells after Mycobacterium tuberculosis infection [169]. Knockout studies showed that - similarly to humans - one of the major inducers of IDO expression is IFN- $\gamma$ and IFN- $\alpha / \beta$ in murine tissues in vivo [163] [168]. According our gene expression data one of the prominent networks induced by $C$. muridarum infection was the IFN signaling pathway, therefore the IFN impact of IDOI-2 gene induction was clearly present in the Chlamydia-infected tissues. HPLC detection of the tryptophan degradation product kynurenine demonstrated that $i$, in the uninfected murine lung tissues IDO activity was not detectable, hence the low level IDO1-2 protein positivity detected in uninfected epithelial cells and macrophages did not yield significant tryptophan catabolism ii, IDO1-2 enzymes were induced and functionally active in both the murine and human Chlamydia infected lung tissues. A quantitative IHC was not performed, but the observation of similar level of IDO1-2 IHC positivity 
in epithelial cells before and after infection indicates that the IDO1-2 was not induced and IDO12 activity might not be involved in the elimination of Chlamydia from the murine lung epithelial cells. Further quantitative studies needed to clarify the exact role of murine epithelial IDO expression. The fact that C57BL/6 mouse lungs also showed Chlamydia infection induced IDO activity, supports the possibility that the observed IDO induction is not a mouse strain-specific response.

The role of murine IDO in the clearance of Chlamydia in vivo is not well defined. IDO1 knockout mice cleared $C$. muridarum from the urogenital tract with similar - but not identical - kinetics to the wild types [157], but it should be noted that IDO2 gene was intact in these animals [170] [171]. To clarify the antimicrobial role of IDO1-2 activity we treated BALB/c mice with 1-MT, a previously described inhibitor of IDO1 [172] and IDO2 [173]. IDO inhibition showed that there was a moderate but significant, $\sim 2$ fold increase in $C$. muridarum recoverable IFU in 1-MT treated mice indicating that IDO activity influenced the $C$. muridarum replication in vivo.

Both the $C$. muridarum and $C$. pneumoniae infections clearly lead to the presence of IDO1-2 positive macrophages, and this leukocyte influx/activation was a major factor in the observed increase in IDO1-2 activity. The high upregulation of various monocyte chemokines $M C P 1-2-3$, $M I P 1 B, I P-10$ and monocyte chemokine receptors CCR2-4-5, CXCR3 support the monocyte influx-mediated IDO1-2 expression increase. Monocytes have been implicated in the spread of C. pneumoniae from the primary site of infections [174], but human monocytes were able to suppress C. trachomatis growth via IDO-dependent [175] and IDO-independent mechanisms [176] [177] [178]. Whether the IDO activity of murine macrophages contributes to the control of C. muridarum and C. trachomatis growth, needs further investigation.

There are limitations of our study that need further investigations. We could not detect IDO 1-2 inducibility in epithelial cells, but the applied IHC was not a quantitative method. Since epithelial cells are the sites of chlamydial replication, the isolation of lung epithelial cells and the measurement of their steady state and infection-induced IDO activity are critical points and a goal we are currently pursuing. The other obvious targets to assess IDO activity are the isolated epithelial cells of the uninfected and infected murine urogenital tract. The role of IDO2 is not defined. The lung IDO2 mRNA was clearly induced by Chlamydia infection, but its RNA-seq read numbers were significantly lower than IDO1 reads. In order to assess the potential role of IDO2, the IDO2 protein concentrations in isolated lung epithelial cells and macrophages has to be measured and compared to IDO1. Also, chemical inhibition of IDO showed a significant, albeit limited phenotypic effect. This could be due to the limited defensive role of IDO1-2 or the 
incomplete inhibition of the enzymes. Further studies with optimized IDO inhibition protocol and more time points post infection are needed.

Chlamydia can avoid intracellular defense responses by using metabolic shunt [69], inactivating cellular effector proteins such as IFN-inducible GTPases [143] [155], or avoiding the induction of the intracellular effectors [178]. Our, in vivo study showed that -at the tissue level- various antibacterial mechanisms are switched on and IDO1-2 could be related to this effector repertoire.

\section{AIM 3: To identify novel antiviral compounds extracted from the berry of sea buckthorn, Elaeagnus rhamnoides and from Rumex aquaticus.}

The dose dependent inhibitory effect of certain sesquiterpenes $(1,2)$, phenylpropane dimer (3), naphthalenes (5-7), and 14-naphthoquinone (8) derivatives isolated from E. rhamnoides (1-3) and R. aquaticus (5-8) were investigated against HSV-2 virus infected Vero cells, by applying the traditional virus yield reduction test and the qPCR method. Compounds 1 and 3, as well as musizin (5) were demonstrated to have a potent anti-HSV-2 activity. In case of glucosides, such as musizin-8-O-glucoside (6), only a moderate anti-HSV-2 activity was observed. Isolating two new 14-noreudesmane sesquiterpenes $(1,2)$ from sea buckthorn, and demonstrating the antiviral properties of several compounds present in the fruit peel of the plant are significant novelties of our study. Based on our results, sea buckthorn is worth being further studied, as it could be a potential source of agents with considerable anti-HSV-2 activity, and thus it might provide alternative drug candidates for the treatment of patient populations infected with acyclovir- and penciclovir-resistant strains of the virus. 


\title{
6. THE FOLLOWING ARE CONSIDERED NOVEL
}

\begin{abstract}
AIM 1:
The gelling agent, HEC have a significant growth-enhancing effect on the two prevalent $C$. trachomatis urogenital serovars. This enhancing effect was observed in vitro over a wide $\mathrm{pH}$ range, even at $0,375 \%$ concentrations, and also in vivo. Since the growth enhancement can theoretically lower the minimal number of bacteria required for infection transmission, these results suggest the need for testing current and future vaginal gels to determine their growth enhancing effects on

C. trachomatis and on other sexually transmitted pathogens.
\end{abstract}

\section{AIM 2:}

Infection with two different Chlamydia strains in BALB/c murine lungs, showed highly expressed IDO 1-2 amongst other host defense genes. It is a novel finding, since IDO was considered as a unique human anti-chlamydial defense gene.

IDO 1-2 activity were also increased in C. muridarum infected C57BL/6 lung tissues, indicating that this phenomenon is not mouse strain specific.

\section{AIM 3:}

Out of three extracted compounds from E. rahmnoides two had a potent anti-HSV-2 activity, compound 1 (a sesquiterpen) and compound 3 (a phenylpropane heterodimer). Among the derivatives isolated from $R$. aquaticus compound 5 (musizin) showed a very potent anti-HSV-2 activity while compound 6 (musizin-8-O-glicoside) has a moderate anti-HSV-2 activity. 


\section{SUMMARY}

STDs are a persistent problem globally, worldwide more than 1 million STDs are acquired every day, and these numbers tend to increase. Amongst bacterial STDs C. trachomatis infections are the most prevalent.

The transmission of the urogenital serovars of $C$. trachomatis can be significantly influenced by vaginal gels. HEC is a commonly used gelling agent that can be found in various vaginal gels. We investigated the effect of HEC on the $C$. trachomatis serovar D growth and found that it had a growth-enhancing effect, both in vitro and in vivo. In addition, in vitro investigation of the impact of HEC on C. trachomatis serovar E growth also showed enhancing effect.

The prevention of the Chlamydia infections with vaccination, would be a potent option to decrease the prevalence of chlamydial infections. Mouse models are generally used for vaccine development, to study the immune response and histopathology associated with Chlamydia infection. An important question, regarding murine models is the in vivo identification of murine host genes responsible for the elimination of the murine and human Chlamydia strains. $C$. muridarum infected BALB/c lung transcriptome revealed that several genes with direct antichlamydial functions were induced at the tissue level, various members of the IFN-inducible GTPase family, the CXCL chemokines CXCL9, CXCL11, immunoresponsive gene 1, iNOS and lipocalin-2. IDO1-2, the previously described potent anti-chlamydial host enzymes were also highly expressed in the infected murine lungs. This finding was novel, since IDO was considered as a unique human anti-chlamydial defense gene. Besides a lower level of epithelial cell positivity, immunohistochemistry showed that IDO1-2 proteins were expressed prominently in macrophages. Detection of the tryptophan degradation product kynurenine and the impact of IDO inhibition on $C$. muridarum growth proved that the IDO1-2 proteins were functionally active. IDO1-2 activity also increased in C. muridarum infected C57BL/6 lung tissues, indicating that this phenomenon was not mouse strain specific.

Another prevalent, sexually transmitted intracellular pathogen is HSV-2. Various therapeutic agents can be used for the treatment of HSV-2 infections, however, infections by drug resistant HSV represent a persisting treatment concern, especially in the immune-compromised population. To identify a possibly novel antiviral compound extracted from the berry of sea buckthorn, we investigated the in vitro antiviral effects of these compounds against HSV-2. Applying the traditional virus yield reduction test and qPCR methods, we found, that two extracted compounds from E. rahmnoides have a potent anti-HSV-2 activity, compound 1 (sesquiterpen) and 3 (phenylpropane heterodimer). Derivatives isolated from $R$. aquaticus compound 5 (musizin) 
showed a very potent anti-HSV-2 activity as well, while compound 6 (musizin-8-O-glicoside) had a moderate anti-HSV-2 activity.

\section{8. ÖSSZEGZÉS}

A szexuális úton terjedő betegségek folyamatos problémát jelentenek világszerte. Naponta több mint egymillió ember fertőződik meg valamilyen szexuális úton terjedő kórokozóval, és ezeknek a megbetegedéseknek az incidenciája többségében növekvő tendenciát mutat. A szexuális úton terjedő kórokozók közül a C. trachomatis az egyik leggyakoribb.

A C. trachomatis urogenitális szerovariánsainak fertőzőképességét jelentősen befolyásolhatják a vaginális gélek. A HEC az egyik leggyakrabban használt gélképző ágens a vaginális gélekben. In vivo és in vitro környezetben is megvizsgáltuk a HEC C. trachomatis D szerovariánsára gyakorolt hatását. Szignifikáns növekedést serkentő hatást tapasztaltunk, mind az in vitro és in vivo kísérleteink esetében. Ezt megerösítve, a $C$. trachomatis E szerovariánsát is megvizsgáltuk in vitro kísérletben és ezen szerovariáns esetében is szignifikáns növekedést serkentő hatást tapasztaltunk.

A Chlamydia fertőzések védőoltásokkal történő megelőzése hatékonyan csökkenthetné a a fertőzések előfordulását. A Chlamydia-ellenes védőoltások kifejlesztésénél többnyire egérmodelleket használnak a fertőzéssel kapcsolatos immunválasz és a hisztopathológia tanulmányozása céljából. Ezért fontos kérdés, mind az egér és emberi Chlamydia szerotipusok esetében, az eliminálásukban szerepet játszó egér gének in vivo azonosítása. A C. muridarum által megfertőzött BALB/c tüdő transzkriptom analízise azt mutatta, hogy számos közvetlen Chlamydia-ellenes gén szövetszinten nagymértékben kifejeződik, mint például az interferonindukált GTPáz család, a CXCL kemokinek közül a CXCL9 és CXCL11, az immunoreszponzív gén-1, iNOS2 és lipocalin-2. Az IDO1-2, melyeket korábban hatékony Chlamydia-ellenes gazdasejti enzimekként írtak le, szintén nagymértékben kifejeződtek a fertőzött egértüdőkben. Ez egy új megfigyelés, mivel az IDO korábban kizárólag humán Chlamydia-ellenes génnek számított. Az alacsonyabb hámsejti pozitivitás mellett az immunohisztokémia azt mutatta, hogy az IDO1-2 fehérjék nagymértékben jelentek meg a makrofágokban. Az IDO működésének jele a triptofán bomlástermék kinurenin megjelenése. A kinurenin szint növekedése azt igazolta, hogy az IDO1-2 proteinek nemcsak fokozott mértékben termelődtek, hanem funkcionálisan aktívak is voltak. Az IDO1-2 génexpresszió és aktivitás szintén megnövekedett a $C$. muridarum által fertőzött C56BL/6 tüdőszövetekben, mely arra utal, hogy ez a jelenség nem egértörzsre 
specifikus. Végezetül, az IDO gátlás hatására a $C$. muridarum szaporodása szignifikánsan megnövekedett BALB/c egértüdőben azt bizonyítva, hogy aktív szerepük lehet a Chlamydia fertőzés eliminálásában.

A HSV-2 egy másik jelentős, szexuális úton terjedő kórokozó. Több terápiás szer is használatban van a HSV-2 fertőzések kezelésére, de a gyógyszer-rezisztens mutánsok megjelenése miatt további fejlesztések szükségesek. Potenciálisan új antivirális vegyületek azonosítása céljából megvizsgáltuk a homoktövis terméséből kivont vegyületek in vitro antivirális hatását a HSV-2 ellen. A tradicionális vírushozam reduckiós teszt és qPCR módszerek alkalmazásával azt az eredményt kaptuk, hogy E. rahmniodes-ból kivont két vegyület is hatékony HSV-2-ellenes aktivitással bír: az 1. számú vegyület (sesquiterpén) és a 3. számú vegyület (fenilpropán heterodimer). Az R. aquaticus-ból kivont 5. számú vegyület (musizin) nagyon hatékony HSV- 2ellenes aktivitással bírt, míg a 8. számú vegyület (musizin-8-O-glicoside) közepes HSV-2- ellenes aktivitással rendelkezett. 


\section{ACKNOWLEDGEMENTS}

Firstly, I would like to express my sincere gratitude to my advisor Dr. Dezsö Virok for the continuous support of my Ph.D study and related researches, for his patience, motivation, and immense knowledge.

My sincere thanks also goes to Dr. Katalin Burián, Head of the Department of Microbiology and Immunobiology, who provided me an opportunity to work at the department, and who gave access to the laboratory and research facilities.

Besides my advisor, I would like to thank to Dr. Valéria Emdrész for the help, advices and her insightful comments and encouragement, which incented me to widen my research from various perspectives.

I am also thankful to Professor Dr. László Vécsei, Dr. Gábor Veres, Dr. Szilárd Poliska, Dr. László Tiszlavicz, Dr. Ferenc Somogyvári and Dr. Gabriella Spengler for the support I received from the collaborative work.

This Ph.D project would not have been possible to complete without the assistance and work of Györgyi Deák, Kitti Ürmös, Anikó Váradi and Szilvia Urbán.

I thank my fellow labmates, especially to Dr. Ildikó Lantos, Dr. Dávid Kókai and Dr. Anita Varga-Bogdanov, for the stimulating discussions and for all the fun we have had in the last three years.

I would like to thank Dávid Vatai for his help in translating and proofreading my thesis and related documents.

I would like to thank my family: my parents and sister for supporting me spiritually throughout writing this thesis and my life in general. I would also like to thank all of my friends who supported me in writing, and incented me to strive towards my goal. Words cannot express how grateful I am.

Last but not the least, I dedicate this thesis to Kamilla Gömöri and Vanessa Müller who had always helped and supported me, without their precious support it would not be possible to conduct this study. 


\section{REFERENCES}

1. Sexually transmitted infections (STIs), https://www.who.int/news-room/factsheets/detail/sexually-transmitted-infections-(stis)

2. Sexually Transmitted Diseases | Healthy People 2020, https://www.healthypeople.gov/2020/topics-objectives/topic/sexually-transmitteddiseases

3. 2016 Sexually Transmitted Diseases Surveillance, https://www.cdc.gov/std/stats16/default.htm

4. Lymphogranuloma venereum - Annual Epidemiological Report 2016 [2014 data], http://ecdc.europa.eu/en/publications-data/lymphogranuloma-venereum-annualepidemiological-report-2016-2014-data

5. Baams, L., Overbeek, G., Dubas, J.S., van Aken, M.A.G.: On Early Starters and Late Bloomers: The Development of Sexual Behavior in Adolescence Across Personality Types. J. Sex Res. 51, 754-764 (2014). doi:10.1080/00224499.2013.802758

6. Ibitoye, M., Choi, C., Tai, H., Lee, G., Sommer, M.: Early menarche: A systematic review of its effect on sexual and reproductive health in low- and middle-income countries. PLoS ONE. 12, (2017). doi:10.1371/journal.pone.0178884

7. Chlamydiales - an overview | ScienceDirect Topics, https://www.sciencedirect.com/topics/medicine-and-dentistry/chlamydiales

8. Mühldorfer, I., Schäfer, K.P.: Emerging Bacterial Pathogens. Karger Medical and Scientific Publishers (2001)

9. Morrison, R.P., Caldwell, H.D.: Immunity to Murine Chlamydial Genital Infection. Infect. Immun. 70, 2741-2751 (2002). doi:10.1128/IAI.70.6.2741-2751.2002

10. Miyairi, I., Mahdi, O.S., Ouellette, S.P., Belland, R.J., Byrne, G.I.: Different Growth Rates of Chlamydia trachomatis Biovars Reflect Pathotype. J. Infect. Dis. 194, 350-357 (2006). doi:10.1086/505432

11. Dunlop, E.M., Darougar, S., Treharne, J.D.: Epidemiology of infection by serotypes D to K of chlamydia trachomatis. Br. J. Vener. Dis. 56, 163-168 (1980). doi:10.1136/sti.56.3.163

12. Spaargaren, J., Fennema, H.S.A., Morré, S.A., de Vries, H.J.C., Coutinho, R.A.: New Lymphogranuloma Venereum Chlamydia trachomatis Variant, Amsterdam. Emerg. Infect. Dis. 11, 1090-1092 (2005). doi:10.3201/eid1107.040883

13. Lymphogranuloma Venereum (LGV): Background, Pathophysiology, Epidemiology. (2019)

14. El Yazouli, L., Criscuolo, A., Hejaji, H., Bouazza, M., Elmdaghri, N., Aroussi Alami, A., Amraoui, A., Dakka, N., Radouani, F.: Molecular characterisation of Chlamydia pneumoniae associated to atherosclerosis. Pathog. Dis. 75, (2017). doi:10.1093/femspd/ftx039

15. Everett, K.D., Bush, R.M., Andersen, A.A.: Emended description of the order Chlamydiales, proposal of Parachlamydiaceae fam. nov. and Simkaniaceae fam. nov., each containing one monotypic genus, revised taxonomy of the family Chlamydiaceae, including a new genus and five new species, and standards for the identification of organisms. Int. J. Syst. Bacteriol. 49 Pt 2, 415-440 (1999). doi:10.1099/00207713-49-2415

16. Moorman, D.R., Sixbey, J.W., Wyrick, P.B.: Interaction of Chlamydia trachomatis with human genital epithelium in culture. J. Gen. Microbiol. 132, 1055-1067 (1986). doi:10.1099/00221287-132-4-1055

17. Elwell, C., Mirrashidi, K., Engel, J.: Chlamydia cell biology and pathogenesis. Nat. Rev. Microbiol. 14, 385-400 (2016). doi:10.1038/nrmicro.2016.30

18. Community, N.R.M.: Size matters for Chlamydia, https://naturemicrobiologycommunity.nature.com/users/71727-christinesutterlin/posts/28982-size-matters-for-chlamydia 
19. Bastidas, R.J., Elwell, C.A., Engel, J.N., Valdivia, R.H.: Chlamydial Intracellular Survival Strategies. Cold Spring Harb. Perspect. Med. 3, (2013).

doi:10.1101/cshperspect.a010256

20. Elwell, C., Mirrashidi, K., Engel, J.: Chlamydia cell biology and pathogenesis. Nat. Rev. Microbiol. 14, 385-400 (2016). doi:10.1038/nrmicro.2016.30

21. Kägebein, D., Gutjahr, M., Große, C., Vogel, A.B., Rödel, J., Knittler, M.R.: Chlamydia trachomatis-Infected Epithelial Cells and Fibroblasts Retain the Ability To Express

Surface-Presented Major Histocompatibility Complex Class I Molecules. Infect. Immun. 82, 993-1006 (2014). doi:10.1128/IAI.01473-13

22. Moore, E.R., Fischer, E.R., Mead, D.J., Hackstadt, T.: The Chlamydial Inclusion Preferentially Intercepts Basolaterally Directed Sphingomyelin-Containing Exocytic Vacuoles. Traffic Cph. Den. 9, 2130-2140 (2008). doi:10.1111/j.16000854.2008.00828.x

23. Kawai, T., Akira, S.: The roles of TLRs, RLRs and NLRs in pathogen recognition. Int. Immunol. 21, 317-337 (2009). doi:10.1093/intimm/dxp017

24. Redgrove, K.A., McLaughlin, E.A.: The Role of the Immune Response in Chlamydia trachomatis Infection of the Male Genital Tract: A Double-Edged Sword. Front.

Immunol. 5, 534 (2014). doi:10.3389/fimmu.2014.00534

25. Oliveira, J., Reygaert, W.C.: Gram Negative Bacteria. In: StatPearls. StatPearls Publishing, Treasure Island (FL) (2019)

26. Mavoungou, E., Poaty-Mavoungou, V., Touré, F.S., Sall, A., Delicat, A., Yaba, P., Mandeme, Y., Nabias, R., Lansoud-Soukate, J.: Impairment of natural killer cell activity in Chlamydia trachomatis infected individuals. Trop. Med. Int. Health TM IH. 4, 719727 (1999)

27. Romagnani, S.: T-cell subsets (Th1 versus Th2). Ann. Allergy Asthma Immunol. Off. Publ. Am. Coll. Allergy Asthma Immunol. 85, 9-18; quiz 18, 21 (2000). doi:10.1016/S1081-1206(10)62426-X

28. $\mathrm{Su}, \mathrm{H}$., Caldwell, H.D.: CD4+ T cells play a significant role in adoptive immunity to Chlamydia trachomatis infection of the mouse genital tract. Infect. Immun. 63, 33023308 (1995)

29. Bakshi, R.K., Gupta, K., Jordan, S.J., Chi, X., Lensing, S.Y., Press, C.G., Geisler, W.M.: An Adaptive Chlamydia trachomatis-Specific IFN- $\gamma$-Producing CD4+ T Cell Response Is Associated With Protection Against Chlamydia Reinfection in Women. Front. Immunol. 9, (2018). doi:10.3389/fimmu.2018.01981

30. Johnson, R.M., Yu, H., Strank, N.O., Karunakaran, K., Zhu, Y., Brunham, R.C.: B Cell Presentation of Chlamydia Antigen Selects Out Protective CD4 $\gamma 13$ T Cells: Implications for Genital Tract Tissue-Resident Memory Lymphocyte Clusters. Infect. Immun. 86, e00614-17 (2018). doi:10.1128/IAI.00614-17

31. Cui, Z.D., Tristram, D., LaScolea, L.J., Kwiatkowski, T., Kopti, S., Ogra, P.L.: Induction of antibody response to Chlamydia trachomatis in the genital tract by oral immunization. Infect. Immun. 59, 1465-1469 (1991)

32. Sarov, I., Kleinman, D., Cevenini, R., Holcberg, G., Potashnik, G., Sarov, B., Kimmel, N., Insler, V.: Specific IgG and IgA antibodies to Chlamydia trachomatis in infertile women. In: Harrison, R.F., Bonnar, J., and Thompson, W. (eds.) Diagnosis and Management of Tubo-Uterine Factors in Infertility. pp. 63-67. Springer Netherlands, Dordrecht (1984)

33. TERHO, P., MEURMAN, O.: Chlamydial serum IgG, IgA and local IgA antibodies in patients with genital-tract infections measured by solid-phase radioimmunoassay. J. Med. Microbiol. 14, 77-87 (1981). doi:10.1099/00222615-14-1-77

34. Zhang, Y.X., Stewart, S., Joseph, T., Taylor, H.R., Caldwell, H.D.: Protective monoclonal antibodies recognize epitopes located on the major outer membrane protein of Chlamydia trachomatis. J. Immunol. 138, 575-581 (1987) 
35. Sziller, I., Fedorcsák, P., Csapó, Z., Szirmai, K., Linhares, I.M., Papp, Z., Witkin, S.S.: ORIGINAL ARTICLE: Circulating Antibodies to a Conserved Epitope of the Chlamydia Trachomatis 60-kDa Heat Shock Protein is Associated with Decreased Spontaneous Fertility Rate in Ectopic Pregnant Women Treated by Salpingectomy. Am. J. Reprod. Immunol. 59, 99-104 (2008). doi:10.1111/j.1600-0897.2007.00553.x

36. Caldwell, H.D., Perry, L.J.: Neutralization of Chlamydia trachomatis infectivity with antibodies to the major outer membrane protein. Infect. Immun. 38, 745-754 (1982)

37. Fairley, S.J., Singh, S.R., Yilma, A.N., Waffo, A.B., Subbarayan, P., Dixit, S., Taha, M.A., Cambridge, C.D., Dennis, V.A.: Chlamydia trachomatis recombinant MOMP encapsulated in PLGA nanoparticles triggers primarily T helper 1 cellular and antibody immune responses in mice: a desirable candidate nanovaccine. Int. J. Nanomedicine. 8, 2085-2099 (2013). doi:10.2147/IJN.S44155

38. Toye, B., Laferrière, C., Claman, P., Jessamine, P., Peeling, R.: Association between Antibody to the Chlamydial Heat-Shock Protein and Tubal Infertility. J. Infect. Dis. 168, 1236-1240 (1993). doi:10.1093/infdis/168.5.1236

39. Karinen, L., Pouta, A., Hartikainen, A.-L., Bloigu, A., Paldanius, M., Leinonen, M., Saikku, P., Järvelin, M.-R.: Antibodies to Chlamydia trachomatis heat shock proteins Hsp60 and Hsp10 and subfertility in general population at age 31. Am. J. Reprod. Immunol. 52, 291-297 (2004). doi:10.1111/j.1600-0897.2004.00223.x

40. Johnson, R.M.: Murine Oviduct Epithelial Cell Cytokine Responses to Chlamydia muridarum Infection Include Interleukin-12-p70 Secretion. Infect. Immun. 72, 39513960 (2004). doi:10.1128/IAI.72.7.3951-3960.2004

41. Qiao, S., Zhang, H., Zha, X., Niu, W., Liang, J., Pang, G., Tang, Y., Liu, T., Zhao, H., Wang, Y., Bai, H.: Endogenous IL-17A mediated neutrophil infiltration by promoting chemokines expression during chlamydial lung infection. Microb. Pathog. 129, 106-111 (2019). doi:10.1016/j.micpath.2019.01.039

42. Matsuo, J., Sakai, K., Okubo, T., Yamaguchi, H.: Chlamydia pneumoniae enhances Interleukin 8 (IL-8) production with reduced azithromycin sensitivity under hypoxia. APMIS Acta Pathol. Microbiol. Immunol. Scand. 127, 131-138 (2019). doi:10.1111/apm.12924

43. Hou, S., Yue, L., Xu, R., Zhu, C., Shan, S., Wang, H., Liu, Q.: Chlamydia muridarum plasmid induces mouse oviduct pathology by promoting chlamydial survival and ascending infection and triggering host inflammation. Eur. J. Dermatol. EJD. 28, 628-636 (2018). doi:10.1684/ejd.2018.3399

44. Gerard, H.C., Wang, Z., Whittum-Hudson, J.A., El-Gabalawy, H., Goldbach-Mansky, R., Bardin, T., Schumacher, H.R., Hudson, A.P.: Cytokine and chemokine mRNA produced in synovial tissue chronically infected with Chlamydia trachomatis and C. pneumoniae. J. Rheumatol. 29, 1827-1835 (2002)

45. Hakimi, H., Zare-Bidaki, M., Zainodini, N., Assar, S., Arababadi, M.K.: Significant roles played by IL-10 in Chlamydia infections. Inflammation. 37, 818-823 (2014). doi:10.1007/s10753-013-9801-1

46. Wang, C., Tang, J., Crowley-Nowick, P.A., Wilson, C.M., Kaslow, R.A., Geisler, W.M.: Interleukin (IL)-2 and IL-12 responses to Chlamydia trachomatis infection in adolescents. Clin. Exp. Immunol. 142, 548-554 (2005). doi:10.1111/j.1365-2249.2005.02946.x

47. Hocke, A.C., Lampe, M.P., Witzenrath, M., Mollenkopf, H., Zerrahn, J., Schmeck, B., Kessler, U., Krüll, M., Hammerschmidt, S., Hippenstiel, S., Schütte, H., Suttorp, N., Rosseau, S.: Cell-specific interleukin-15 and interleukin-15 receptor subunit expression and regulation in pneumococcal pneumonia--comparison to chlamydial lung infection. Cytokine. 38, 61-73 (2007). doi:10.1016/j.cyto.2007.05.009

48. Tseng, C.-T.K., Rank, R.G.: Role of NK Cells in Early Host Response to Chlamydial Genital Infection. Infect. Immun. 66, 5867-5875 (1998) 
49. Zhong, G., Fan, T., Liu, L.: Chlamydia Inhibits Interferon $\gamma$-inducible Major Histocompatibility Complex Class II Expression by Degradation of Upstream Stimulatory Factor 1. J. Exp. Med. 189, 1931 (1999)

50. Paguirigan, A.M., Byrne, G.I., Becht, S., Carlin, J.M.: Cytokine-mediated indoleamine 2,3-dioxygenase induction in response to Chlamydia infection in human macrophage cultures. Infect. Immun. 62, 1131-1136 (1994)

51. Murray, H.W., Szuro-Sudol, A., Wellner, D., Oca, M.J., Granger, A.M., Libby, D.M., Rothermel, C.D., Rubin, B.Y.: Role of tryptophan degradation in respiratory burstindependent antimicrobial activity of gamma interferon-stimulated human macrophages. Infect. Immun. 57, 845-849 (1989)

52. Wang, Q., Liu, D., Song, P., Zou, M.-H.: Deregulated tryptophan-kynurenine pathway is linked to inflammation, oxidative stress, and immune activation pathway in cardiovascular diseases. Front. Biosci. Landmark Ed. 20, 1116-1143 (2015)

53. Byrne, G.I., Lehmann, L.K., Landry, G.J.: Induction of tryptophan catabolism is the mechanism for gamma-interferon-mediated inhibition of intracellular Chlamydia psittaci replication in T24 cells. Infect. Immun. 53, 347-351 (1986)

54. Ramsey, K.H., Sigar, I.M., Rana, S.V., Gupta, J., Holland, S.M., Byrne, G.I.: Role for Inducible Nitric Oxide Synthase in Protection from Chronic Chlamydia trachomatis Urogenital Disease in Mice and Its Regulation by Oxygen Free Radicals. Infect. Immun. 69, 7374-7379 (2001). doi:10.1128/IAI.69.12.7374-7379.2001

55. Rottenberg, M.E., Gigliotti-Rothfuchs, A., Wigzell, H.: The role of IFN-gamma in the outcome of chlamydial infection. Curr. Opin. Immunol. 14, 444-451 (2002)

56. Stephens, R.S.: The cellular paradigm of chlamydial pathogenesis. Trends Microbiol. 11, 44-51 (2003). doi:10.1016/S0966-842X(02)00011-2

57. Batteiger, B.E., Tu, W., Ofner, S., Van Der Pol, B., Stothard, D.R., Orr, D.P., Katz, B.P., Fortenberry, J.D.: Repeated Chlamydia trachomatis genital infections in adolescent women. J. Infect. Dis. 201, 42-51 (2010). doi:10.1086/648734

58. Lallemand, A., Bremer, V., Jansen, K., Nielsen, S., Münstermann, D., Lucht, A., Tiemann, C.: Prevalence of Chlamydia trachomatis infection in women, heterosexual men and MSM visiting HIV counselling institutions in North Rhine-Westphalia, Germany should Chlamydia testing be scaled up? BMC Infect. Dis. 16, 610 (2016). doi:10.1186/s12879-016-1915-2

59. Bébéar, C., de Barbeyrac, B.: Genital Chlamydia trachomatis infections. Clin. Microbiol. Infect. Off. Publ. Eur. Soc. Clin. Microbiol. Infect. Dis. 15, 4-10 (2009). doi:10.1111/j.1469-0691.2008.02647.x

60. Darville, T., Hiltke, T.J.: Pathogenesis of Genital Tract Disease Due to Chlamydia trachomatis. J. Infect. Dis. 201, S114-S125 (2010). doi:10.1086/652397

61. Cohen, C.R., Brunham, R.C.: Pathogenesis of Chlamydia induced pelvic inflammatory disease. Sex. Transm. Infect. 75, 21-24 (1999)

62. Ceovic, R., Gulin, S.J.: Lymphogranuloma venereum: diagnostic and treatment challenges. Infect. Drug Resist. 8, 39-47 (2015). doi:10.2147/IDR.S57540

63. Rawla, P., Limaiem, F.: Lymphogranuloma Venereum. In: StatPearls. StatPearls Publishing, Treasure Island (FL) (2019)

64. The clinical manifestations of anorectal infection with lymphogranuloma venereum (LGV) versus non-LGV strains of Chlamydia trachomatis: a case-control study in homosexual men. Int. J. STD AIDS. 18, 472-475 (2007). doi:10.1258/095646207781147319

65. Genital elephantiasis and sexually transmitted infections - revisited. Int. J. STD AIDS. 17, 157-166 (2006). doi:10.1258/095646206775809150

66. Geisler, W.M.: Duration of untreated, uncomplicated Chlamydia trachomatis genital infection and factors associated with chlamydia resolution: a review of human studies. J. Infect. Dis. 201 Suppl 2, S104-113 (2010). doi:10.1086/652402 
67. Hammerschlag, M.R.: Chlamydia trachomatis and Chlamydia pneumoniae infections in children and adolescents. Pediatr. Rev. 25, 43-51 (2004)

68. Lyytikäinen, E., Kaasila, M., Hiltunen-Back, E., Lehtinen, M., Tasanen, K., Surcel, H.M., Koskela, P., Paavonen, J.: A discrepancy of Chlamydia trachomatis incidence and prevalence trends in Finland 1983-2003. BMC Infect. Dis. 8, 169 (2008). doi:10.1186/1471-2334-8-169

69. Aiyar, A., Quayle, A.J., Buckner, L.R., Sherchand, S.P., Chang, T.L., Zea, A.H., Martin, D.H., Belland, R.J.: Influence of the tryptophan-indole-IFN $\gamma$ axis on human genital Chlamydia trachomatis infection: role of vaginal co-infections. Front. Cell. Infect. Microbiol. 4, 72 (2014). doi:10.3389/fcimb.2014.00072

70. Mahalingam, A., Simmons, A.P., Ugaonkar, S.R., Watson, K.M., Dezzutti, C.S., Rohan, L.C., Buckheit, R.W., Kiser, P.F.: Vaginal microbicide gel for delivery of IQP-0528, a pyrimidinedione analog with a dual mechanism of action against HIV-1. Antimicrob. Agents Chemother. 55, 1650-1660 (2011). doi:10.1128/AAC.01368-10

71. Finethy, R., Coers, J.: Sensing the enemy, containing the threat: cell-autonomous immunity to Chlamydia trachomatis. FEMS Microbiol. Rev. 40, 875-893 (2016). doi:10.1093/femsre/fuw027

72. Byrne, G.I., Lehmann, L.K., Landry, G.J.: Induction of tryptophan catabolism is the mechanism for gamma-interferon-mediated inhibition of intracellular Chlamydia psittaci replication in T24 cells. Infect. Immun. 53, 347-351 (1986)

73. Roshick, C., Wood, H., Caldwell, H.D., McClarty, G.: Comparison of gamma interferonmediated antichlamydial defense mechanisms in human and mouse cells. Infect. Immun. 74, 225-238 (2006). doi:10.1128/IAI.74.1.225-238.2006

74. Nelson, D.E., Virok, D.P., Wood, H., Roshick, C., Johnson, R.M., Whitmire, W.M., Crane, D.D., Steele-Mortimer, O., Kari, L., McClarty, G., Caldwell, H.D.: Chlamydial IFN-gamma immune evasion is linked to host infection tropism. Proc. Natl. Acad. Sci. U. S. A. 102, 10658-10663 (2005). doi:10.1073/pnas.0504198102

75. Coers, J., Bernstein-Hanley, I., Grotsky, D., Parvanova, I., Howard, J.C., Taylor, G.A., Dietrich, W.F., Starnbach, M.N.: Chlamydia muridarum evades growth restriction by the IFN-gamma-inducible host resistance factor Irgb10. J. Immunol. Baltim. Md 1950. 180, 6237-6245 (2008)

76. WHO $\mid$ An estimate of the global prevalence and incidence of herpes simplex virus type 2 infection, https://www.who.int/bulletin/volumes/86/10/07-046128/en/

77. Gottlieb, S.L., Johnston, C.: Future prospects for new vaccines against sexually transmitted infections. Curr. Opin. Infect. Dis. 30, 77-86 (2017). doi:10.1097/QCO.0000000000000343

78. Rechenchoski, D.Z., Faccin-Galhardi, L.C., Linhares, R.E.C., Nozawa, C.: Herpesvirus: an underestimated virus. Folia Microbiol. (Praha). 62, 151-156 (2017). doi:10.1007/s12223-016-0482-7

79. Johnston, C., Zhu, J., Jing, L., Laing, K.J., McClurkan, C.M., Klock, A., Diem, K., Jin, L., Stanaway, J., Tronstein, E., Kwok, W.W., Huang, M.-L., Selke, S., Fong, Y., Magaret, A., Koelle, D.M., Wald, A., Corey, L.: Virologic and immunologic evidence of multifocal genital herpes simplex virus 2 infection. J. Virol. 88, 4921-4931 (2014). doi:10.1128/JVI.03285-13

80. Zimmer, B., Ewaleifoh, O., Harschnitz, O., Lee, Y.-S., Peneau, C., McAlpine, J.L., Liu, B., Tchieu, J., Steinbeck, J.A., Lafaille, F., Volpi, S., Notarangelo, L.D., Casanova, J.-L., Zhang, S.-Y., Smith, G.A., Studer, L.: Human iPSC-derived trigeminal neurons lack constitutive TLR3-dependent immunity that protects cortical neurons from HSV-1 infection. Proc. Natl. Acad. Sci. U. S. A. 115, E8775-E8782 (2018). doi:10.1073/pnas.1809853115

81. Whitley, R.J.: Herpesviruses. In: Baron, S. (ed.) Medical Microbiology. University of Texas Medical Branch at Galveston, Galveston (TX) (1996) 
82. Sauerbrei, A.: Herpes Genitalis: Diagnosis, Treatment and Prevention. Geburtshilfe Frauenheilkd. 76, 1310-1317 (2016). doi:10.1055/s-0042-116494

83. Bernstein, D.I., Bellamy, A.R., Hook, E.W., Levin, M.J., Wald, A., Ewell, M.G., Wolff, P.A., Deal, C.D., Heineman, T.C., Dubin, G., Belshe, R.B.: Epidemiology, clinical presentation, and antibody response to primary infection with herpes simplex virus type 1 and type 2 in young women. Clin. Infect. Dis. Off. Publ. Infect. Dis. Soc. Am. 56, 344351 (2013). doi:10.1093/cid/cis891

84. Kaufman, R.H., Gardner, H.L., Rawls, W.E., Dixon, R.E., Young, R.L.: Clinical Features of Herpes Genitalis. Cancer Res. 33, 1446-1451 (1973)

85. Ng, A.B.P., Reagan, J.W., Yen, S.S.C.: HERPES GENITALIS: Clinical and Cytopathologic Experience with 256 Patients. Obstet. Gynecol. 36, 645 (1970)

86. Recovery of Herpes Simplex Virus from Human Sacral Ganglions | NEJM, https://www.nejm.org/doi/pdf/10.1056/NEJM197410172911606

87. Wald, A., Zeh, J., Selke, S., Ashley, R.L., Corey, L.: Virologic Characteristics of Subclinical and Symptomatic Genital Herpes Infections. N. Engl. J. Med. 333, 770-775 (1995). doi:10.1056/NEJM199509213331205

88. Rattray, M.C., Corey, L., Reeves, W.C., Vontver, L.A., Holmes, K.K.: Recurrent genital herpes among women: symptomatic v. asymptomatic viral shedding. Sex. Transm. Infect. 54, 262-265 (1978). doi:10.1136/sti.54.4.262

89. Witzleben, C.L., Driscoll, S.G.: Possible Transplacental Transmission of Herpes Simplex Infection. Pediatrics. 36, 192-199 (1965)

90. Baldwin, S., Whitley, R.J.: Intrauterine herpes simplex virus infection. Teratology. 39, 110 (1989). doi:10.1002/tera.1420390102

91. Manavi, M., Czerwenka, K.F., Schurz, B., Knogler, W., Kubista, E., Reinold, E.: [Latent cervical virus infection as a possible cause of early abortion]. Gynakol. Geburtshilfliche Rundsch. 32, 84-87 (1992). doi:10.1159/000271851

92. Li, J.-M., Chen, Y.-R., Li, X.-T., Xu, W.-C.: Screening of Herpes simplex virus 2 infection among pregnant women in southern China. J. Dermatol. 38, 120-124 (2011). doi:10.1111/j.1346-8138.2010.00966.x

93. Levitz, R.E.: Herpes simplex encephalitis: A review. Heart Lung. 27, 209-212 (1998). doi:10.1016/S0147-9563(98)90009-7

94. Straface, G., Selmin, A., Zanardo, V., De Santis, M., Ercoli, A., Scambia, G.: Herpes Simplex Virus Infection in Pregnancy. Infect. Dis. Obstet. Gynecol. 2012, (2012). doi:10.1155/2012/385697

95. DRUGS \& DISEASE: Treating Herpes Keratitis: The New State of the Art, http://epubs.democratprinting.com/article/DRUGS+\%26+DISEASE\%3A+Treating+Herp es+Keratitis\%3A+The+New+State+of+the+Art/765149/72752/article.html

96. Piret, J., Boivin, G.: Resistance of herpes simplex viruses to nucleoside analogues: mechanisms, prevalence, and management. Antimicrob. Agents Chemother. 55, 459-472 (2011). doi:10.1128/AAC.00615-10

97. Chakrabarty, A., Tyring, S.K., Beutner, K., Rauser, M.: Recent Clinical Experience with Famciclovir - A 'Third Generation' Nucleoside Prodrug. Antivir. Chem. Chemother. 15, 251-253 (2004). doi:10.1177/095632020401500503

98. Spruance, S.L., Stewart, J.C.B., Rowe, N.H., McKeough, M.B., Wenerstrom, G., Freeman, D.J.: Treatment of Recurrent Herpes Simplex Labialis with Oral Acyclovir. J. Infect. Dis. 161, 185-190 (1990). doi:10.1093/infdis/161.2.185

99. Desselberger, U.: Herpes simplex Virus Infection in Pregnancy: Diagnosis and Significance. Intervirology. 41, 185-190 (1998). doi:10.1159/000024934

100. Valaciclovir versus aciclovir for herpes simplex virus infection in HIV-infected individuals: two randomized trials. Int. J. STD AIDS. 13, 12-21 (2002). doi:10.1258/0956462021924550 
101. Hodge, R.A.V.: Famciclovir and Penciclovir. The Mode of Action of Famciclovir Including Its Conversion to Penciclovir. Antivir. Chem. Chemother. 4, 67-84 (1993). doi:10.1177/095632029300400201

102. Weinberg, A., Bate, B.J., Masters, H.B., Schneider, S.A., Clark, J.C., Wren, C.G., Allaman, J.A., Levin, M.J.: In vitro activities of penciclovir and acyclovir against herpes simplex virus types 1 and 2. Antimicrob. Agents Chemother. 36, 2037-2038 (1992). doi:10.1128/AAC.36.9.2037

103. Leary, J.J., Wittrock, R., Sarisky, R.T., Weinberg, A., Levin, M.J.: Susceptibilities of Herpes Simplex Viruses to Penciclovir and Acyclovir in Eight Cell Lines. Antimicrob. Agents Chemother. 46, 762-768 (2002). doi:10.1128/AAC.46.3.762-768.2002

104. Vikas, R., Prabhu, S.G., Mudgal, P.P., Shetty, U., Karunakaran, K., Jagadesh, A., Auti, A., Stansilaus, R.P., Nair, S., Arunkumar, G.: HSV susceptibility to acyclovir - genotypic and phenotypic characterization. Antivir. Ther. (2018). doi:10.3851/IMP3279

105. Morfin, F., Thouvenot, D.: Herpes simplex virus resistance to antiviral drugs. J. Clin. Virol. Off. Publ. Pan Am. Soc. Clin. Virol. 26, 29-37 (2003)

106. Field, H.J.: Herpes simplex virus antiviral drug resistance - current trends and future prospects. J. Clin. Virol. 21, 261-269 (2001). doi:10.1016/S1386-6532(00)00169-4

107. Brunnemann, A.-K., Hoffmann, A., Deinhardt-Emmer, S., Nagel, C.-H., Rose, R., Fickenscher, H., Sauerbrei, A., Krumbholz, A.: Relevance of non-synonymous thymidine kinase mutations for antiviral resistance of recombinant herpes simplex virus type 2 strains. Antiviral Res. 152, 53-57 (2018). doi:10.1016/j.antiviral.2018.02.004

108. Frobert, E., Burrel, S., Ducastelle-Lepretre, S., Billaud, G., Ader, F., Casalegno, J.-S., Nave, V., Boutolleau, D., Michallet, M., Lina, B., Morfin, F.: Resistance of herpes simplex viruses to acyclovir: an update from a ten-year survey in France. Antiviral Res. 111, 36-41 (2014). doi:10.1016/j.antiviral.2014.08.013

109. Gayretli Aydin, Z.G., Tanir, G., Genc Sel, C., Tasci Yıldız, Y., Aydin Teke, T., Kaman, A.: Acyclovir Unresponsive Herpes Simplex Encephalitis in a child successfully treated with the addition of Foscarnet: Case report. Arch. Argent. Pediatr. 117, e47-e51 (2019). doi:10.5546/aap.2019.eng.e47

110. Martinez, C.M., Luks-Golger, D.B.: Cidofovir use in acyclovir-resistant herpes infection. Ann. Pharmacother. 31, 1519-1521 (1997)

111. Cagno, V., Tintori, C., Civra, A., Cavalli, R., Tiberi, M., Botta, L., Brai, A., Poli, G., Tapparel, C., Lembo, D., Botta, M.: Novel broad spectrum virucidal molecules against enveloped viruses. PloS One. 13, e0208333 (2018). doi:10.1371/journal.pone.0208333

112. Silva-Mares, D., Torres-López, E., Rivas-Galindo, V.M.: Antiherpetic Plants: A Review of Active Extracts, Isolated Compounds, and Bioassays. Nat. Prod. Commun. 11, 557566 (2016)

113. Sharifi-Rad, J., Iriti, M., Setzer, W.N., Sharifi-Rad, M., Roointan, A., Salehi, B.: Antiviral activity of Veronica persica Poir. on herpes virus infection. Cell. Mol. Biol. Noisy--Gd. Fr. 64, 11-17 (2018)

114. Schnitzler, P., Reichling, J.: [Efficacy of plant products against herpetic infections]. HNO. 59, 1176-1184 (2011). doi:10.1007/s00106-010-2253-0

115. Hassan, S.T.S., Masarčíková, R., Berchová, K.: Bioactive natural products with antiherpes simplex virus properties. J. Pharm. Pharmacol. 67, 1325-1336 (2015). doi:10.1111/jphp.12436

116. Crumpacker, C.S., Schaffer, P.A.: New anti-HSV therapeutics target the helicase-primase complex. Nat. Med. 8, 327 (2002). doi:10.1038/nm0402-327

117. Kleymann, G., Fischer, R., Betz, U.A.K., Hendrix, M., Bender, W., Schneider, U., Handke, G., Eckenberg, P., Hewlett, G., Pevzner, V., Baumeister, J., Weber, O., Henninger, K., Keldenich, J., Jensen, A., Kolb, J., Bach, U., Popp, A., Mäben, J., Frappa, I., Haebich, D., Lockhoff, O., Rübsamen-Waigmann, H.: New helicase-primase inhibitors 
as drug candidates for the treatment of herpes simplex disease. Nat. Med. 8, 392 (2002). doi:10.1038/nm0402-392

118. Collot, M., Rouard, C., Brunet, C., Agut, H., Boutolleau, D., Burrel, S.: High conservation of herpes simplex virus UL5/UL52 helicase-primase complex in the era of new antiviral therapies. Antiviral Res. 128, 1-6 (2016).

doi:10.1016/j.antiviral.2016.01.015

119. Shin, H., Iwasaki, A.: A vaccine strategy that protects against genital herpes by establishing local memory T cells. Nature. 491, 463-467 (2012). doi:10.1038/nature11522

120. Stanberry, L.R., Spruance, S.L., Cunningham, A.L., Bernstein, D.I., Mindel, A., Sacks, S., Tyring, S., Aoki, F.Y., Slaoui, M., Denis, M., Vandepapeliere, P., Dubin, G.: Glycoprotein-D-Adjuvant Vaccine to Prevent Genital Herpes. N. Engl. J. Med. 347, 1652-1661 (2002). doi:10.1056/NEJMoa011915

121. Burian, K., Endresz, V., Deak, J., Kormanyos, Z., Pal, A., Nelson, D., Virok, D.P.: Transcriptome Analysis Indicates an Enhanced Activation of Adaptive and Innate Immunity by Chlamydia-Infected Murine Epithelial Cells Treated with Interferon $\gamma . \mathrm{J}$. Infect. Dis. 202, 1405-1414 (2010). doi:10.1086/656526

122. Caldwell, H.D., Kromhout, J., Schachter, J.: Purification and partial characterization of the major outer membrane protein of Chlamydia trachomatis. Infect. Immun. 31, 1161$1176(1981)$

123. European Pharmacopoeia (Ph. Eur.) 9th Edition |EDQM, https://www.edqm.eu/en/european-pharmacopoeia-ph-eur-9th-edition

124. Owen, D.H., Katz, D.F.: A vaginal fluid simulant. Contraception. 59, 91-95 (1999)

125. Bogdanov, A., Janovák, L., Lantos, I., Endrész, V., Sebők, D., Szabó, T., Dékány, I., Deák, J., Rázga, Z., Burián, K., Virok, D.P.: Nonactivated titanium-dioxide nanoparticles promote the growth of Chlamydia trachomatis and decrease the antimicrobial activity of silver nanoparticles. J. Appl. Microbiol. 123, 1335-1345 (2017). doi:10.1111/jam.13560

126. Osaka, I., Hills, J.M., Kieweg, S.L., Shinogle, H.E., Moore, D.S., Hefty, P.S.: An Automated Image-Based Method for Rapid Analysis of Chlamydia Infection as a Tool for Screening Antichlamydial Agents. Antimicrob. Agents Chemother. 56, 4184-4188 (2012). doi:10.1128/AAC.00427-12

127. Lundholt, B.K., Scudder, K.M., Pagliaro, L.: A Simple Technique for Reducing Edge Effect in Cell-Based Assays. J. Biomol. Screen. 8, 566-570 (2003). doi:10.1177/1087057103256465

128. Hua-Feng, X., Yue-Ming, W., Hong, L., Junyi, D.: A meta-analysis of the association between Chlamydia pneumoniae infection and lung cancer risk. Indian J. Cancer. 52 Suppl 2, e112-115 (2015). doi:10.4103/0019-509X.172506

129. Bogdanov, A., Endrész, V., Urbán, S., Lantos, I., Deák, J., Burián, K., Önder, K., Ayaydin, F., Balázs, P., Virok, D.P.: Application of DNA chip scanning technology for automatic detection of Chlamydia trachomatis and Chlamydia pneumoniae inclusions. Antimicrob. Agents Chemother. 58, 405-413 (2014). doi:10.1128/AAC.01400-13

130. Santamaría, R., Pierre, P.: Voronto: mapper for expression data to ontologies. Bioinforma. Oxf. Engl. 28, 2281-2282 (2012). doi:10.1093/bioinformatics/bts428

131. Statistical analysis of real-time PCR data. - PubMed - NCBI, https://www.ncbi.nlm.nih.gov/pubmed/16504059

132. Veres, G., Molnár, M., Zádori, D., Szentirmai, M., Szalárdy, L., Török, R., Fazekas, E., Ilisz, I., Vécsei, L., Klivényi, P.: Central nervous system-specific alterations in the tryptophan metabolism in the 3-nitropropionic acid model of Huntington's disease. Pharmacol. Biochem. Behav. 132, 115-124 (2015). doi:10.1016/j.pbb.2015.03.002

133. R Core Team: R: A Language and Environment for Statistical Computing. R Foundation for Statistical Computing, Vienna, Austria (2014) 
134. Mucsi, I., Molnár, J., Motohashi, N.: Combination of benzo[a]phenothiazines with acyclovir against herpes simplex virus. Int. J. Antimicrob. Agents. 18, 67-72 (2001). doi:10.1016/S0924-8579(01)00323-5

135. Párducz, L., Eszik, I., Wagner, G., Burián, K., Endrész, V., Virok, D.P.: Impact of antiseptics on Chlamydia trachomatis growth. Lett. Appl. Microbiol. 63, 260-267 (2016). doi:10.1111/lam.12625

136. Virók, D.P., Eszik, I., Mosolygó, T., Önder, K., Endrész, V., Burián, K.: A direct quantitative PCR-based measurement of herpes simplex virus susceptibility to antiviral drugs and neutralizing antibodies. J. Virol. Methods. 242, 46-52 (2017). doi:10.1016/j.jviromet.2017.01.007

137. Kis, Z., Burian, K., Treso, B., Acs, K., Prohaszka, Z., Fust, G., Gonczol, E., Endresz, V.: Inflammatory- and immune responses in relation to bacterial replication in mice following re-infections with Chlamydophila pneumoniae. Inflamm. Res. 57, 287-295 (2008). doi:10.1007/s00011-007-7124-0

138. Kis, Z., Burian, K., Treso, B., Acs, K., Prohaszka, Z., Fust, G., Gonczol, E., Endresz, V.: Inflammatory- and immune responses in relation to bacterial replication in mice following re-infections with Chlamydophila pneumoniae. Inflamm. Res. Off. J. Eur. Histamine Res. Soc. Al. 57, 287-295 (2008). doi:10.1007/s00011-007-7124-0

139. Kuleshov, M.V., Jones, M.R., Rouillard, A.D., Fernandez, N.F., Duan, Q., Wang, Z., Koplev, S., Jenkins, S.L., Jagodnik, K.M., Lachmann, A., McDermott, M.G., Monteiro, C.D., Gundersen, G.W., Ma'ayan, A.: Enrichr: a comprehensive gene set enrichment analysis web server 2016 update. Nucleic Acids Res. 44, W90-97 (2016). doi:10.1093/nar/gkw377

140. Bernstein-Hanley, I., Coers, J., Balsara, Z.R., Taylor, G.A., Starnbach, M.N., Dietrich, W.F.: The p47 GTPases Igtp and Irgb10 map to the Chlamydia trachomatis susceptibility locus Ctrq-3 and mediate cellular resistance in mice. Proc. Natl. Acad. Sci. U. S. A. 103, 14092-14097 (2006). doi:10.1073/pnas.0603338103

141. Bernstein-Hanley, I., Balsara, Z.R., Ulmer, W., Coers, J., Starnbach, M.N., Dietrich, W.F.: Genetic analysis of susceptibility to Chlamydia trachomatis in mouse. Genes Immun. 7, 122-129 (2006). doi:10.1038/sj.gene.6364285

142. Thorvaldsdóttir, H., Robinson, J.T., Mesirov, J.P.: Integrative Genomics Viewer (IGV): high-performance genomics data visualization and exploration. Brief. Bioinform. 14, 178-192 (2013). doi:10.1093/bib/bbs017

143. Nelson, D.E., Virok, D.P., Wood, H., Roshick, C., Johnson, R.M., Whitmire, W.M., Crane, D.D., Steele-Mortimer, O., Kari, L., McClarty, G., Caldwell, H.D.: Chlamydial IFN-gamma immune evasion is linked to host infection tropism. Proc. Natl. Acad. Sci. U. S. A. 102, 10658-10663 (2005). doi:10.1073/pnas.0504198102

144. Roshick, C., Wood, H., Caldwell, H.D., McClarty, G.: Comparison of gamma interferonmediated antichlamydial defense mechanisms in human and mouse cells. Infect. Immun. 74, 225-238 (2006). doi:10.1128/IAI.74.1.225-238.2006

145. Orbán-Gyapai, O., Liktor-Busa, E., Kúsz, N., Stefkó, D., Urbán, E., Hohmann, J., Vasas, A.: Antibacterial screening of Rumex species native to the Carpathian Basin and bioactivity-guided isolation of compounds from Rumex aquaticus. Fitoterapia. 118, 101106 (2017). doi:10.1016/j.fitote.2017.03.009

146. Gescher, K., Hensel, A., Hafezi, W., Derksen, A., Kühn, J.: Oligomeric proanthocyanidins from Rumex acetosa L. inhibit the attachment of herpes simplex virus type-1. Antiviral Res. 89, 9-18 (2011). doi:10.1016/j.antiviral.2010.10.007

147. Sater, A.A.A., Ojcius, D.M., Meyer, M.P.: Susceptibility of Chlamydia trachomatis to the excipient hydroxyethyl cellulose: $\mathrm{pH}$ and concentration dependence of antimicrobial activity. Antimicrob. Agents Chemother. 52, 2660-2662 (2008). doi:10.1128/AAC.00785-07 
148. Gao, Y., Yuan, A., Chuchuen, O., Ham, A., Yang, K.H., Katz, D.F.: Vaginal deployment and tenofovir delivery by microbicide gels. Drug Deliv. Transl. Res. 5, 279-294 (2015). doi:10.1007/s13346-015-0227-1

149. Thomson, N.R., Holden, M.T.G., Carder, C., Lennard, N., Lockey, S.J., Marsh, P., Skipp, P., O’Connor, C.D., Goodhead, I., Norbertzcak, H., Harris, B., Ormond, D., Rance, R., Quail, M.A., Parkhill, J., Stephens, R.S., Clarke, I.N.: Chlamydia trachomatis: Genome sequence analysis of lymphogranuloma venereum isolates. Genome Res. 18, 161-171 (2008). doi:10.1101/gr.7020108

150. Davis, C.H., Wyrick, P.B.: Differences in the association of Chlamydia trachomatis serovar E and serovar L2 with epithelial cells in vitro may reflect biological differences in vivo. Infect. Immun. 65, 2914-2924 (1997)

151. Kuo, C.C., Grayston, T.: Interaction of Chlamydia trachomatis organisms and HeLa 229 cells. Infect. Immun. 13, 1103-1109 (1976)

152. Hegemann, J.H., Moelleken, K.: Chlamydial Adhesion and Adhesins. Intracell. Pathog. Chlamydiales. 97-125 (2012). doi:10.1128/9781555817329.ch5

153. Stephens, R.S.: The cellular paradigm of chlamydial pathogenesis. Trends Microbiol. 11, 44-51 (2003)

154. Burian, K., Endresz, V., Deak, J., Kormanyos, Z., Pal, A., Nelson, D., Virok, D.P.: Transcriptome analysis indicates an enhanced activation of adaptive and innate immunity by chlamydia-infected murine epithelial cells treated with interferon $\gamma$. J. Infect. Dis. 202, 1405-1414 (2010). doi:10.1086/656526

155. Coers, J., Bernstein-Hanley, I., Grotsky, D., Parvanova, I., Howard, J.C., Taylor, G.A., Dietrich, W.F., Starnbach, M.N.: Chlamydia muridarum evades growth restriction by the IFN-gamma-inducible host resistance factor Irgb10. J. Immunol. Baltim. Md 1950. 180, $6237-6245(2008)$

156. Johnson, R.M., Kerr, M.S., Slaven, J.E.: Plac8-dependent and inducible NO synthasedependent mechanisms clear Chlamydia muridarum infections from the genital tract. J. Immunol. Baltim. Md 1950. 188, 1896-1904 (2012). doi:10.4049/jimmunol.1102764

157. Rajaram, K., Nelson, D.E.: Chlamydia muridarum Infection of Macrophages Elicits Bactericidal Nitric Oxide Production via Reactive Oxygen Species and Cathepsin B. Infect. Immun. 83, 3164-3175 (2015). doi:10.1128/IAI.00382-15

158. Tallam, A., Perumal, T.M., Antony, P.M., Jäger, C., Fritz, J.V., Vallar, L., Balling, R., Sol, A. del, Michelucci, A.: Gene Regulatory Network Inference of Immunoresponsive Gene 1 (IRG1) Identifies Interferon Regulatory Factor 1 (IRF1) as Its Transcriptional Regulator in Mammalian Macrophages. PLOS ONE. 11, e0149050 (2016). doi:10.1371/journal.pone.0149050

159. Naujoks, J., Tabeling, C., Dill, B.D., Hoffmann, C., Brown, A.S., Kunze, M., Kempa, S., Peter, A., Mollenkopf, H.-J., Dorhoi, A., Kershaw, O., Gruber, A.D., Sander, L.E., Witzenrath, M., Herold, S., Nerlich, A., Hocke, A.C., van Driel, I., Suttorp, N., Bedoui, S., Hilbi, H., Trost, M., Opitz, B.: IFNs Modify the Proteome of Legionella-Containing Vacuoles and Restrict Infection Via IRG1-Derived Itaconic Acid. PLoS Pathog. 12, e1005408 (2016). doi:10.1371/journal.ppat.1005408

160. Hall, C.J., Boyle, R.H., Astin, J.W., Flores, M.V., Oehlers, S.H., Sanderson, L.E., Ellett, F., Lieschke, G.J., Crosier, K.E., Crosier, P.S.: Immunoresponsive Gene 1 Augments Bactericidal Activity of Macrophage-Lineage Cells by Regulating $\beta$-OxidationDependent Mitochondrial ROS Production. Cell Metab. 18, 265-278 (2013). doi:10.1016/j.cmet.2013.06.018

161. Cole, A.M., Ganz, T., Liese, A.M., Burdick, M.D., Liu, L., Strieter, R.M.: Cutting edge: IFN-inducible ELR- CXC chemokines display defensin-like antimicrobial activity. J. Immunol. Baltim. Md 1950. 167, 623-627 (2001). doi:10.4049/jimmunol.167.2.623

162. Balogh, E.P., Faludi, I., Virók, D.P., Endrész, V., Burián, K.: Chlamydophila pneumoniae induces production of the defensin-like MIG/CXCL9, which has in vitro antichlamydial 
activity. Int. J. Med. Microbiol. IJMM. 301, 252-259 (2011).

doi:10.1016/j.ijmm.2010.08.020

163. Loughman, J.A., Hunstad, D.A.: Induction of Indoleamine 2,3-Dioxygenase by Uropathogenic Bacteria Attenuates Innate Responses to Epithelial Infection. J. Infect. Dis. 205, 1830-1839 (2012). doi:10.1093/infdis/jis280

164. Sanni, L.A., Thomas, S.R., Tattam, B.N., Moore, D.E., Chaudhri, G., Stocker, R., Hunt, N.H.: Dramatic changes in oxidative tryptophan metabolism along the kynurenine pathway in experimental cerebral and noncerebral malaria. Am. J. Pathol. 152, 611-619 (1998)

165. Fujigaki, S., Saito, K., Takemura, M., Maekawa, N., Yamada, Y., Wada, H., Seishima, M.: L-tryptophan-L-kynurenine pathway metabolism accelerated by Toxoplasma gondii infection is abolished in gamma interferon-gene-deficient mice: cross-regulation between inducible nitric oxide synthase and indoleamine-2,3-dioxygenase. Infect. Immun. 70, 779-786 (2002)

166. Rottenberg, M.E., Gigliotti Rothfuchs, A., Gigliotti, D., Ceausu, M., Une, C., Levitsky, V., Wigzell, H.: Regulation and role of IFN-gamma in the innate resistance to infection with Chlamydia pneumoniae. J. Immunol. Baltim. Md 1950. 164, 4812-4818 (2000). doi:10.4049/jimmunol.164.9.4812

167. Schmid, M., Lehmann, M.J., Lucius, R., Gupta, N.: Apicomplexan parasite, Eimeria falciformis, co-opts host tryptophan catabolism for life cycle progression in mouse. J. Biol. Chem. 287, 20197-20207 (2012). doi:10.1074/jbc.M112.351999

168. Huang, L., Li, L., Klonowski, K.D., Tompkins, S.M., Tripp, R.A., Mellor, A.L.: Induction and role of indoleamine 2,3 dioxygenase in mouse models of influenza a virus infection. PloS One. 8, e66546 (2013). doi:10.1371/journal.pone.0066546

169. Desvignes, L., Ernst, J.D.: Interferon-gamma-responsive nonhematopoietic cells regulate the immune response to Mycobacterium tuberculosis. Immunity. 31, 974-985 (2009). doi:10.1016/j.immuni.2009.10.007

170. Blumenthal, A., Nagalingam, G., Huch, J.H., Walker, L., Guillemin, G.J., Smythe, G.A., Ehrt, S., Britton, W.J., Saunders, B.M.: M. tuberculosis Induces Potent Activation of IDO-1, but This Is Not Essential for the Immunological Control of Infection. PLOS ONE. 7, e37314 (2012). doi:10.1371/journal.pone.0037314

171. Mellor, A.L., Baban, B., Chandler, P., Marshall, B., Jhaver, K., Hansen, A., Koni, P.A., Iwashima, M., Munn, D.H.: Cutting Edge: Induced Indoleamine 2,3 Dioxygenase Expression in Dendritic Cell Subsets Suppresses T Cell Clonal Expansion. J. Immunol. 171, 1652-1655 (2003). doi:10.4049/jimmunol.171.4.1652

172. Cady, S.G., Sono, M.: 1-Methyl-DL-tryptophan, beta-(3-benzofuranyl)-DL-alanine (the oxygen analog of tryptophan), and beta-[3-benzo(b)thienyl]-DL-alanine (the sulfur analog of tryptophan) are competitive inhibitors for indoleamine 2,3-dioxygenase. Arch. Biochem. Biophys. 291, 326-333 (1991)

173. Metz, R., Duhadaway, J.B., Kamasani, U., Laury-Kleintop, L., Muller, A.J., Prendergast, G.C.: Novel tryptophan catabolic enzyme IDO2 is the preferred biochemical target of the antitumor indoleamine 2,3-dioxygenase inhibitory compound D-1-methyl-tryptophan. Cancer Res. 67, 7082-7087 (2007). doi:10.1158/0008-5472.CAN-07-1872

174. Beagley, K.W., Huston, W.M., Hansbro, P.M., Timms, P.: Chlamydial infection of immune cells: altered function and implications for disease. Crit. Rev. Immunol. 29, 275305 (2009)

175. Carlin, J.M., Weller, J.B.: Potentiation of interferon-mediated inhibition of Chlamydia infection by interleukin-1 in human macrophage cultures. Infect. Immun. 63, 1870-1875 (1995)

176. Nettelnbreker, E., Zeidler, H., Bartels, H., Dreses-Werringloer, U., Däubener, W., Holtmann, H., Köhler, L.: Studies of persistent infection by Chlamydia trachomatis 
serovar K in TPA-differentiated U937 cells and the role of IFN-gamma. J. Med. Microbiol. 47, 141-149 (1998). doi:10.1099/00222615-47-2-141

177. Koehler, L., Nettelnbreker, E., Hudson, A.P., Ott, N., Gérard, H.C., Branigan, P.J., Schumacher, H.R., Drommer, W., Zeidler, H.: Ultrastructural and molecular analyses of the persistence ofChlamydia trachomatis(serovar K) in human monocytes. Microb. Pathog. 22, 133-142 (1997). doi:10.1006/mpat.1996.0103

178. Marangoni, A., Bergamini, C., Fato, R., Cavallini, C., Donati, M., Nardini, P., Foschi, C., Cevenini, R.: Infection of human monocytes by Chlamydia pneumoniae and Chlamydia trachomatis: an in vitro comparative study. BMC Res. Notes. 7, 230 (2014).

doi:10.1186/1756-0500-7-230 


\section{Publications \\ related to this \\ thesis}




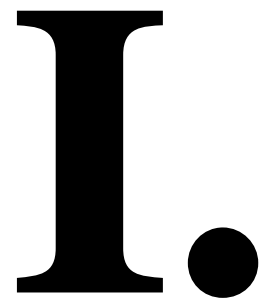




\title{
Vaginal Gel Component Hydroxyethyl Cellulose Significantly Enhances the Infectivity of Chlamydia trachomatis Serovars D and $E$
}

\author{
aDepartment of Medical Microbiology and Immunobiology, University of Szeged, Szeged, Hungary \\ bDepartment of Physical Chemistry and Materials Science, University of Szeged, Szeged, Hungary \\ cInstitute of Functional Microbial Genomics, Heinrich-Heine-University of Düsseldorf, Düsseldorf, Germany
}

Tímea Raffai, a Katalin Burián, ${ }^{a}$ László Janovák, ${ }^{b}$ Anita Bogdanov, ${ }^{a}$ Johannes H. Hegemann, ${ }^{c}$ Valéria Endrész, ${ }^{a}$ Dezső P. Virok ${ }^{a}$

\begin{abstract}
The transmission of the urogenital serovars of Chlamydia trachomatis can be significantly influenced by vaginal gels. Hydroxyethyl cellulose is a commonly used gelling agent that can be found in vaginal gels. Hydroxyethyl cellulose showed a concentration-dependent growth-enhancing effect on $C$. trachomatis serovars $D$ and $\mathrm{E}$, with a 26.1 -fold maximal increase in vitro and a 2.57 -fold increase in vivo.
\end{abstract}

KEYWORDS Chlamydia trachomatis, hydroxyethyl cellulose, infectivity, vaginal gel

- hlamydia trachomatis urogenital serovars D-K-related infections cause diseases

such as urethritis, cervicitis, and pelvic inflammatory disease, while serovars L1 and L2 are at the background of the less common disease lymphogranuloma venereum, a sexually transmitted infection with systemic rather than local manifestations. Among urogenital Chlamydia, serovars D and E are highly prevalent (1-3). C. trachomatis urogenital infections are globally among the most common sexually transmitted infections. For example, in 2016, 1,598,354 C. trachomatis infections were reported in the United States, and the number of reported infections steadily increased from 2000 to 2016 , reaching 497.3 cases per 100,000 people (4). The risk of Chlamydia transmission is greatly influenced by components of the cervicovaginal microenvironment, including vaginal lactobacilli and indole-positive bacteria (5). Vaginal gels can be introduced into this microenvironment as lubricants or therapeutic gels. Vaginal gels are present during sexual intercourse, and due to their spatial and temporal presence, these gels may have a significant impact on the acquisition of Chlamydia infection and other sexually transmitted diseases. A major component of vaginal gels is the gelling agent itself. Hydroxyethyl cellulose (HEC) is a commonly used gelling agent that can be found in lubricants and in therapeutic gels $(6,7)$. To elucidate the potential impact of HEC on chlamydial transmission, we tested the effect of HEC on the growth of C. trachomatis serovars $\mathrm{D}$ and $\mathrm{E}$.

HeLa 229 cells (ATCC) were placed into 96-well plates at a density of $4 \times 10^{4}$ cells/well in $100 \mu \mathrm{l}$ of minimal essential medium (MEM) with Earle's salts supplemented with $10 \%$ heat-inactivated fetal bovine serum, $2 \mathrm{mmol} /$ liter L-glutamine, $1 \times \mathrm{MEM}$ vitamins, $1 \times$ nonessential amino acids, $0.005 \%$ Na-pyruvate, $25 \mu \mathrm{g} / \mathrm{ml}$ gentamicin, and $1 \mu \mathrm{g} / \mathrm{ml}$ Fungizone. The next day, the $90 \%$ confluent cells were infected with $C$. trachomatis serovar D strain UW-3/CX (ATCC) and C. trachomatis serovar E strain DK20 (8). Before the infection, the chlamydial elementary bodies (EBs) were preincubated in HEC (European Pharmacopoeia 9.0 quality [9], Molar Chemicals, Halásztelek, Hungary) dissolved in vaginal simulant buffer [ $\mathrm{NaCl} 3.51 \mathrm{~g} / \mathrm{liter}, \mathrm{KOH} 1.40 \mathrm{~g} / \mathrm{liter}, \mathrm{Ca}(\mathrm{OH})_{2} 0.222 \mathrm{~g} /$ liter, bovine serum albumin $0.018 \mathrm{~g} /$ liter, lactic acid $2.00 \mathrm{~g} /$ liter, acetic acid $1.00 \mathrm{~g} /$ liter, glycerol $0.16 \mathrm{~g} /$ /iter, urea $0.4 \mathrm{~g} /$ /iter, glucose $5.0 \mathrm{~g} /$ liter] and vaginal simulant buffer

Citation Raffai T, Burián K, Janovák L, Bogdanov A, Hegemann JH, Endrész V, Virok DP. 2019. Vaginal gel component hydroxyethyl cellulose significantly enhances the infectivity of Chlamydia trachomatis serovars D and $\mathrm{E}$. Antimicrob Agents Chemother 63:e02034-18. https://doi.org/10.1128/AAC.02034-18. Copyright $\odot 2018$ American Society for Microbiology. All Rights Reserved. Address correspondence to Dezső P. Virok, virok.dezso.peter@med.u-szeged.hu. T.R. and K.B. contributed equally to this work. Received 21 September 2018 Returned for modification 9 October 2018 Accepted 22 October 2018

Accepted manuscript posted online 29 October 2018

Published 21 December 2018 
A

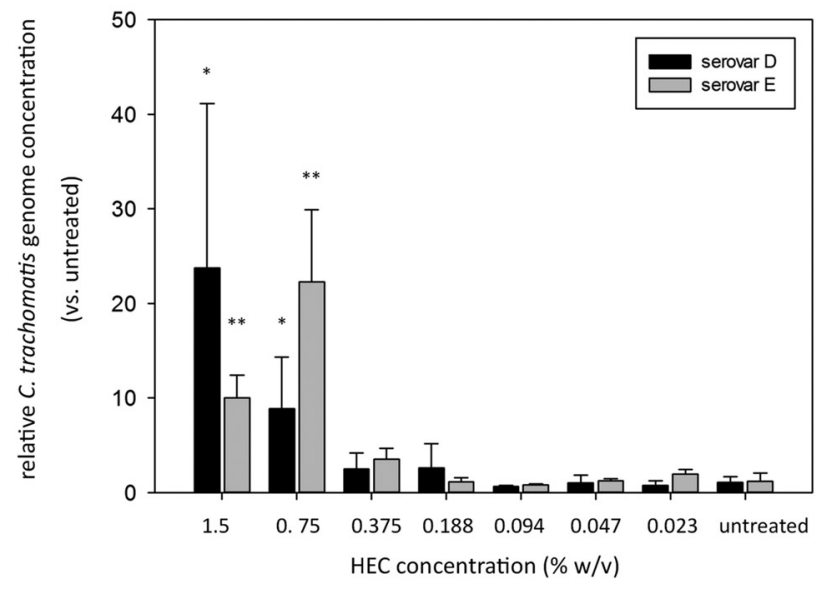

B

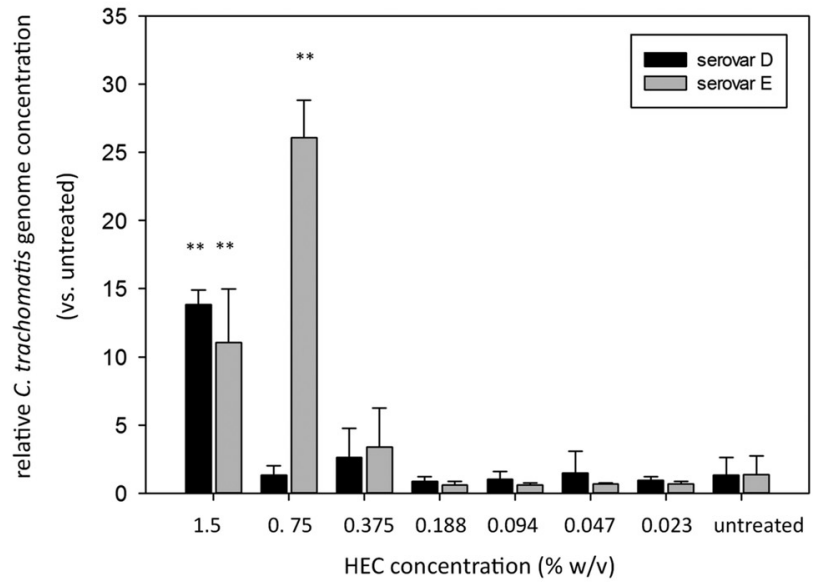

D

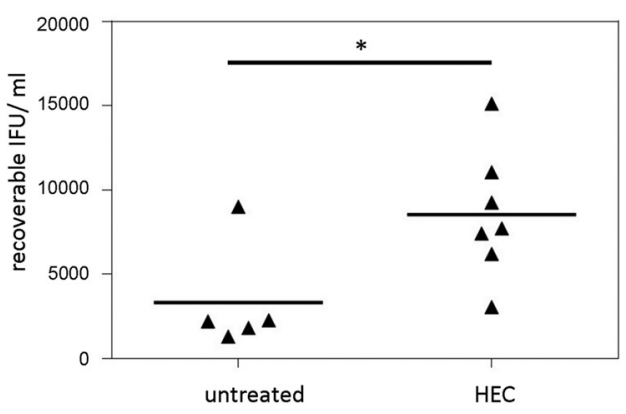

FIG 1 Impact of HEC on the growth of C. trachomatis serovars D and E in HeLa 229 cells in vitro at pH 4.2 (A) and pH 7 (B). Bacterial genome copy numbers were measured by direct qPCR $(n=3)$. The qPCR data were validated by the ChlamyCount immunofluorescent automatic inclusion counting system ( $n=4)$. (C) The images of the ChlamyCount-processed wells and the counted inclusion numbers. (D) Recoverable $C$. trachomatis serovar D IFU in cervicovaginal swab samples 3 days postinfection. Mice were infected intravaginally with $C$. trachomatis serovar D mixed with HEC $(1.5 \%$ wt/vol) $(n=7)$ or without HEC ( $n=5)$. Data are means \pm standard deviations. ${ }^{*}, P<0.05 ;{ }^{* *}, P<0.01$, according to Student's $t$ test.

alone as a control, for $1 \mathrm{~h}$ at $37^{\circ} \mathrm{C}, 5 \% \mathrm{CO}_{2}$ (10). The $\mathrm{HEC}$ solutions were prepared by dissolving $30 \mathrm{mg}$ of the HEC polymers in $1 \mathrm{ml}$ vaginal simulant, followed by 2-fold dilutions (the applied HEC concentration range was $1.5-0.023 \% \mathrm{wt} / \mathrm{vol}$ ). The $\mathrm{pH}$ of the vaginal simulant was adjusted to $\mathrm{aH}$ of 4.2 or 7.0 . The preincubated inocula were suspended in MEM supplemented with $0.5 \% \mathrm{wt} / \mathrm{vol}$ glucose, and the cells were infected at a multiplicity of infection of 8 for $60 \mathrm{~min}$ at $37^{\circ} \mathrm{C}, 5 \% \mathrm{CO}_{2}$, without centrifugation. After infection, the cells were washed twice with phosphate-buffered saline, and a culture medium containing $0.1 \mu \mathrm{g} / \mathrm{ml}$ cycloheximide was added. After $48 \mathrm{~h}$ incubation, the chlamydial genomic content was measured by quantitative PCR (qPCR) as described previously (11), and the chlamydial inclusion count was measured by standard manual or automatic ChlamyCount immunofluorescent inclusion counting, as published earlier (12). Statistical evaluation of qPCR data was performed as described previously (11). All reagents were purchased from Sigma *St. Louis, MO), unless otherwise indicated.

To better mimic the cervicovaginal environment, we used the vaginal simulant to dilute HEC and incubate $C$. trachomatis EBs. The $\mathrm{pH}$ of the vaginal simulant was adjusted to 4.2 or 7 to mimic the normal and elevated pHs of the cervicovaginal tract. Figure $1 \mathrm{~A}$ shows HEC concentration-dependent enhancement of chlamydial growth after the preincubation of $C$. trachomatis EBs in $\mathrm{pH} 4.2$ vaginal fluid measured by $\mathrm{qPCR}$ $48 \mathrm{~h}$ postinfection. The $C$. trachomatis serovar $\mathrm{D}$ maximum growth increase was 23.7-fold at the maximal $1.5 \% \mathrm{wt} / \mathrm{vol}$ HEC concentration, and a noticeable but nonsig- 
nificant growth enhancement tendency could be detected up to a concentration of $0.188 \% \mathrm{wt} / \mathrm{vol} \mathrm{HEC}$. HEC at $\mathrm{pH} 7$ enhanced the chlamydial growth significantly, with a 13.8-fold growth increase at a concentration of $1.5 \% \mathrm{wt} / \mathrm{vol}$ (Fig. 1B). Interestingly, in the case of $C$. trachomatis serovar $E$, the maximum growth increase (22.25- and 26.1-fold at $\mathrm{pH} 4.2$ and 7, respectively) was observed at the second-highest HEC concentration ( $0.75 \% \mathrm{wt} / \mathrm{vol})$ at $\mathrm{pH} 4.2$ and 7, indicating a different HEC-EB interaction between the serovars (Fig. $1 \mathrm{~A}$ and $\mathrm{B}$ ). To validate the $\mathrm{qPCR}$ results, we performed the automatic Chlamydia inclusion counting using the ChlamyCount measuring system, at $\mathrm{pH} 4.2$ or 7 at $1.5 \% \mathrm{wt} / \mathrm{vol}$ and $0.75 \% \mathrm{wt} / \mathrm{vol}$ HEC concentrations for serovar D and serovar E, respectively. Inclusion counts showed similar albeit less growth enhancement than the chlamydial genome measurements by qPCR, with a 5.9- to 6.5-fold increase for serovar D and a 5.95- to 6.05-fold increase for serovar E (Fig. 1C). This difference is likely due to the fact that ChlamyCount measures the chlamydial inclusion number, whereas qPCR measures the bacterial genome content of the inclusions.

To monitor the effect of HEC in vivo, 6- to 8-week-old female BALB/c mice were treated subcutaneously with $2.5 \mathrm{mg}$ medroxyprogesterone acetate (Pfizer, Budapest, Hungary) 1 week before infection. Mice were inoculated intravaginally with $1 \times 10^{5}$ inclusion forming units (IFUs) of $C$. trachomatis serovar D mixed with HEC ( $1.5 \% \mathrm{wt} / \mathrm{vol})$ or without HEC, and recoverable IFUs in cervicovaginal washing 3 days postinfection were counted by using traditional immunofluorescence microscopy (12) (Fig. 1D). All experiments were approved by the Animal Welfare Committee of the University of Szeged and conformed to directive 2010/63/EU of the European Parliament. The in vivo data also showed that HEC significantly increased the growth of $C$. trachomatis serovar $D$ in the mouse genital tract, with a 2.57 -fold enhancement 3 days postinfection. It is important to note that the chlamydial EBs were not preincubated with HEC before infection, indicating an immediate growth-enhancing effect of HEC in vivo.

Interestingly, our results differ from those of Sater et al. (13), who used the lymphogranuloma venereum strain C. trachomatis L2 and showed concentration- and $\mathrm{pH}$-dependent inhibitory effects of HEC on chlamydial growth in vitro. However, there are important differences between the two studies, including the fact that we used a complex buffer that may better mimic the physicochemical properties of the vaginal fluid than the phosphate and acetate buffers used by Sater et al. Moreover, we observed the growthenhancing effect at $0.75 \%$ to $1.5 \% \mathrm{wt} / \mathrm{vol}(7,500-15,000 \mu \mathrm{g} / \mathrm{ml}) \mathrm{HEC}$ concentrations, which are common in the vaginal gels $(7,14)$, whereas Sater et al. used significantly lower HEC concentrations $(2-200 \mu \mathrm{g} / \mathrm{ml})$. Instead of serovar $\mathrm{L} 2$, we also used the more prevalent urogenital serovars $\mathrm{D}$ and $\mathrm{E}$. While $C$. trachomatis $\mathrm{D}$ and $\mathrm{L} 2$ have minor genetic differences (15), there are several phenotypic differences between the two serotypes. Previous studies showed that their early interactions with epithelial cells are different $(16,17)$, including the fact that centrifugation and dextran pretreatment of host epithelial cells increased the infection efficacy of urogenital $C$. trachomatis serovars but had no impact on serovar $L 2$. In addition, serovar E infection is heparin independent, whereas serovar L2 infection exhibits a strong heparin dependency (18). Because HEC probably influences the early interactions between the EBs and the host cells, this effect may be different between the lymphogranuloma venereum and urogenital serovars.

Altogether, our study shows that vaginal gel components, such as the gelling agent HEC, have a significant growth-enhancing effect on two prevalent $C$. trachomatis urogenital serovars. This enhancing effect was observed in vitro over a wide range of $\mathrm{pHs}$, at lower concentrations, and in vivo. Because the growth enhancement can theoretically lower the minimal number of bacteria required for infection transmission, these results suggest the need for testing current and future vaginal gels to determine their growthenhancing effects on C. trachomatis and on other sexually transmitted pathogens.

\section{ACKNOWLEDGMENTS}

The study was supported by the EFOP-3.6.1-16-2016-00008 European Union-Hungary grant.

We declare that we have no competing interests. 


\section{REFERENCES}

1. Bošnjak $Z$, Džijan $S$, Pavlinić $D$, Perić $M$, Ružman $N$, Križan IR, Lauc $G$, Antolović-Požgain A, Burazin J, Vuković D. 2012. Distribution of Chlamydia trachomatis serotypes in clinical urogenital samples from northeastern Croatia. Curr Microbiol 64:552-560. https://doi.org/10.1007/ s00284-012-0106-7.

2. Wikström E, Surcel H-M, Merikukka M, Ohman H, Namujju PB, Tasanen $K$, Tiitinen A, Paavonen J, Lehtinen M. 2014. Changes over time in the Chlamydia trachomatis serotype distribution in Finnish women. Scand J Infect Dis 46:397-400. https://doi.org/10.3109/00365548.2013.878031.

3. Gao X, Chen X-S, Yin Y-P, Zhong M-Y, Shi M-Q, Wei W-H, Chen Q, Peeling RW, Mabey D. 2007. Distribution study of Chlamydia trachomatis serovars among high-risk women in China performed using PCR-restriction fragment length polymorphism genotyping. J Clin Microbiol 45: 1185-1189. https://doi.org/10.3109/00365548.2013.878031.

4. Centers for Disease Control and Prevention. 2016. Sexually transmitted diseases surveillance. Centers for Disease Control and Prevention, Atlanta, GA.

5. Aiyar A, Quayle AJ, Buckner LR, Sherchand SP, Chang TL, Zea AH, Martin $\mathrm{DH}$, Belland RJ. 2014. Influence of the tryptophan-indole-IFN $\gamma$ axis on human genital Chlamydia trachomatis infection: role of vaginal coinfections. Front Cell Infect Microbiol 4:72. https://doi.org/10.3389/fcimb .2014.00072

6. Lai BE, Geonnotti AR, Desoto MG, Montefiori DC, Katz DF. 2010. Semisolid gels function as physical barriers to human immunodeficiency virus transport in vitro. Antiviral Res 88:143-151. https://doi.org/10.1016/j .antiviral.2010.08.006.

7. Mahalingam A, Simmons AP, Ugaonkar SR, Watson KM, Dezzutti CS, Rohan LC, Buckheit RW, Kiser PF. 2011. Vaginal microbicide gel for delivery of IQP-0528, a pyrimidinedione analog with a dual mechanism of action against HIV-1. Antimicrob Agents Chemother 55:1650-1660. https://doi.org/10.1128/AAC.01368-10.

8. Eder T, Kobus S, Stallmann S, Stepanow S, Köhrer K, Hegemann JH, Rattei T. 2017. Genome sequencing of Chlamydia trachomatis serovars $E$ and $F$ reveals substantial genetic variation. Pathog Dis 75. https://doi.org/10 .1093/femspd/ftx120.

9. EDQM Council of Europe. 2017. European Pharmacopoeia (Ph. Eur.), 9th ed. EDQM, Strasbourg, France.

10. Owen DH, Katz DF. 1999. A vaginal fluid simulant. Contraception 59: 91-95. https://doi.org/10.1016/S0010-7824(99)00010-4.

11. Eszik I, Lantos I, Önder K, Somogyvári F, Burián K, Endrész V, Virok DP. 2016. High dynamic range detection of Chlamydia trachomatis growth by direct quantitative PCR of the infected cells. J Microbiol Methods 120:15-22. https://doi.org/10.1016/j.mimet.2015.11.010.

12. Bogdanov A, Endrész V, Urbán S, Lantos I, Deák J, Burián K, Önder K, Ayaydin F, Balázs P, Virok DP. 2014. Application of DNA chip scanning technology for automatic detection of Chlamydia trachomatis and Chlamydia pneumoniae inclusions. Antimicrob Agents Chemother 58: 405-413. https://doi.org/10.1128/AAC.01400-13.

13. Sater AAA, Ojcius DM, Meyer MP. 2008. Susceptibility of Chlamydia trachomatis to the excipient hydroxyethyl cellulose: $\mathrm{pH}$ and concentration dependence of antimicrobial activity. Antimicrob Agents Chemother 52:2660-2662. https://doi.org/10.1128/AAC.00785-07.

14. Gao Y, Yuan A, Chuchuen O, Ham A, Yang KH, Katz DF. 2015. Vaginal deployment and tenofovir delivery by microbicide gels. Drug Deliv Transl Res 5:279-294. https://doi.org/10.1007/s13346-015-0227-1.

15. Thomson NR, Holden MTG, Carder C, Lennard N, Lockey SJ, Marsh P, Skipp P, O'Connor CD, Goodhead I, Norbertzcak H, Harris B, Ormond D, Rance R, Quail MA, Parkhill J, Stephens RS, Clarke IN. 2008. Chlamydia trachomatis: genome sequence analysis of lymphogranuloma venereum isolates. Genome Res 18:161-171. https://doi.org/10.1101/gr.7020108.

16. Davis CH, Wyrick PB. 1997. Differences in the association of Chlamydia trachomatis serovar E and serovar L2 with epithelial cells in vitro may reflect biological differences in vivo. Infect Immun 65:2914-2924.

17. Kuo CC, Grayston T. 1976. Interaction of Chlamydia trachomatis organisms and HeLa 229 cells. Infect Immun 13:1103-1109.

18. Hegemann JH, Moelleken K. 2012. Chlamydial adhesion and adhesins. In Intracellular pathogens I: chlamydiales. ASM Press, Washington, DC. 


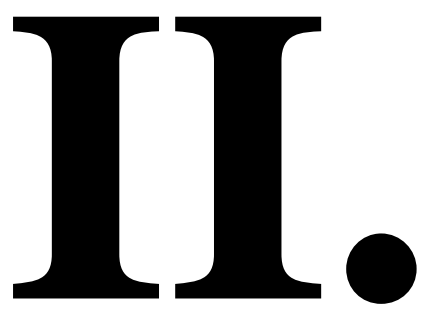




\section{OPEN ACCESS}

Edited by:

Thomas Rudel,

University of Wuerzburg, Germany

Reviewed by:

Thuy Do,

University of Leeds, United Kingdom Andreas Klos,

Hannover Medical School, Germany

${ }^{*}$ Correspondence:

Dezső P. Virok

virok.dezso.peter@med.u-szeged.hu

Specialty section:

This article was submitted to

Bacteria and Host,

a section of the journal

Frontiers in Cellular and Infection

Microbiology

Received: 28 February 2019 Accepted: 20 May 2019

Published: 12 June 2019

Citation:

Virok DP, Raffai T, Kókai D, Paróczai D,

Bogdanov A, Veres $G$, Vécsei L,

Poliska S, Tiszlavicz L, Somogyvári F,

Endrész V and Burián K (2019)

Indoleamine 2,3-Dioxygenase Activity

in Chlamydia muridarum and

Chlamydia pneumoniae Infected

Mouse Lung Tissues.

Front. Cell. Infect. Microbiol. 9:192.

doi: 10.3389/fcimb.2019.00192
Indoleamine 2,3-Dioxygenase Activity in Chlamydia muridarum and Chlamydia pneumoniae Infected Mouse Lung Tissues

\author{
Dezsö P. Virok ${ }^{1 *}$, Tímea Raffai ${ }^{1}$, Dávid Kókai ${ }^{1}$, Dóra Paróczai ${ }^{1}$, Anita Bogdanov ${ }^{1}$, \\ Gábor Veres ${ }^{2,3}$, László Vécsei ${ }^{2,3}$, Szilárd Poliska ${ }^{4}$, László Tiszlavicz ${ }^{5}$, Ferenc Somogyvári ${ }^{1}$, \\ Valéria Endrész ${ }^{1}$ and Katalin Burián ${ }^{1}$ \\ ${ }^{1}$ Department of Medical Microbiology and Immunobiology, Faculty of Medicine, University of Szeged, Szeged, Hungary, \\ ${ }^{2}$ MTA-SZTE Neuroscience Research Group, Szeged, Hungary, ${ }^{3}$ Department of Neurology, Faculty of Medicine, Albert \\ Szent-Györgyi Clinical Center, University of Szeged, Szeged, Hungary, ${ }^{4}$ Genomic Medicine and Bioinformatics Core Facility, \\ Department of Biochemistry and Molecular Biology, Faculty of Medicine, University of Debrecen, Debrecen, Hungary, \\ ${ }^{5}$ Department of Pathology, Faculty of Medicine, Albert Szent-Györgyi Clinical Center, University of Szeged, Szeged, Hungary
}

Chlamydia trachomatis infections are the most prevalent sexually transmitted infections with potentially debilitating sequelae, such as infertility. Mouse models are generally used for vaccine development, to study the immune response and histopathology associated with Chlamydia infection. An important question regarding murine models is the in vivo identification of murine host genes responsible for the elimination of the murine and human Chlamydia strains. RNA sequencing of the Chlamydia muridarum infected BALB/c lung transcriptome revealed that several genes with direct antichlamydial functions were induced at the tissue level, including the already described and novel members of the murine interferon-inducible GTPase family, the CXCL chemokines CXCL9, CXCL11, immunoresponsive gene 1, nitric oxide synthase-2 (iNOS), and lipocalin-2. Indoleamine 2,3-dioxygenase 1-2 (IDO1-2) previously described potent antichlamydial host enzymes were also highly expressed in the infected murine lungs. This finding was novel, since IDO was considered as a unique human antichlamydial defense gene. Besides a lower level of epithelial cell positivity, immunohistochemistry showed that IDO1-2 proteins were expressed prominently in macrophages. Detection of the tryptophan degradation product kynurenine and the impact of IDO inhibition on Chlamydia muridarum growth proved that the IDO1-2 proteins were functionally active. IDO1-2 activity also increased in Chlamydia muridarum infected C57BL/6 lung tissues, indicating that this phenomenon is not mouse strain specific. Our study shows that the murine antichlamydial response includes a variety of highly up-regulated defense genes in vivo. Among these genes the antichlamydial effectors IDO1-2 were identified. The potential impact of murine IDO1-2 expression on Chlamydia propagation needs further investigation.

Keywords: IDO, iNOS, nitric oxide, Chlamydia, mouse, lung, interferon, interferon-inducible GTPases 


\section{INTRODUCTION}

Chlamydiae are obligate intracellular bacteria that propagate prominently in the epithelial cells of the respiratory and urogenital tract. The socioeconomic impact of C. trachomatis infection is significant. In developing countries, the ocular serovars of the species cause trachoma, the chronic infection/inflammation of the conjunctiva. Trachoma is the most important cause of preventable, infection-related blindness and in 2008 about 40 million people had active trachoma infection (Mariotti et al., 2009). Urogenital serotypes of Chlamydia trachomatis (C. trachomatis) are the most prevalent bacteria related to sexually transmitted infections (Centers for Disease Control Prevention, 2014), frequently leading to chronic infections with debilitating sequelae such as ectopic pregnancy and infertility. C. trachomatis infections can be treated effectively with macrolides and doxycycline (Kong et al., 2014), but the symptoms of urogenital infections are frequently mild and therefore the infection may be left untreated (Lallemand et al., 2016). Though the prevention of the infection with vaccination would be important, an effective vaccine has not yet been developed. Mouse models are the most frequently used ones for vaccine development, but the differences between the human and murine immune systems, including the so-called cell-autonomous immunity makes the mouse models difficult to compare with humans (Finethy and Coers, 2016). Cell autonomous immunity is an intrinsic feature of the host cells, which launches defense mechanisms that interfere with the growth of intracellular pathogens. Typically these defense genes are inducible, and interferon-gamma (IFNG) is a prominent inducer cytokine. It has been described previously that the major intracellular antichlamydial defense mechanism in human cells is the IFNG-induced IDO expression, which leads to the degradation of the intracellular tryptophan pool and eventually the death of the tryptophan-auxotroph C. trachomatis (Byrne et al., 1986). This elimination mechanism is effective in vitro for both the human C. trachomatis and the genetically closely related murine Chlamydia species C. muridarum (Roshick et al., 2006). Nevertheless in vitro data showed that IDO is not inducible by Chlamydia infection and/or IFNG in mouse epithelial cells (Roshick et al., 2006). Instead, microarray analysis of IFNG treated and Chlamydia infected murine epithelial cells revealed that the IFN-inducible GTPases are the suspected host genes that interfere with the developmental cycle of human Chlamydia strains (Nelson et al., 2005). Murine Chlamydia strain developed mechanism(s) to inactivate the GTPase response and render this elimination mechanism ineffective (Nelson et al., 2005; Coers et al., 2008). Despite this, the C. muridarum strain is rapidly eliminated from the murine cervicovaginal tract (Nelson et al., 2005), hence yet unknown elimination mechanisms exist in mice that are effective against the murine Chlamydia strain in vivo.

The aim of our experiments was to find murine defense genes that could be involved in the elimination of the murine Chlamydia strain. We chose a murine lung infection model, where the complexity of the in vivo environment-including the impact of a variety of cytokines and cell-cell interactionscould induce the expression of a diverse set of host genes. We performed an unbiased study, where we explored the inducible murine genes by screening the global gene expressions of the $C$. muridarum infected murine lungs.

\section{METHODS}

\section{Propagation of Chlamydia pneumoniae and C. muridarum}

Chlamydia pneumoniae (C. pneumoniae) CWL029 strain from American Type Culture Collection (ATCC, Manassas, VA, USA) was propagated in HEp-2 cells (ATCC), as described earlier (Burián et al., 2003). C. muridarum strain Nigg (Nelson et al., 2005) was grown in McCoy cells (ECACC, London, UK). After partial purification and concentration the elementary bodies (EBs) were aliquoted in sucrose-phosphate-glutamic acid buffer (SPG) and stored at $-80^{\circ} \mathrm{C}$ until use (Caldwell et al., 1981).

\section{Mice and Infection Conditions}

Pathogen-free 6-week-old female BALB/c mice were obtained from the Charles River Laboratories (Hungary), C57BL/6 mice were obtained from BRC Animal House (Szeged, Hungary). The mice were maintained under standard husbandry conditions at the animal facility of the Department of Medical Microbiology and Immunobiology, University of Szeged, and were provided with food and water ad libitum. Before infection, the mice were mildly sedated with an intraperitoneal injection of $200 \mu \mathrm{l}$ of sodium pentobarbital $(7.5 \mathrm{mg} / \mathrm{ml})$; they were then infected intranasally with $4 \times 10^{5}$ IFU C. pneumoniae $(\mathrm{BALB} / \mathrm{c})$ or 1 $\times 10^{3}$ IFU of $C$. muridarum (BALB/c and C57BL/6) in 20 $\mu l$ SPG buffer. Control mice were treated with $20 \mu \mathrm{l}$ SPG buffer only. The mice were anesthetized and sacrificed 7 days after infection. The lungs were removed and homogenized with acid-purified sea sand (Sigma, St. Louis, MO, USA). Half of each homogenized lung was processed for total RNA extraction, and the other half was suspended in $1 \mathrm{ml}$ of SPG for the detection of viable Chlamydia and to test the quantity of kynurenine and tryptophan. The lungs of three mice from both groups were fixed in $10 \%$ neutral buffered formalin solution (Sigma) for histopathological evaluation. The experiments were approved by the Animal Welfare Committee of the University of Szeged and conform to the Directive 2010/63/EU of the European Parliament.

\section{Culturing of Chlamydia From Mouse Lungs}

Homogenized lungs from individual mice were centrifuged $(10 \mathrm{~min}, 400 \mathrm{~g})$, serial dilutions of the supernatants were inoculated onto McCoy cell monolayers and centrifuged ( $1 \mathrm{~h}$, $800 \mathrm{~g}$ ), and after a 48 -h culture the cells were fixed with acetone and stained with monoclonal anti-Chlamydia LPS antibody (AbD Serotec, Oxford, UK) and FITC-labeled antimouse IgG (Sigma). The number of the recoverable Chlamydia inclusions was counted under a UV microscope and expressed as IFU/lung.

\section{In vivo IDO Inhibition by 1-Methyl-DL-Tryptophan}

Seven days before infection with $C$. muridarum the drinking water of 8 weeks old female BALB/c mice $(n=4)$ was changed to that containing $2 \mathrm{mg} / \mathrm{ml}$ IDO inhibitor 1-methyl-DL-tryptophan 
(1-MT; Sigma), dissolved in $10 \mathrm{mmol} / \mathrm{l} \mathrm{NaOH}$ supplemented with Stevia sweetener. Control mice $(n=4)$ received the Steviasweetened drinking water with $10 \mathrm{mmol} / \mathrm{l} \mathrm{NaOH}$ without 1 MT. The solution was delivered in autoclaved water bottles, protected from light, and changed every other day. The infection of mice and the estimation of recoverable viable C. muridarum from the lungs at 7 days post infection were carried out as described previously.

\section{Total RNA Extraction and cDNA Synthesis}

Total RNA was extracted from homogenized lung tissues of $C$. muridarum infected BALB/c $(n=3)$ and C57BL/6 mice $(n=$ 5), C. pneumoniae infected BALB/c mice and uninfected controls with Tri Reagent according to the manufacturer's protocol (Sigma). Total RNA quantity (OD260) and purity (OD260/280) were measured by a NanoDrop spectrophotometer (Thermo Scientific, Waltham, MA, USA).

\section{cDNA Library Preparation and Sequencing}

cDNA library for RNA-Seq was generated from $1 \mu \mathrm{g}$ total BALB/c lung RNA using TruSeq RNA Sample Preparation Kit (Illumina, San Diego, CA, USA) according to the manufacturer's protocol. Single read $50 \mathrm{bp}$ sequencing run was performed on Illumina HiScan SQ instrument (Illumina). CASAVA software was used for pass filtering and demultiplexing process. Sequenced reads were aligned to Mus musculus mm10 genome version using TopHat and Cufflinks algorithms and bam files were generated.

\section{Statistical and Functional Analysis of RNA-Sequencing Data}

StrandNGS software (Agilent, Santa Clara, CA, USA) was used for the statistical analysis of RNA-sequencing (RNA-Seq) data. The aligned bam files were imported and DESeq algorithm was used in the quantification step to generate normalized gene expression data. Differentially expressed genes between C. muridarum infected lung samples $(n=3)$ and controls $(n=3)$ were determined using the Student's $t$-test combined with Benjamini-Hochberg FDR for multiple testing correction. Statistical significance was defined as $P_{\text {Benjamini-Hochberg }}<$ 0.05 . Library preparations, sequencing and data analysis were performed by UD-GenoMed Kft. and the Genomic Medicine and Bioinformatics Core Facility of University of Debrecen, Debrecen, Hungary. Large scale functional analysis of differentially expressed genes were performed by the Voronto software (Santamaría and Pierre, 2012). The Voronto method identifies the Gene Ontology terms and KEGG pathways that contain significantly enriched differentially expressed genes. Voronto software uses the so-called Voronoi tessellation to map ontology terms or pathways into a map-like structure. The cells of the map are the ontology terms, the closer terms being located closer to each other. Terms with a common ancestor are surrounded by a thicker line.

\section{Quantitative PCR Validation of the ID01 and IDO2 RNA-Seq Data}

For quantitative PCR (qPCR) $1 \mu \mathrm{g}$ of total RNA was reverse transcribed using the Maxima Reverse Transcriptase according to the manufacturer's protocol with random hexamer priming (Thermo Fisher Scientific Inc. Waltham, MA, USA). qPCR was performed in a Bio-Rad CFX96 real-time system. The qPCR was performed with the SsoFast EvaGreen qPCR Supermix (Bio-Rad, Hercules, CA, USA) master mix and the murine specific primer pairs IDO1: 5'-GCTTCTTCCTCGTCTCTCT ATTG-3', 5'-TCTCCAGACTGGTAGCTATGT-3'; IDO2: $5^{\prime}$ CCTGGACTGCAGATTCCTAAAG-3', 5'-CCAAGTTCCTGG ATACCTCAAC-3'; beta-actin: 5'-TGGAATCCTGTGGCATCC ATGAAAC-3', 5' -TAAAACGCAGCTCAGTAACAGTCCG-3'. To check the amplification specificity, the qPCR was followed by a melting curve analysis. Threshold cycles (Ct) were calculated for IDO1, IDO2 and beta-actin genes, and the normalized gene expressions were calculated by the $\Delta \mathrm{Ct}$ method $\left(\mathrm{Ct}_{\mathrm{IDO} 1}-\mathrm{Ct}_{\mathrm{actin}}\right.$ or $\left.\mathrm{Ct}_{\mathrm{IDO} 2}-\mathrm{Ct}_{\mathrm{actin}}\right)$. Statistical comparison of $\mathrm{qPCR}$ data was performed by comparing the $\Delta \mathrm{Ct}$ values of uninfected and infected lung samples $(n=3)$ by using the Student's $t$-test as described earlier (Yuan et al., 2006).

\section{IDO1 and IDO2 Immunohistochemistry of Chlamydia Infected and Uninfected Mouse Lungs}

IDO1 and IDO2 immunohistochemistry was performed on the $\mathrm{BALB} / \mathrm{c}$ lungs that were used in the gene expression studies. Macroscopically inflamed lung sections and control lungs were cut and fixed in $10 \%$ formalin (Sigma). Fixed samples were cut into $4 \mu \mathrm{m}$ sections. Tissue sections were first deparaffinized, followed by antigen retrieval and inhibition of endogen peroxidases using the EnVision FLEX Peroxidase-blocking reagent (Dako, Carpinteria, CA, USA). IDO immunohistochemistry was performed with a goat polyclonal anti-IDO1 antibody (Sigma) and a rabbit polyclonal anti-IDO2 antibody (Bioss, Woburn, MA, USA) followed by HRP-conjugated anti-goat rabbit (Dako) and anti-rabbit goat secondary antibodies (Dako), respectively.

\section{Detection of Tryptophan and Kynurenine Concentrations in Lung Tissues}

Infected and control $\mathrm{BALB} / \mathrm{c}$ and $\mathrm{C} 57 \mathrm{BL} / 6$ mouse lung tissues were homogenized with sterile sand (Sigma), and dissolved in $700 \mu \mathrm{l} 1 \times \mathrm{PBS}$. The samples were sonicated $2 \times 1 \mathrm{~min}$, vortexed and centrifuged at $500 \mathrm{~g}$ for $5 \mathrm{~min}$. Twenty microliters of internal standard (3-nitro L-tyrosine (3NLT, Sigma), $2 \mu \mathrm{M}$ final concentration in the sample) in $2.5 \mathrm{w} / \mathrm{w} \%$ perchloric acid was added to $480 \mu \mathrm{l}$ supernatant and mixed with $500 \mu \mathrm{l}$ perchloric acid $(2.5 \mathrm{w} / \mathrm{w} \%)$. The samples were subsequently centrifuged at $12,000 \mathrm{~g}$ for $10 \mathrm{~min}$ at $4^{\circ} \mathrm{C}$, and the supernatants were collected for measurement. The tryptophan and kynurenine concentrations of the samples were quantified based on the work of Hervé et al. (1996) with slight modifications (Veres et al., 2015). In the high-performance liquid chromatography (HPLC) analysis, the peak area responses were plotted against the corresponding concentration, and the linear regression computations were carried out using the least squares method with the R software package (R Core Team, 2014). 


\section{RESULTS}

\section{Chlamydia Infection and Chlamydia-Induced Histopathology}

In our animal model different doses of the two Chlamydia strains were used $\left(4 \times 10^{5}\right.$ IFU of $C$. pneumoniae and $1 \times$ $10^{3}$ IFU of C. muridarum), based on the results of our former experiments (Burián et al., 2003; Kis et al., 2008) where the lower dose of the murine pathogen $C$. muridarum induced similar growth and histopathology than the human pathogen $C$. pneumoniae. Indeed, recoverable IFUs from the C. muridarum and C. pneumoniae infected BALB/c lungs were similar at 7 days post infection (Figure 1A). Both infections induced a lymphoid hyperplasia, with the interstitial accumulation of lymphoid, plasmocytoid cells, and macrophages in the widened bronchus walls. The histology picture was consistent with the formation of inducible bronchus associated lymphatic tissue (iBALT). At this time of the infection, the presence of neutrophils were marginal, the major leukocyte populations were lymphocytes and macrophages (Figures 1B,C). Control lung tissue showed thin alveolar septa without the clear presence of inflammatory cells, but a small number of pulmonary macrophages could be detected (Figure 1D).

\section{Global Gene Expression Changes in the C. muridarum Infected Mouse Lung Tissues}

To explore the global gene expression changes induced at the tissue level by the murine Chlamydia strain we performed an Illumina next generation RNA sequencing of $\mathrm{BALB} / \mathrm{c}$ mouse lung tissues infected with $C$. muridarum 7 days post infection. RNA-seq analysis revealed that 755 murine genes had a higher expression and 251 genes had a lower expression than the uninfected control. The extent of up-regulation and the number of up-regulated genes was higher (1.48-345 fold), than in the case of the down-regulated genes (1.5-14.36 fold). The most highly up-regulated gene was the CXCL11 (I-TAC), and several cytokines/ chemokines were among the highly upregulated genes including CXCL9 (MIG), CXCL10 (IP-10), CCL8 (MCP2), CCL2 (MCP1), IFNG, IL21, IL10, as well as already described defense genes IRG1, IIGP and IDO1. The most highly down-regulated gene was cDNA sequence $B C 023719$ with a 14.36 fold of downregulation, and the functions of the most highly down-regulated genes were diverse. The list of differentially expressed genes can be found in the Supplementary Table 1.

Functional analysis of the differentially expressed genes using the Voronto method revealed several KEGG pathways that are related to Chlamydia-induced inflammation and antichlamydial innate and adaptive defense responses (Figure 2A). Several upregulated genes rendered to cell-type specific KEGG pathways such as T-cell, B-cell, NK-cell and hematopoietic cells-specific pathways indicating the influx of these leukocytes into the infected lung tissues. Indeed, increased expressions of various cell-specific genes and $\mathrm{CD}$ markers were detected such as T-cell markers CD3, CD4, CD5, CD6, CD7, CD226, B cells markers CD5, CD7, dendritic cell marker CD4, NK-cell markers
CD4, CD7, natural killer cell lectin-like receptors (KLRA2, KLRB1F, KLRK1, KLRI2, KLRC2, KLRD1) and macrophagespecific genes CD4, MSR1, and MPEG1, indicating the influx and/or local proliferation of these cells in the infected lung tissue. Interestingly, when the up-regulated genes were compared to the Mouse Gene Atlas gene expression database (Kuleshov et al., 2016), the most significant overlap was detected with the LPS treated macrophage gene expression (data not shown), indicating the active involvement of activated macrophages in the Chlamydia-induced gene expression changes. We detected several highly upregulated chemokines, that could induce the cellular influx, including the lymphocyte chemokines CCL2 (MCP1), CCL5 (RANTES), CCL8 (MCP2), CXCL9 (MIG), CXCL10 (IP10), CXCL11 (I-TAC), the monocyte chemokines CCL2, CCL4 (MIP1B), CCL7 (MCP3), CCL8 (MCP2), CXCL10 and the neutrophil granulocyte chemokine CXCL5 (ENA78). Enhancing the effects of chemokines, various chemokine receptors were also up-regulated including the MCP1 receptor CCR2, the MCP1-MIP1-RANTES receptor CCR4, the MIP1B receptor CCR5 and the MIG-IP10-I-TAC receptor CXCR3.

Gene Ontology molecular function analysis supported the KEGG pathway analysis (Figure 2B). The fact that various "cell cycle" pathway related genes were found to be up-regulated indicates the accelerated division of activated cells including the induction of BALT. The cellular activation is induced by ligandreceptor interactions in both adaptive and innate immunity. Indeed, among the largest functional groups identified were "cytokine activity," "transmembrane signaling" and "protein kinase activity" containing prominently up-regulated and highly up-regulated cytokines, cytokine receptors and downstream signaling genes. Several adaptive immunity related genes, mainly MHC-I antigen presentation related genes were up-regulated. The pathogen recognition/proinflammation pathways such as the toll-like receptor (TLR1, TLR6, TLR7, TLR12), cytosolic DNA sensing, NOD-like, RIG-I-like pathways contained up-regulated genes showing that the extra and intracellular forms of the pathogen could be recognized and could induce an inflammatory response. Among the cytokine signaling pathways, IFN-related signaling pathways and IFN-induced gene expressions were particularly noticeable, including up-regulated genes IFNG, STAT1, STAT2, IRF7, IRF9, and IFN-induced genes such as several histocompatibility complex genes, IFN-inducible GTPases and tryptophan catabolism genes IDO1 and KYNU.

\section{Antimicrobial Genes Induced by C. muridarum Infection}

A prominent identified Gene Ontology molecular functional category was "GTP binding." Most of the GTPases in this category are involved in defense responses against intracellular pathogens (Figure 2B). Essentially all four classes of murine IFN-inducible GTPases were found to be up-regulated including various guanylate-binding proteins (GBP2-9, GBP11), the myxovirus resistance protein-1 (MX1), immunity-related GTPases IRGM1 (LRG47), IRGM2 (GTPI), IRGA6 (IIGP), IRGM3 (IGTP), IRGB6 (TGTP1-2), IRGB10 (Gm12250), and a very large IFN-inducible GTPase GVIN1. It is worth to note, 

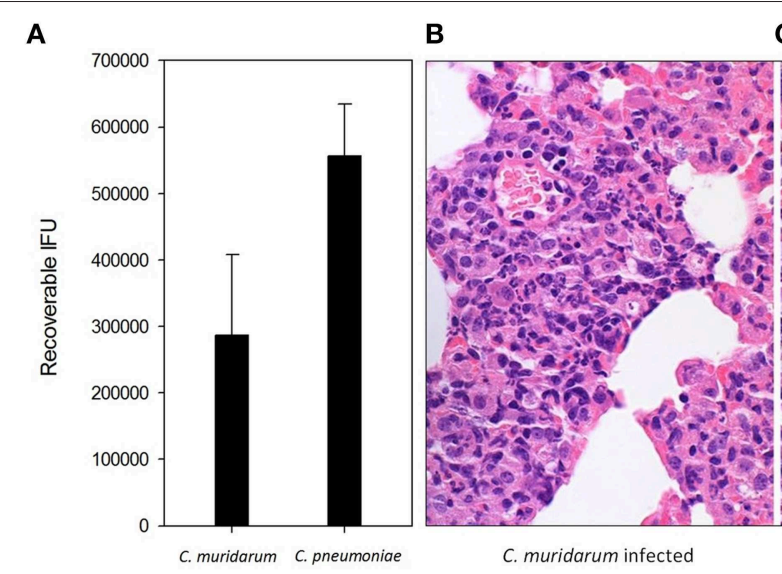

C

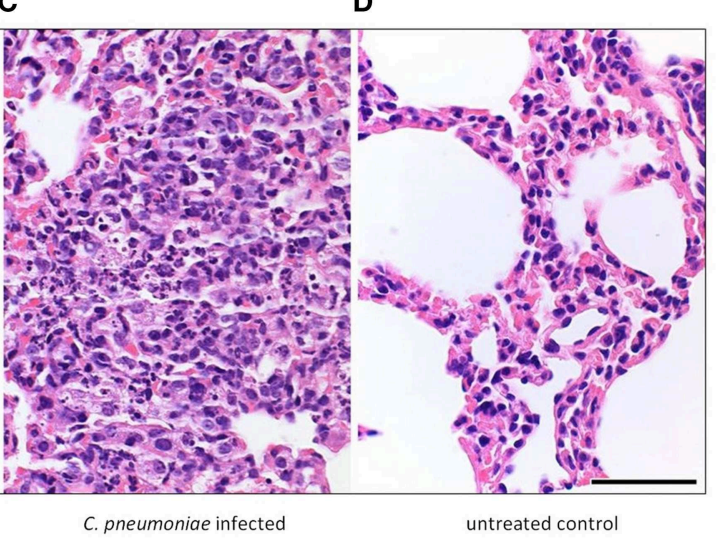

FIGURE 1 | Chlamydia infection and Chlamydia-induced histopathology in BALB/c mouse lung tissues. Recoverable IFUs from C. muridarum infected and C. pneumoniae infected mouse lungs at 7 days post infection (A). Haematoxylin-eosin staining of C. muridarum infected (B), C. pneumoniae infected (C) and uninfected (D) lung tissues. Bar is $50 \mu \mathrm{m}$.

that three predicted genes with a sequence homology to IIGP (Gm4841, Gm4951, F830016B08Rik) and three with a sequence homology to TGTP (Gm12185, Gm5431, 9930111J21Rik1) were found to be up-regulated or highly up-regulated in the infected lungs (Figure 2B). Interestingly, Gm12185, Gm5431, and 9930111J21Rik are localized on chromosome 11, close to the region where potential defense genes against $C$. trachomatis were found by QTL mapping (Bernstein-Hanley et al., 2006a,b). Besides the IFN-inducible GTPases genes, other genes such as CXCL9, iNOS, and IDO1 with known antichlamydial activity against human and murine Chlamydia strains were highly up-regulated (127 fold, 14 fold, and 24.7 fold, respectively). Additional genes with known antimicrobial activity, but unknown antichlamydial activity were found to be up-regulated including CXCL11 (345 fold), IRG1 (252.7 fold), lipocalin-2 (11 fold), mucin-5 (8.7 fold) and solute carrier family 11 (5.5 fold).

\section{qPCR Validation of IDO1 and IDO2 RNA-Seq Data}

The fact that the IDO1 gene was highly upregulated (24.76 fold) in the infected lungs was an unexpected finding since the IDO1 was found to be non-inducible by $C$. trachomatis or $C$. muridarum infection in vitro in murine epithelial and other cells (Nelson et al., 2005; Roshick et al., 2006; Burian et al., 2010). IDO1 was detected as a significantly changed gene ( $P$ $=0.037$ ) between the $C$. muridarum infected and uninfected samples, while the IDO2 was detected non-significant. However, as Figures 3A,B shows, both IDO1 and IDO2 genes had more sequence reads in the infected samples than the uninfected ones. Yet, in the case of $I D O 2$, the read numbers were not high enough to be detected as a significantly changed gene. We used qPCR as an independent method to validate RNASeq data for IDO1 and IDO2. Also, in order to test whether the IDO1-2 induction is unique to the murine Chlamydia strain, we measured the IDO1-2 gene expressions in C. pneumoniae infected lung samples. qPCR data supported the RNA-Seq data in the case of C. muridarum infection with a $20.38 \pm$ 11.3 fold and $38.2 \pm 25.2$ fold of upregulation of IDO1 and IDO2, respectively. qPCR also showed a similar extent of upregulation $15.5 \pm 14.1$ fold and $88.9 \pm 73.9$ fold for $I D O 1$ and $\mathrm{IDO} 2$, respectively in the C. pneumoniae infected lung tissues (Figure 3C).

\section{ID01-2 Protein Expression in C. muridarum and C. pneumoniae BALB/c Infected Mouse Lung Tissues}

To prove that the observed IDO1 and IDO2 mRNA changes translated to protein expression changes, and to localize the cell type(s) that express these proteins, we performed an immunohistochemistry of C. muridarum and C. pneumoniae infected lung sections and uninfected controls. Moderate IDO12 positivity could be detected in the cytoplasm of bronchial and occasionally alveolar epithelial cells and moderate/strong positivity was detected frequently in macrophages in the $C$. pneumoniae and C. muridarum infected mouse lung tissues (Figure 4). C. pneumoniae and C. muridarum infections lead to similar IDO1-2 positivity in these cells. The control, uninfected lung tissues also contained IDO1-2 positive bronchial epithelial cells, and a small number of IDO1-2 positive macrophages.

\section{IDO 1-2 Activity in C. muridarum and $C$. pneumoniae Infected BALB/c Mouse Lung Tissues}

To determine whether the expressed IDO1 and IDO2 proteins were functional, we performed a HPLC analysis of the infected and control lung tissues of mice included in the gene expression and immunohistochemistry measurements. We measured IDO1-2 activity by measuring the total tryptophan level, and the level of the tryptophan degradation metabolite kynurenine. The applied HPLC method could not detect kynurenine in the uninfected lungs, while the C. muridarum 


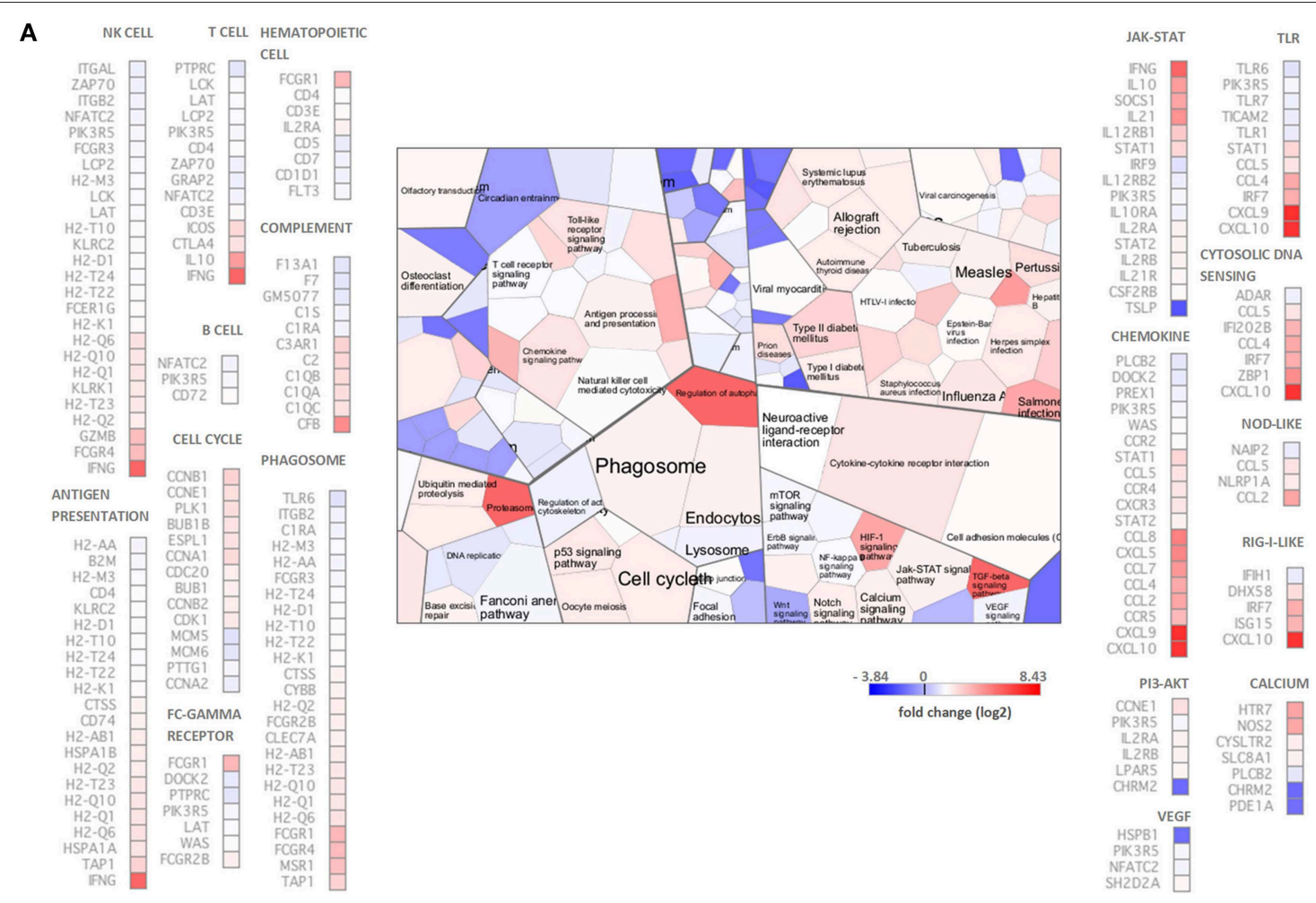

B

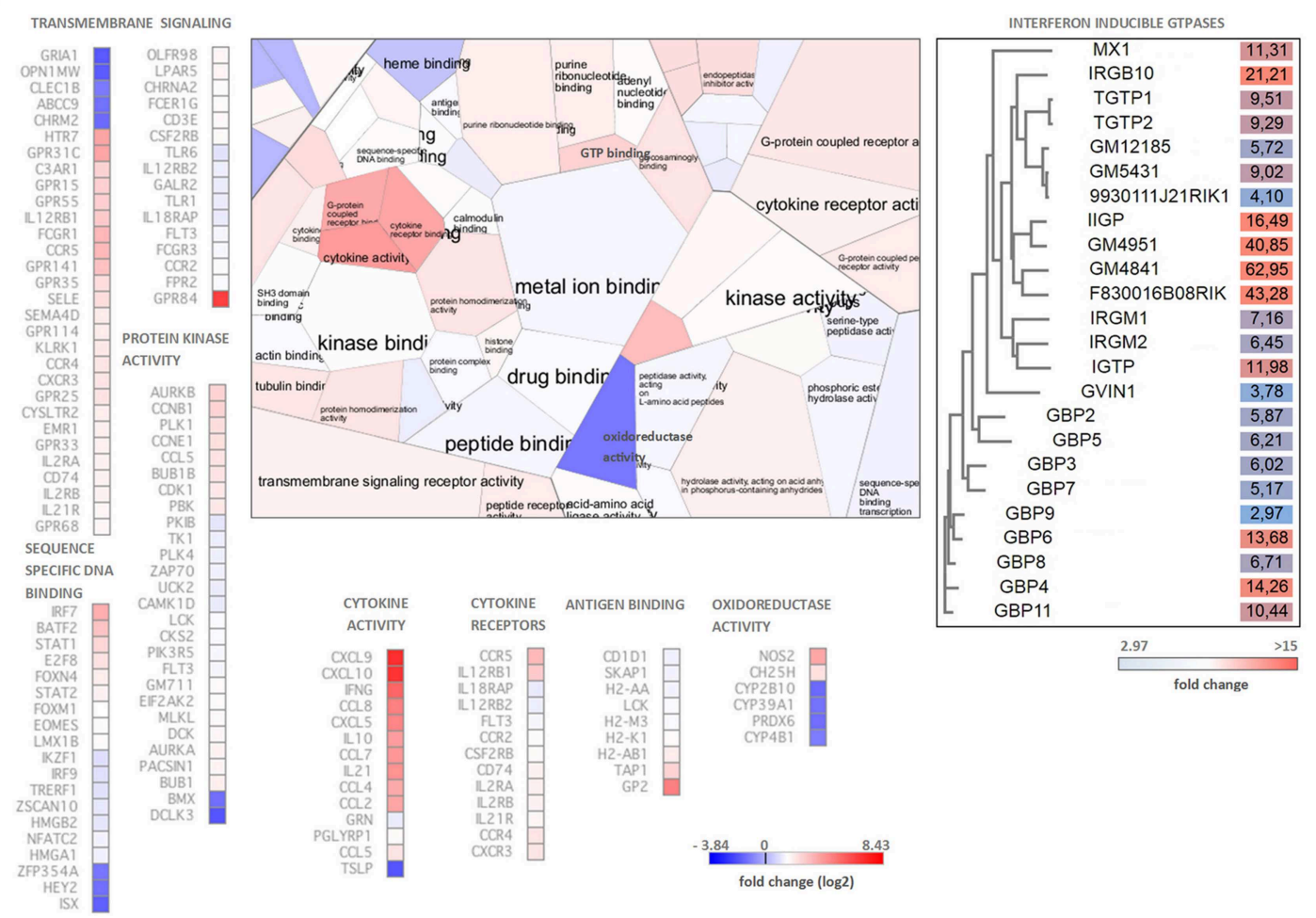

FIGURE 2 | Functional analysis of the C. muridarum infection altered genes by the Voronto method. (A) Analysis of significantly enriched KEGG pathways containing differentially expressed genes. (B) Gene Ontology analysis of significantly enriched molecular function terms containing differentially expressed genes. The differentially expressed IFN-inducible GTPases are grouped based on their amino acid sequences shown separately with their fold of up-regulation. Chlamydia induced inflammation, immunity and antichlamydial defense related Gene Ontology terms and KEGG pathways and the corresponding genes are shown separately. Cell colors of the Voronto diagrams show the mean fold change $(\log 2)$ of the differentially expressed genes related to the particular Voronto cells. Both for the Voronto cells and the genes, the log2 fold changes are color coded according to the scales. Note that the colors of the up-regulated genes ranging from light blue to red, while the down-regulated genes are dark blue. 
A

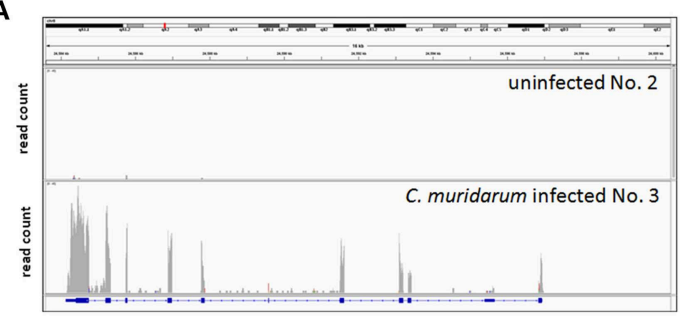

B

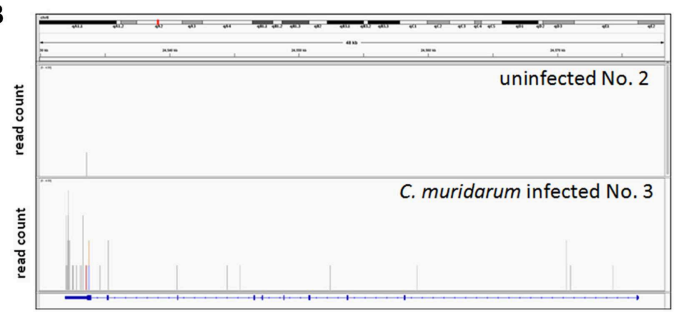

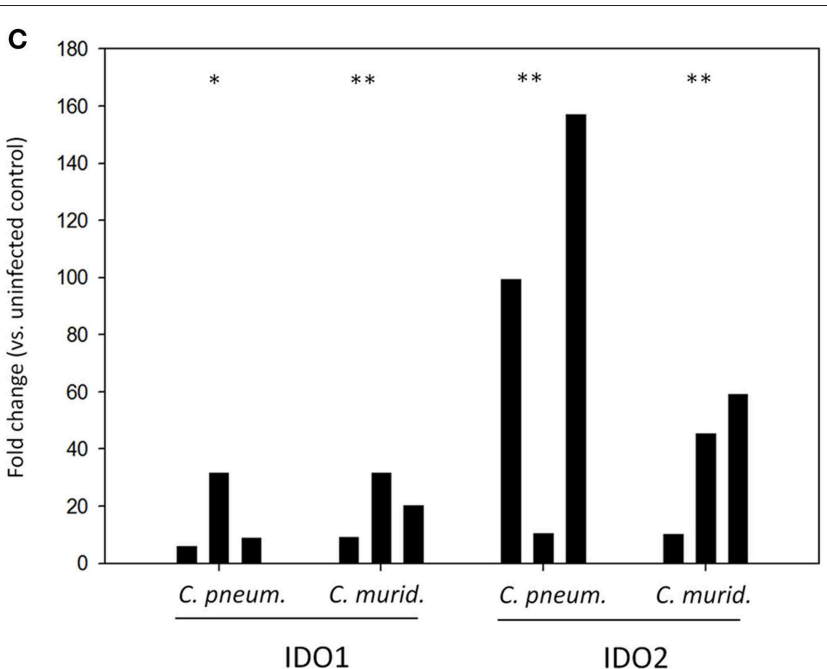

IDO1
IDO2

FIGURE 3 | IDO1 and IDO2 mRNA expression measurements by RNA-Seq and qPCR. Integrative Genomics Viewer (Thorvaldsdóttir et al., 2013) images showing the coverage of IDO1 (A) and IDO2 (B) genes by sequencing reads in a representative C. muridarum infected and uninfected control samples. IDO1 and IDO2 gene expression inductions measured by qPCR in C. muridarum and C. pneumoniae infected lung tissues $(n=3)(\mathbf{C})$. IDO1 and IDO2 gene expression fold changes in each infected mice $(n=3)$ were calculated by comparing the average IDO1 and IDO2 expressions in the uninfected controls ( $n=3$ ). IDO1 and IDO2 gene expressions were normalized by the beta-actin gene expressions. $\Delta$ Ct values $\left(\mathrm{Ct}_{/ D O}{ }^{\left.-\mathrm{Ct}_{\text {actin }}\right)}\right.$ of the infected and uninfected samples was compared by Student's $t$-test. ${ }^{\star \star} P<0.01$ ${ }^{\star} P<0.05$.
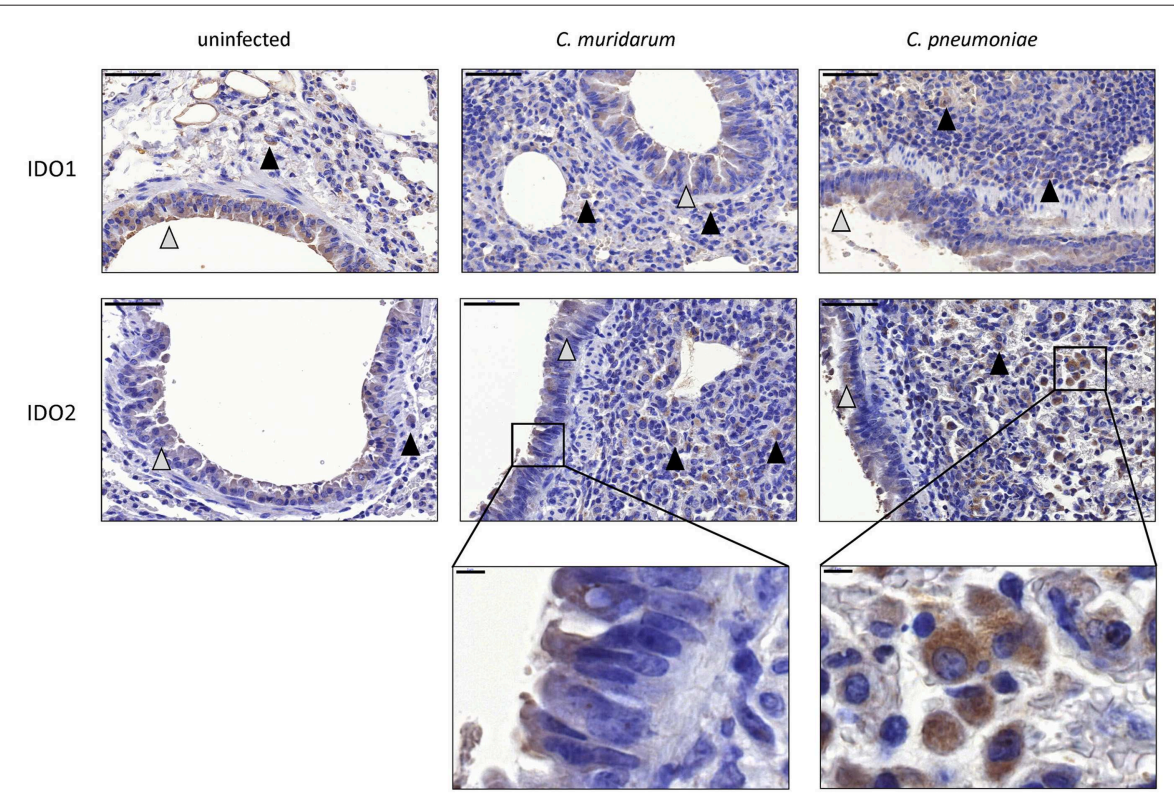

FIGURE 4 | Detection of IDO1-2 protein expressions in Chlamydia infected and uninfected BALB/c mouse lungs. IDO1 protein and IDO2 protein expressions detected by immunohistochemistry in C. muridarum infected, C. pneumoniae infected (7 days post infection) and uninfected control lung tissues. The IDO positive epithelial cells are shown by gray triangles, the IDO positive macrophages are shown by black triangles. Bars: $50 \mu \mathrm{m}$. The characteristic IDO stainings of epithelial cells and macrophages are shown in brackets. Bars: $5 \mu \mathrm{m}$.

and C. pneumoniae infected lungs contained $369.6 \pm 199.8 \mathrm{nM}$ and $508.7 \pm 176.6 \mathrm{nM}$. Since we could not control the cell numbers in the infected and control tissues, we normalized the samples by using the kynurenine/tryptophan ratios as described previously (Veres et al., 2015). The kynurenine/tryptophan ratios ranged from 0.12 to 0.22 in the C. muridarum infected samples, $0.13-0.20$ in the C. pneumoniae infected samples and it was 0 in the control samples (Figure 5A). To assess the impact of IDO activity on C. muridarum growth we inhibited IDO1-2 by 1-MT treatment starting from seven days before infection to seven days post infection (Figure 5B). 1-MT treatment lead to a moderate but significant, 1.98 

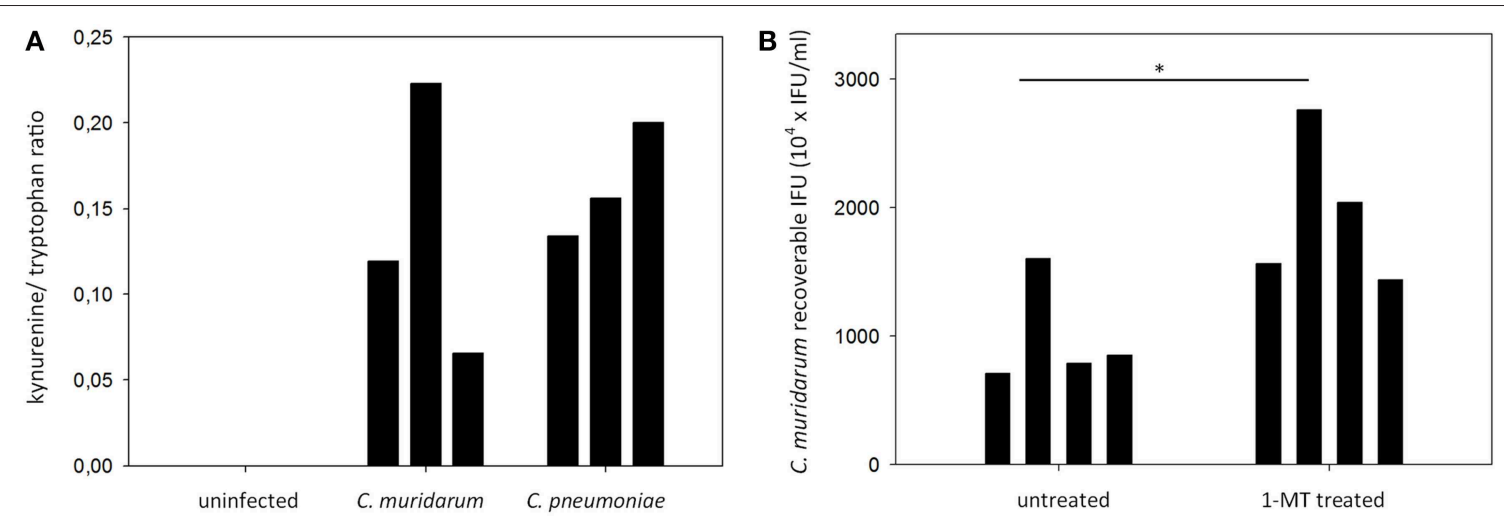

FIGURE 5 | Measurement of tryptophan degradation in the Chlamydia infected BALB/c lung tissues and the effect of IDO1-2 inhibition on C. muridarum growth. (A) C. muridarum infected, C. pneumoniae infected and uninfected lung tissues $(n=3)$ were processed as described in the Materials and Methods for kynurenine and tryptophan concentration measurements at 7 days post infection. Tryptophan degradation was described by measuring the kynurenine/tryptophan ratio.

Kynurenine/tryptophan ratios of each of the lungs analyzed are shown. Kynurenine concentrations of the uninfected samples were below the limit of detection. (B) untreated $(n=4)$ and 1-MT treated $(n=4)$ BALB/c mice were infected with $C$. muridarum and the recoverable IFUs were measured at 7 days post infection. Recoverable IFUs from each of the analyzed lungs are shown. Recoverable IFUs from untreated and 1-MT treated samples were compared by Student's $t$-test. ${ }^{\star} P<0.05$.

fold increase in C. muridarum recoverable IFU at 7 days post infection.

\section{IDO 1-2 mRNA Expression and Activity in C. muridarum Infected C57BL/6 Mouse Lung Tissues}

To explore whether the Chlamydia-induced IDO1-2 activity could be observed in another mouse strain, we performed qPCR and HPLC analyses of $C$. muridarum infected and control lung tissues of C57BL/6 mice. qPCR data showed a significant increase of IDO1 mRNA level in the C. muridarum infected lungs (fold of up-regulation range: 8.14-13.88), and while the IDO2 mRNA up-regulation was not significant, an up-regulation tendency could be observed (fold of up-regulation range: 1.71-21.49) (Figure 6A). HPLC analysis of tryptophan and kynurenine contents showed that uninfected C57BL/6 mice lungs contained a small amount of kynurenine (0.0450.075 kynurenine/tryptophan concentration ratios), and the C. muridarum infection significantly increased the IDO activity (0.185-0.773 kynurenine/tryptophan concentration ratios) (Figure 6B).

\section{DISCUSSION}

RNA sequencing analysis of the C. muridarum infected lungs revealed that the expression of a wide variety of host genes were altered, and several up-regulated genes could contribute in the Chlamydia-induced inflammation and antichlamydial defense of the murine host. Genes related to both the innate and adaptive immunity were found to be induced in the $C$. muridarum infected lung tissue. The major functional "themes" were related to cytokine/chemokine expression, chemotaxis, signal transduction, antigen presentation, cell division and innate antimicrobial defense. According to the cellular theory of chlamydial pathogenesis, non-immune cells trigger the inflammation by secreting proinflammatory cytokines and chemokines (Stephens, 2003). While the cellular source of the cytokines/chemokines cannot be identified by a tissue-level gene expression analysis, in toto the strong gene expression imprint of chemotaxis induction and cellular influx could be identified in the C. muridarum infected mouse lungs. The autocrine-paracrine effects of the secreted cytokines and the cell-to-cell interactions between resident and novel cells could result in a milieu that induced a complex gene expression including the induction of certain antichlamydial genes.

Several members of the IFN-inducible GTPase family were found to be highly induced. Although we did not measure the gene expression changes induced by the C. pneumoniae, previous studies showed that both the murine and human Chlamydia strains were able to induce IFN-inducible GTPases (Nelson et al., 2005; Burian et al., 2010). GTPases IRGM1 (LRG47), IRGM3 (IGTP), IRGA6 (IIGP), and IRGB10 were found to be upregulated or highly-upregulated, and have been shown to be involved in the clearance of the human C. trachomatis strain (Nelson et al., 2005; Bernstein-Hanley et al., 2006b; Coers et al., 2008), but likely not effective against the murine Chlamydia (Nelson et al., 2005; Coers et al., 2008). Novel GTPase genes were also found to be highly up-regulated after C. muridarum infection, and could be involved in the antichlamydial defense. Three of these genes (Gm12185, Gm5431, 9930111J21Rik1) show a sequence similarity to $I R G B 10$, a known murine defense gene against $C$. trachomatis (Bernstein-Hanley et al., 2006b). Interestingly, Coers et al. showed that $C$. muridarum was capable of evading the antichlamydial effect of IRGB10 (Coers et al., 2008). Altogether, the differential sensitivity to the IFN-inducible GTPases could explain the fact that despite using 400 fold more C. pneumoniae IFU than C. muridarum, we recovered comparable IFUs from the infected lungs. The other known antichlamydial gene iNOS was also up-regulated (14 fold). iNOS induction has been shown to 

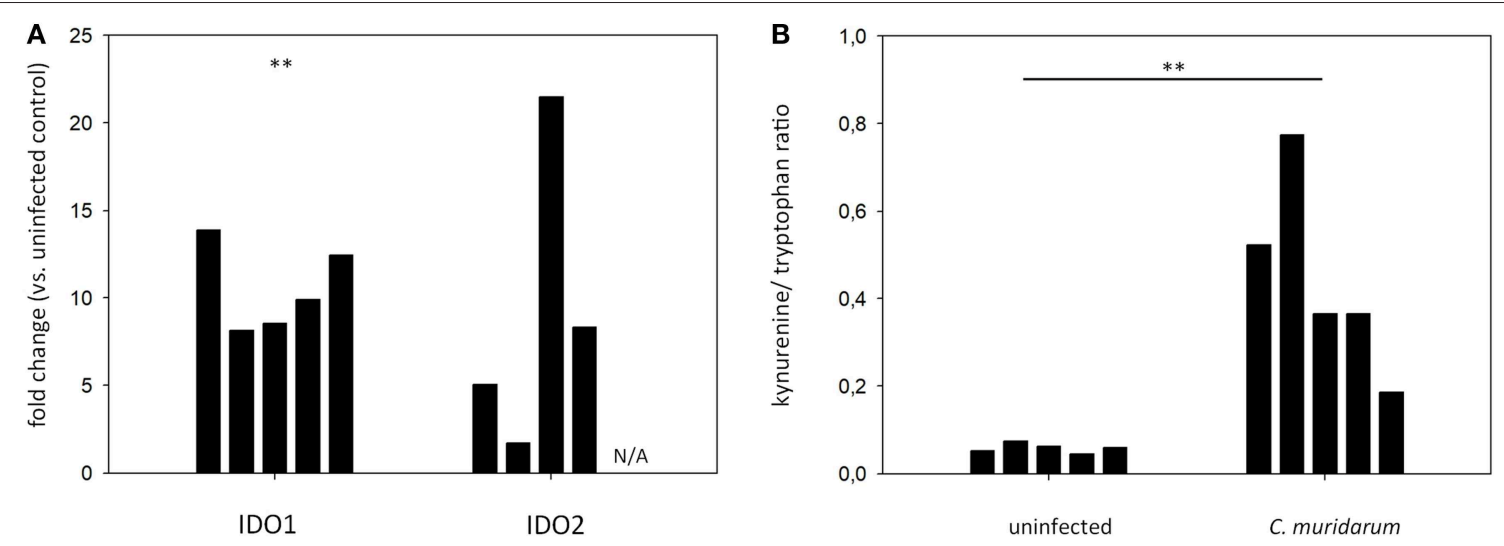

FIGURE 6 | qPCR measurement of IDO1 and IDO2 gene expressions in the C. muridarum infected C57BL/6 lung tissues (A). IDO1 and IDO2 gene expression fold changes in each infected mice $(n=5)$ were calculated by comparing the average IDO1 and IDO2 expressions in the uninfected controls $(n=5)$. IDO1 and IDO2 gene expressions were normalized by the beta-actin gene expressions. $\Delta \mathrm{Ct}$ values ( $\mathrm{Ct}_{\mathrm{IDO}} \mathrm{-Ct}_{\mathrm{actin}}$ ) of the infected and uninfected samples was compared by Student's t-test. ${ }^{\star \star} P<0.01$. N/A: IDO2 mRNA expression could not be detected. (B) Measurement of tryptophan degradation in the $C$. muridarum infected C57BL/6 lung tissues. C. muridarum infected and uninfected lung tissues $(n=5)$ were processed as described previously at 7 days post infection. Kynurenine/tryptophan concentration ratios of each of the lungs analyzed are shown. Kynurenine/tryptophan concentration ratios of $C$. muridarum infected and uninfected samples were compared by Student's $t$-test. ${ }^{\star \star} P<0.01$.

be an important mechanism in the later phase elimination of $C$. muridarum infection from the mouse genital tract (Johnson et al., 2012) and also in RAW 264.7 murine macrophages (Rajaram and Nelson, 2015). IRG1, another IFN-inducible gene (Tallam et al., 2016) (Naujoks et al., 2016) was found to be highly up-regulated (252.7 fold) after C. muridarum infection. IRG1 was shown to be expressed in macrophages (Hall et al., 2013; Naujoks et al., 2016), associated with Legionella pneumophila vacuoles in macrophages and possessed antimicrobial activity by increasing reactive oxygen species production (Hall et al., 2013) and by the direct bactericidal effect of itaconic acid production (Naujoks et al., 2016). A CXC chemokine, MIG was also highly up-regulated (127 fold) after C. muridarum infection. We showed previously that MIG had a concentration-dependent direct toxicity to the elementary bodies of C. muridarum, C. trachomatis (Burian et al., 2010) and C. pneumoniae (Balogh et al., 2011).

RNA sequencing and qPCR revealed that the IDO1 and IDO2 genes were also highly induced in the infected lungs. To identify the source of IDO activity, we performed IDO1-2 IHC in infected and control lung tissues. We found that lung bronchial epithelial cells had a moderate level of IDO1-2 positivity both in the control and infected tissues, indicating a lower-level, steady-state expression. A higher level of IDO1-2 positivity was detected in leukocytes, prominently in macrophages, in both the uninfected and infected tissues, but the number of positive cells was higher in the Chlamydia-infected tissues. The higher number of IDO1-2 positive macrophages might be a result of in situ IDO1-2 induction and/or the influx of already IDO1-2 positive monocytes into the inflamed tissue. It is also possible that the IDO1-2 positive macrophages were activated locally resulting in a higher IDO1-2 activity. Previous in vivo studies showed a tissue level IDO induction in various murine tissues infected by Escherichia coli (Loughman and Hunstad, 2012), Plasmodium berghei (Sanni et al., 1998), and Toxoplasma gondii (Fujigaki et al., 2002). Interestingly, C. pneumoniae induced lung IDO1 expression was also shown in $\mathrm{RAG}^{-/-}$mice, but not in the wild type C57BL/6 controls (Rottenberg et al., 2000). Cellular level IDO induction in vivo was detected in murine intestinal epithelial cells after Eimeria falciformis infection (Schmid et al., 2012), in lung epithelial cells after influenza A virus infection (Huang et al., 2013) and in lung epithelial cells, endothelial cells and macrophages/dendritic cells after Mycobacterium tuberculosis infection (Desvignes and Ernst, 2009). Knockout studies showed that-similarly to humans-one of the major inducers of IDO expression is IFNG and IFNA/B in murine tissues in vivo (Loughman and Hunstad, 2012; Huang et al., 2013). According to our gene expression data one of the prominent networks induced by C. muridarum infection was the IFN signaling pathway, therefore the IFN impact of IDO1-2 gene induction was clearly present in the Chlamydia-infected tissues. HPLC detection of the tryptophan degradation product kynurenine in $\mathrm{BALB} / \mathrm{c}$ lungs demonstrated that $i$, in the uninfected murine lung tissues IDO activity was not detectable, hence the low level IDO1-2 protein positivity detected in uninfected epithelial cells and macrophages did not yield significant tryptophan catabolism ii, IDO1-2 enzymes were induced and functionally active in both the murine and human Chlamydia infected lung tissues. A quantitative IHC was not performed, but the observation of similar level of IDO1-2 IHC positivity in epithelial cells before and after infection indicates that the IDO1-2 were not induced and IDO1-2 activity might not be involved in the elimination of Chlamydia from the murine lung epithelial cells. Further quantitative studies needed to clarify the exact role of murine epithelial IDO expression. The fact that the C57BL/6 mouse lungs also showed Chlamydia infection induced IDO activity supports that the observed IDO induction is not a mouse strainspecific response. 
The role of murine IDO in the clearance of Chlamydia in vivo is not well-defined. IDO1 knockout mice cleared $C$. muridarum from the urogenital tract with similar-but not identical-kinetics to the wild types (Nelson et al., 2005), but it should be noted that IDO2 gene was intact in these animals (Mellor et al., 2003; Blumenthal et al., 2012). To clarify the antimicrobial role of IDO1-2 activity we treated BALB/c mice with 1-MT, a previously described inhibitor of IDO1 (Cady and Sono, 1991) and IDO2 (Metz et al., 2007). IDO inhibition showed that there was a moderate but significant, $\sim 2$ fold increase in C. muridarum recoverable IFU in 1-MT treated mice indicating that IDO activity influenced the C. muridarum replication in vivo.

Both the C. muridarum and $C$. pneumoniae infections clearly lead to the presence of IDO1-2 positive macrophages, and this leukocyte influx/activation was a major factor in the observed increase in IDO1-2 activity. Monocytes have been implicated in the spread of $C$. pneumoniae from the primary site of infections (Beagley et al., 2009), but human monocytes were able to suppress C. trachomatis growth via IDO-dependent (Carlin and Weller, 1995) and IDO-independent mechanisms (Koehler et al., 1997; Nettelnbreker et al., 1998; Marangoni et al., 2014). Whether the IDO activity of murine macrophages contributes to the control of C. muridarum and C. trachomatis growth, needs further investigation.

There are limitations of our study that need further investigations. We could not detect IDO 1-2 inducibility in epithelial cells, but the applied IHC was not a quantitative method. Since epithelial cells are the sites of chlamydial replication, the isolation of lung epithelial cells and the measurement of their steady state and infection-induced IDO activity are critical points and a goal we are currently pursuing. The other obvious targets to assess IDO activity are the isolated epithelial cells of the uninfected and infected murine urogenital tract. The role of IDO2 is not defined. The lung IDO2 mRNA was clearly induced by Chlamydia infection, but its RNA-seq read numbers were significantly lower than IDO1 reads. In order to assess the potential role of IDO2, the IDO2 protein concentrations in isolated lung epithelial cells and macrophages has to be measured and compared to IDO1. Also, chemical inhibition of IDO showed a significant, albeit limited phenotypic effect. This could be due to the limited defensive role of IDO 1-2 or the incomplete inhibition of the enzymes. Further studies with optimized IDO inhibition protocol and more time points post infection are needed.

Chlamydia can avoid intracellular defense responses by using metabolic shunt (Aiyar et al., 2014), inactivating cellular effector proteins such as IFN-inducible GTPases

\section{REFERENCES}

Aiyar, A., Quayle, A. J., Buckner, L. R., Sherchand, S. P., Chang, T. L., Zea, A. $\mathrm{H}$., et al. (2014). Influence of the tryptophan-indole-IFN $\gamma$ axis on human
(Nelson et al., 2005; Coers et al., 2008), or avoiding the induction of the intracellular effectors (Marangoni et al., 2014). Our in vivo study showed that -at the tissue level- various antibacterial mechanisms are switched on and IDO1-2 could be part of this effector repertoire.

\section{DATA AVAILABILITY}

The raw data analyzed in this study can be found in the Gene Expression Omnibus (GEO) database (GSE124007). The lists of differentially expressed genes are included in the Supplementary Table 1.

\section{ETHICS STATEMENT}

The experiments were approved by the Animal Welfare Committee of the University of Szeged and conform to the Directive 2010/63/EU of the European Parliament.

\section{AUTHOR CONTRIBUTIONS}

DV designed the experiments, analyzed the RNA-seq data and prepared the manuscript. $\mathrm{KB}, \mathrm{TR}$, and $\mathrm{VE}$ were involved in designing the experiments, performed the animal infections, tissue extraction, Chlamydia growth monitoring, histology, and manuscript preparation. $\mathrm{DK}, \mathrm{DP}$, and $\mathrm{AB}$ were involved in manuscript preparation, identification of novel GTPases and phylogeny of GTPases. LT performed the histology and IDO12 immunohistochemistry. LV and GV performed the kynurenine and tryptophan HPLC measurements. LV critically reviewed the manuscript. SP performed the RNA sequencing, identification of differentially expressed genes, collection and comparison of IDO1 and IDO2 raw data. FS performed the IDO1-2 primer designs, IDO1-2 qPCRs and was involved in higher level RNAseq analysis.

\section{FUNDING}

The study was supported by the EFOP-3.6.1-16-2016-00008 European Union-Hungary grant and the UNKP-18-3 New National Excellence Program of the Ministry of Human Capacities, Hungary.

\section{SUPPLEMENTARY MATERIAL}

The Supplementary Material for this article can be found online at: https://www.frontiersin.org/articles/10.3389/fcimb. 2019.00192/full\#supplementary-material

Supplementary Table 1 | Differentially expressed genes in C. muridarum infected vs. uninfected BALB/c lung tissues. 
MIG/CXCL9, which has in vitro antichlamydial activity. Int. J. Med. Microbiol. 301, 252-259. doi: 10.1016/j.ijmm.2010.08.020

Beagley, K. W., Huston, W. M., Hansbro, P. M., and Timms, P. (2009). Chlamydial infection of immune cells: altered function and implications for disease. Crit. Rev. Immunol. 29, 275-305. doi: 10.1615/CritRevImmunol.v29.i4.10

Bernstein-Hanley, I., Balsara, Z. R., Ulmer, W., Coers, J., Starnbach, M. N., and Dietrich, W. F. (2006a). Genetic analysis of susceptibility to Chlamydia trachomatis in mouse. Genes Immun. 7, 122-129. doi: 10.1038/sj.gene.6364285

Bernstein-Hanley, I., Coers, J., Balsara, Z. R., Taylor, G. A., Starnbach, M. N., and Dietrich, W. F. (2006b). The p47 GTPases Igtp and Irgb10 map to the Chlamydia trachomatis susceptibility locus Ctrq-3 and mediate cellular resistance in mice. Proc. Natl. Acad. Sci. U.S.A. 103, 14092-14097. doi: 10.1073 /pnas.0603338103

Blumenthal, A., Nagalingam, G., Huch, J. H., Walker, L., Guillemin, G. J., Smythe, G. A., et al. (2012). M. tuberculosis induces potent activation of IDO-1, but this is not essential for the immunological control of infection. PLOS ONE 7:e37314. doi: 10.1371/journal.pone.0037314

Burian, K., Endresz, V., Deak, J., Kormanyos, Z., Pal, A., Nelson, D., et al. (2010). Transcriptome analysis indicates an enhanced activation of adaptive and innate immunity by chlamydia-infected murine epithelial cells treated with interferon $\gamma$. J. Infect. Dis. 202, 1405-1414. doi: 10.1086/ 656526

Burián, K., Hegyesi, H., Buzás, E., Endrész, V., Kis, Z., Falus, A., et al. (2003). Chlamydophila (Chlamydia) pneumoniae induces histidine decarboxylase production in the mouse lung. Immunol. Lett. 89, 229-236. doi: 10.1016/S0165-2478(03)00154-8

Byrne, G. I., Lehmann, L. K., and Landry, G. J. (1986). Induction of tryptophan catabolism is the mechanism for gamma-interferon-mediated inhibition of intracellular Chlamydia psittaci replication in T24 cells. Infect. Immun. 53, 347-351.

Cady, S. G., and Sono, M. (1991). 1-Methyl-DL-tryptophan, beta-(3benzofuranyl)-DL-alanine (the oxygen analog of tryptophan), and beta-[3-benzo(b)thienyl]-DL-alanine (the sulfur analog of tryptophan) are competitive inhibitors for indoleamine 2,3-dioxygenase. Arch. Biochem. Biophys. 291, 326-333.

Caldwell, H. D., Kromhout, J., and Schachter, J. (1981). Purification and partial characterization of the major outer membrane protein of Chlamydia trachomatis. Infect. Immun. 31, 1161-1176.

Carlin, J. M., and Weller, J. B. (1995). Potentiation of interferon-mediated inhibition of Chlamydia infection by interleukin-1 in human macrophage cultures. Infect. Immun. 63, 1870-1875.

Centers for Disease Control and Prevention (2014). Prevalence of Chlamydia Trachomatis Genital Infection Among Persons Aged 14-39 Years United States, 2007-2012. Available online at: https://www.cdc.gov/mmwr/ preview/mmwrhtml/mm6338a3.htm (accessed February 28, 2017).

Coers, J., Bernstein-Hanley, I., Grotsky, D., Parvanova, I., Howard, J. C., Taylor, G. A., et al. (2008). Chlamydia muridarum evades growth restriction by the IFNgamma-inducible host resistance factor Irgb10. J. Immunol. Baltim. Md 1950 180, 6237-6245. doi: 10.4049/jimmunol.180.9.6237

Desvignes, L., and Ernst, J. D. (2009). Interferon-gamma-responsive nonhematopoietic cells regulate the immune response to Mycobacterium tuberculosis. Immunity 31, 974-985. doi: 10.1016/j.immuni.2009.10.007

Finethy, R., and Coers, J. (2016). Sensing the enemy, containing the threat: cellautonomous immunity to Chlamydia trachomatis. FEMS Microbiol. Rev. 40, 875-893. doi: 10.1093/femsre/fuw027

Fujigaki, S., Saito, K., Takemura, M., Maekawa, N., Yamada, Y., Wada, H., et al. (2002). L-tryptophan-L-kynurenine pathway metabolism accelerated by Toxoplasma gondii infection is abolished in gamma interferon-genedeficient mice: cross-regulation between inducible nitric oxide synthase and indoleamine-2,3-dioxygenase. Infect. Immun. 70, 779-786. doi: 10.1128/IAI.70. 2.779-786.2002

Hall, C. J., Boyle, R. H., Astin, J. W., Flores, M. V., Oehlers, S. H., Sanderson, L. E., et al. (2013). Immunoresponsive gene 1 augments bactericidal activity of macrophage-lineage cells by regulating $\beta$-oxidation-dependent mitochondrial ROS production. Cell Metab. 18, 265-278. doi: 10.1016/j.cmet.2013.06.018

Hervé, C., Beyne, P., Jamault, H., and Delacoux, E. (1996). Determination of tryptophan and its kynurenine pathway metabolites in human serum by high-performance liquid chromatography with simultaneous ultraviolet and fluorimetric detection. J. Chromatogr. B. Biomed. Sci. App. 675, 157-161. doi: 10.1016/0378-4347(95)00341-X

Huang, L., Li, L., Klonowski, K. D., Tompkins, S. M., Tripp, R. A., and Mellor, A. L. (2013). Induction and role of indoleamine 2,3 dioxygenase in mouse models of influenza a virus infection. PLoS ONE 8:e66546. doi: 10.1371/journal.pone.0066546

Johnson, R. M., Kerr, M. S., and Slaven, J. E. (2012). Plac8-dependent and inducible NO synthase-dependent mechanisms clear Chlamydia muridarum infections from the genital tract. J. Immunol. Baltim. 188, 1896-1904. doi: 10.4049/jimmunol.1102764

Kis, Z., Burian, K., Treso, B., Acs, K., Prohaszka, Z., Fust, G., et al. (2008). Inflammatory- and immune responses in relation to bacterial replication in mice following re-infections with Chlamydophila pneumoniae. Inflamm. Res. Off. J. Eur. Histamine Res. Soc. Al. 57, 287-295. doi: 10.1007/s00011-007-7124-0

Koehler, L., Nettelnbreker, E., Hudson, A. P., Ott, N., Gérard, H. C., Branigan, P. J., et al. (1997). Ultrastructural and molecular analyses of the persistence of Chlamydia trachomatis (serovar K) in human monocytes. Microb. Pathog. 22, 133-142. doi: 10.1006/mpat.1996.0103

Kong, F. Y. S., Tabrizi, S. N., Law, M., Vodstrcil, L. A., Chen, M., Fairley, C. K., et al. (2014). Azithromycin versus doxycycline for the treatment of genital chlamydia infection: a meta-analysis of randomized controlled trials. Clin. Infect. Dis. 59, 193-205. doi: 10.1093/cid/ciu220

Kuleshov, M. V., Jones, M. R., Rouillard, A. D., Fernandez, N. F., Duan, Q., Wang, Z., et al. (2016). Enrichr: a comprehensive gene set enrichment analysis web server 2016 update. Nucleic Acids Res. 44, 90-97. doi: 10.1093/nar/ gkw377

Lallemand, A., Bremer, V., Jansen, K., Nielsen, S., Münstermann, D., Lucht, A., et al. (2016). Prevalence of Chlamydia trachomatis infection in women, heterosexual men and MSM visiting HIV counselling institutions in North Rhine-Westphalia, Germany - should Chlamydia testing be scaled up? BMC Infect. Dis. 16:610. doi: 10.1186/s12879-0161915-2

Loughman, J. A., and Hunstad, D. A. (2012). Induction of indoleamine 2,3-dioxygenase by uropathogenic bacteria attenuates innate responses to epithelial infection. J. Infect. Dis. 205, 1830-1839. doi: 10.1093/infdis/ jis 280

Marangoni, A., Bergamini, C., Fato, R., Cavallini, C., Donati, M., Nardini, P., et al. (2014). Infection of human monocytes by Chlamydia pneumoniae and Chlamydia trachomatis: an in vitro comparative study. BMC Res. Notes 7:230. doi: 10.1186/1756-0500-7-230

Mariotti, S. P., Pascolini, D., and Rose-Nussbaumer, J. (2009). Trachoma: global magnitude of a preventable cause of blindness. Br. J. Ophthalmol. 93, 563-568. doi: 10.1136/bjo.2008.148494

Mellor, A. L., Baban, B., Chandler, P., Marshall, B., Jhaver, K., Hansen, A., et al. (2003). Cutting edge: induced indoleamine 2,3 dioxygenase expression in dendritic cell subsets suppresses $\mathrm{T}$ cell clonal expansion. J. Immunol. Baltim. Md 1950 171, 1652-1655. doi: 10.4049/jimmunol.171.4.1652

Metz, R., Duhadaway, J. B., Kamasani, U., Laury-Kleintop, L., Muller, A. J., and Prendergast, G. C. (2007). Novel tryptophan catabolic enzyme IDO2 is the preferred biochemical target of the antitumor indoleamine 2,3-dioxygenase inhibitory compound D-1-methyl-tryptophan. Cancer Res. 67, 7082-7087. doi: 10.1158/0008-5472.CAN-07-1872

Naujoks, J., Tabeling, C., Dill, B. D., Hoffmann, C., Brown, A. S., Kunze, M., et al. (2016). IFNs modify the proteome of legionella-containing vacuoles and restrict infection via IRG1-derived itaconic acid. PLoS Pathog. 12:e1005408. doi: 10.1371/journal.ppat.1005408

Nelson, D. E., Virok, D. P., Wood, H., Roshick, C., Johnson, R. M., Whitmire, W. M., et al. (2005). Chlamydial IFN-gamma immune evasion is linked to host infection tropism. Proc. Natl. Acad. Sci. U.S.A. 102, 10658-10663. doi: 10.1073/pnas.0504198102

Nettelnbreker, E., Zeidler, H., Bartels, H., Dreses-Werringloer, U., Däubener, W., Holtmann, H., et al. (1998). Studies of persistent infection by Chlamydia trachomatis serovar K in TPA-differentiated U937 cells and the role of IFNgamma. J. Med. Microbiol. 47, 141-149. doi: 10.1099/00222615-47-2-141

R Core Team (2014). R: A Language and Environment for Statistical Computing. Vienna: R Foundation for Statistical Computing.

Rajaram, K., and Nelson, D. E. (2015). Chlamydia muridarum infection of macrophages elicits bactericidal nitric oxide production via reactive 
oxygen species and cathepsin B. Infect. Immun. 83, 3164-3175. doi: 10.1128/IAI.00382-15

Roshick, C., Wood, H., Caldwell, H. D., and McClarty, G. (2006). Comparison of gamma interferon-mediated antichlamydial defense mechanisms in human and mouse cells. Infect. Immun. 74, 225-238. doi: 10.1128/IAI.74.1.225-238.2006

Rottenberg, M. E., Gigliotti Rothfuchs, A., Gigliotti, D., Ceausu, M., Une, C., Levitsky, V., et al. (2000). Regulation and role of IFN-gamma in the innate resistance to infection with Chlamydia pneumoniae. J. Immunol. 164, 4812-4818. doi: 10.4049/jimmunol.164.9.4812

Sanni, L. A., Thomas, S. R., Tattam, B. N., Moore, D. E., Chaudhri, G., Stocker, R., et al. (1998). Dramatic changes in oxidative tryptophan metabolism along the kynurenine pathway in experimental cerebral and noncerebral malaria. Am. J. Pathol. 152, 611-619.

Santamaría, R., and Pierre, P. (2012). Voronto: mapper for expression data to ontologies. Bioinforma. Oxf. Engl. 28, 2281-2282. doi: 10.1093/bioinformatics/bts428

Schmid, M., Lehmann, M. J., Lucius, R., and Gupta, N. (2012). Apicomplexan parasite, Eimeria falciformis, co-opts host tryptophan catabolism for life cycle progression in mouse. J. Biol. Chem. 287, 20197-20207. doi: 10.1074/jbc.M112.351999

Stephens, R. S. (2003). The cellular paradigm of chlamydial pathogenesis. Trends Microbiol. 11, 44-51. doi: 10.1016/S0966-842X(02)00011-2

Tallam, A., Perumal, T. M., Antony, P. M., Jäger, C., Fritz, J. V., Vallar, L., et al. (2016). Gene Regulatory Network Inference of Immunoresponsive Gene 1 (IRG1) Identifies Interferon Regulatory Factor 1 (IRF1) as its transcriptional regulator in mammalian macrophages. PLoS ONE 11:e0149050. doi: 10.1371/journal. pone. 0149050

Thorvaldsdóttir, H., Robinson, J. T., and Mesirov, J. P. (2013). Integrative Genomics Viewer (IGV): high-performance genomics data visualization and exploration. Brief. Bioinform. 14, 178-192. doi: 10.1093/ bib/bbs017

Veres, G., Molnár, M., Zádori, D., Szentirmai, M., Szalárdy, L., Török, R., et al. (2015). Central nervous system-specific alterations in the tryptophan metabolism in the 3-nitropropionic acid model of Huntington's disease. Pharmacol. Biochem. Behav. 132, 115-124. doi: 10.1016/j.pbb.20 15.03.002

Yuan, J. S., Reed, A., Chen, F., and Stewart, C. N. (2006). Statistical analysis of real-time PCR data. BMC Bioinformatics 7:85. doi: 10.1186/1471-21 05-7-85

Conflict of Interest Statement: The authors declare that the research was conducted in the absence of any commercial or financial relationships that could be construed as a potential conflict of interest.

Copyright (c) 2019 Virok, Raffai, Kókai, Paróczai, Bogdanov, Veres, Vécsei, Poliska, Tiszlavicz, Somogyvári, Endrész and Burián. This is an open-access article distributed under the terms of the Creative Commons Attribution License (CC BY). The use, distribution or reproduction in other forums is permitted, provided the original author(s) and the copyright owner(s) are credited and that the original publication in this journal is cited, in accordance with accepted academic practice. No use, distribution or reproduction is permitted which does not comply with these terms. 


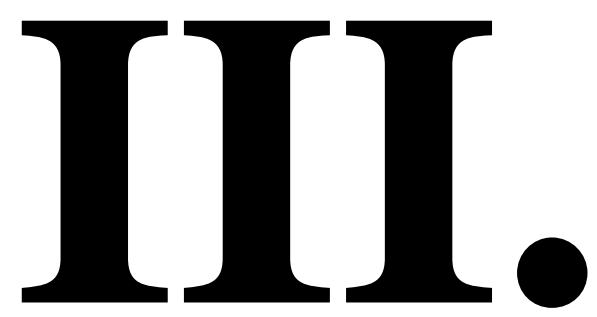




\title{
14-Noreudesmanes and a phenylpropane heterodimer from sea buckthorn berry inhibit Herpes simplex type 2 virus replication
}

\author{
Dóra Rédei ${ }^{\mathrm{a}, \mathrm{b}}$, Norbert Kúsz ${ }^{\mathrm{a}}$, Tímea Rafai ${ }^{\mathrm{c}}$, Anita Bogdanov ${ }^{\mathrm{c}}$, Katalin Burián ${ }^{\mathrm{c}}$, \\ Attila Csorba a , Attila Mándi d, Tibor Kurtán d, Andrea Vasas a, b, Judit Hohmann a, b, * \\ a Department of Pharmacognosy, Interdisciplinary Excellence Centre, University of Szeged, 6720 Szeged, Hungary \\ ${ }^{\mathrm{b}}$ Interdisciplinary Centre of Natural Products, University of Szeged, 6720 Szeged, Hungary \\ ${ }^{\mathrm{c}}$ Department of Medical Microbiology and Immunobiology, University of Szeged, 6720 Szeged, Hungary \\ d Department of Organic Chemistry, University of Debrecen, 4032 Debrecen, Hungary
}

\section{A R T I C L E I N F O}

\section{Article history:}

Received 12 July 2018

Received in revised form

18 January 2019

Accepted 22 January 2019

Available online 24 January 2019

\section{Keywords:}

Elaeagnus rhamnoides

Hippophae rhamnoides

Sea buckthorn

Noreudesmane

Phenylpropane dimer

Anti-HSV2-activity

\begin{abstract}
A B S T R A C T
Two new 14-noreudesmane sesquiterpenes, one new phenylpropane heterodimer, caulilexin $C$, and uvaol were isolated from the $70 \% \mathrm{MeOH}$ extract of the fruit peel of Elaeagnus rhamnoides. The structures of the compounds were elucidated by HRESIMS and advanced NMR methods. The absolute configuration of (R)-6,9-dihydroxy-1-oxo-14-noreudesm-5,7,9-triene was determined by the TDDFT-ECD method. The new compounds, together with structurally similar naphthalenes (musizin, musizin-8-O-glucoside, torachrysone-8-O-glucoside) and 1,4-naphthoquinone (2-methylstipandrone), isolated previously from Rumex aquaticus, were investigated for their antiviral activity against Herpes simplex virus type 2 (HSV-2) using two different methods. Applying the traditional virus yield reduction test, $(R)$-6,9-dihydroxy-1oxo-14-noreudesm-5,7,9-triene, 1-[3-methoxy-4-(2-methoxy-4-(1E)-propenyl-phenoxy)-phenyl]-propane-1,2-diol, and musizin caused a $2.00 \log _{10}, 3.49 \log _{10}$, and $2.33 \log _{10}$ reduction of HSV-2 yield, respectively, at a concentration of $12.5 \mu \mathrm{M}$. 2-Hydroxy-1-methoxy-6,9-dioxo-14-noreudesm-1,3,5(10),7tetraene exhibited an antiviral effect at concentration of $50 \mu \mathrm{M}$ only. Similar results were obtained when the qPCR method was used to test the antiviral activity of the compounds.
\end{abstract}

() 2019 Published by Elsevier Ltd.

\section{Introduction}

Sea buckthorn [Elaeagnus rhamnoides (L.) A.Nelson, syn. Hippophae rhamnoides L.] belonging to the Elaeagnaceae family, is native to many European and Asian countries, and is cultivated on a production scale in several countries, including Russia, China, Sweden, Finland, Norway, Estonia, Germany, and Hungary. The berries of sea buckthorn have gained attention worldwide, mainly for their nutritional and medicinal values. The fruit of $E$. rhamnoides is well-known for its antioxidant activity that can be attributed to its high ascorbic acid, flavonoid, proanthocyanidin, and carotenoid content $[1,2]$. Further important nutritive constituents include vitamins (A, E, K, riboflavin, pyridoxine, thiamine, folic acid), fatty oil, unsaturated fatty acids, organic acids, amino acids, proteins, and minerals [1,3]. Furthermore, many bioactive compounds have also

\footnotetext{
* Corresponding author. Department of Pharmacognosy, Interdisciplinary Excellence Centre, University of Szeged, 6720 Szeged, Hungary.

E-mail address: hohmann@pharm.u-szeged.hu (J. Hohmann).
}

been isolated and identified from the berries, such as triterpenoids, phytosterols, essential oil, cerebrosides, 5-hydroxytryptamine, lignans, and phenylcarboxylic acids [4,5].

In our previous study on sea buckthorn, the fruit peel was analysed for anti-inflammatory compounds by an activity-guided isolation procedure using the $48 / 80$ assay. Ursolic and oleanolic acids were identified as the agents responsible for the antiinflammatory activity of the lipophilic peel extract, and the presence of 2,6-bis-aryl-tetrahydrofuran-type stereoisomeric lignans was also confirmed [6]. As an extension of this series of experiment, further compounds were isolated from the $\mathrm{CHCl}_{3}$ soluble fraction of the $\mathrm{MeOH}$ extract of the fruit peel. The present paper reports the isolation of two new sesquiterpenes $(\mathbf{1}, \mathbf{2})$ with a 14-noreudesmane skeleton, one new phenylpropane heterodimer (3), as well as caulilexin C (4), and uvaol. The new compounds (1-3) were investigated for their antiviral activity against HSV-2 by the traditional virus yield reduction assay and also by the direct qPCR method. Some structurally related naphthalenes [musizin (5), musizin-8-O-glucoside (6), torachrysone-8-O-glucoside (7)] and a 
naphthoquinone (2-methylstipandrone, 8) isolated from Rumex aquaticus [7] were also involved in the antiviral evaluation in order to gain a broader insight into the relative biological activities of the compounds.

\section{Results and discussion}

\subsection{Structure elucidation of the isolated compounds}

Combining different chromatographic methods, including column chromatography (CC), vacuum liquid chromatography (VLC), centrifugal planar chromatography (CPC), and preparative thinlayer chromatography (TLC), two nor-sesquiterpenes $(\mathbf{1}, \mathbf{2})$, a phenylpropane dimer (3), caulilexin C (4), and uvaol were isolated from the $\mathrm{CHCl}_{3}$-soluble phase of the $\mathrm{MeOH}$ extract prepared from the fruit peel of $E$. rhamnoides (Fig. 1). Structure elucidation was carried out by extensive spectroscopic analysis, including 1D and 2D NMR $\left({ }^{1} \mathrm{H}-{ }^{1} \mathrm{H}\right.$ COSY, HSQC, HMBC and NOESY) and HRESIMS experiments. The absolute configuration of $\mathbf{1}$ was determined by ECD spectroscopy.

Compound 1 was isolated as an amorphous solid with $[\alpha]_{\mathrm{D}}^{26}-18$ (c $0.2, \mathrm{MeOH}$ ). The HRESIMS measurement revealed that it had the molecular formula $\mathrm{C}_{14} \mathrm{H}_{18} \mathrm{O}_{3}$ compatible with the pseudomolecular ion peak at $m / z 235.1329[\mathrm{M}+\mathrm{H}]^{+}$(calcd for $\mathrm{C}_{14} \mathrm{H}_{19} \mathrm{O}_{3} 235.1329$ ). The ${ }^{1}$ HNMR, JMOD and HSQC spectra of 1 revealed the presence of three methyl groups, two methylenes, three methines, six nonprotonated carbons including a keto moiety $\left(\delta_{\mathrm{C}} 203.8\right)$, and two hydroxy groups $\left(\delta_{\mathrm{H}} 4.66 \mathrm{~s}, 12.24 \mathrm{~s}\right)$, as listed in Table 1 . The ${ }^{1} \mathrm{H}-{ }^{1} \mathrm{H}$ COSY spectrum defined two structural fragments with correlated protons: an isopropyl group $\left[\delta_{\mathrm{H}} 3.17 \mathrm{sept}(1 \mathrm{H}), 2 \times 1.23 \mathrm{~d}(6 \mathrm{H})\right]$ and the structural part $-\mathrm{CH}_{2}-\mathrm{CH}_{2}-\mathrm{CH}\left(\mathrm{CH}_{3}\right)-\left[\delta_{\mathrm{H}} 2.56 \mathrm{ddd}, 2.85 \mathrm{ddd}\right.$, $2.25 \mathrm{~m}, 1.97 \mathrm{app} \mathrm{dt}, 3.37 \mathrm{ddq}$ (each $1 \mathrm{H})$, and $1.33 \mathrm{~d}(3 \mathrm{H})],[\mathrm{C}-2-\mathrm{C}-$ 3-C-4(C-15)] (Fig. 2). The four-carbon fragment, together with the keto group and the nonprotonated $\mathrm{sp}^{2}$ carbons at $\delta_{\mathrm{C}} 133.4(\mathrm{C}-5)$ and 113.4 (C-10) form a six-membered ring as indicated by the HMBC correlations between $\mathrm{C}-5$ and $\mathrm{H}-3 \mathrm{~b}, \mathrm{H}-4$, and $\mathrm{H}-15, \mathrm{C}-10$ and $\mathrm{H}-4$, and between $\mathrm{C}-1, \mathrm{H}-2 \mathrm{a}, \mathrm{b}$, and $\mathrm{H}-3 \mathrm{~b}$. Three further nonprotonated
Table 1

${ }^{1} \mathrm{H}$ and ${ }^{13} \mathrm{C}$ NMR spectroscopic data of compounds $\mathbf{1}$ and $\mathbf{2}$ [CDCl $\left.3, \delta(\mathrm{ppm}),(\mathrm{J}=\mathrm{Hz})\right]$.

\begin{tabular}{llllll}
\hline Position & $\mathbf{1}^{\mathrm{a}}$ & & & $\mathbf{2}^{\mathrm{b}}$ & \\
\cline { 2 - 3 } \cline { 5 - 6 } & ${ }^{1} \mathrm{H}$ & ${ }^{13} \mathrm{C}$ & & ${ }^{1} \mathrm{H}$ & ${ }^{13} \mathrm{C}$ \\
\hline 1 & - & 203.8 & - & 144.8 \\
2 & $2.56 \mathrm{ddd}(15.4,4.3,2.1)$ & 32.6 & - & 153.8 \\
& $2.85 \mathrm{ddd}(15.4,5.4,2.1)$ & & & \\
3 & $2.25 \mathrm{~m}$ & 28.1 & & $7.01 \mathrm{~s}$ & 123.2 \\
& $1.97 \mathrm{app} \mathrm{dt}(13.5,2.2)$ & & & \\
4 & $3.37 \mathrm{ddq}(6.7,2.2,7.1)$ & 26.3 & - & 140.2 \\
5 & - & 133.4 & - & 124.2 \\
6 & - & 141.1 & - & 185.8 \\
7 & - & 145.4 & - & 157.7 \\
8 & $6.70 \mathrm{~s}$ & 112.1 & $6.52 \mathrm{~s}$ & 131.9 \\
9 & - & 157.0 & - & 185.7 \\
10 & - & 113.4 & - & 125.2 \\
11 & $3.17 \mathrm{sept}(6.9)$ & 27.5 & $3.14 \mathrm{sept}(7.0)$ & 26.8 \\
12 & $1.23 \mathrm{~d}(6.9)$ & 21.7 & & $1.10 \mathrm{~d}(7.0)$ & 21.6 \\
13 & $1.23 \mathrm{~d}(6.9)$ & 21.8 & $1.10 \mathrm{~d}(7.0)$ & 21.6 \\
15 & $1.33 \mathrm{~d}(7.1)$ & 17.8 & $2.60 \mathrm{~s}$ & 23.6 \\
$1-\mathrm{OCH}{ }_{3}$ & - & - & $3.85 \mathrm{~s}$ & 62.1 \\
$6-\mathrm{OH}$ & $4.66 \mathrm{~s}$ & - & - & - \\
$9-\mathrm{OH}$ & $12.24 \mathrm{~s}$ & - & - & - \\
\hline
\end{tabular}

a $500\left({ }^{1} \mathrm{H}\right), 125\left({ }^{13} \mathrm{C}\right) \mathrm{MHz}$

b $600\left({ }^{1} \mathrm{H}\right), 150\left({ }^{13} \mathrm{C}\right) \mathrm{MHz}$

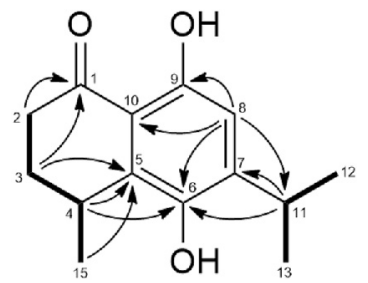

Fig. 2. Key $2 \mathrm{D}$ NMR correlations of compound 1; bold line: ${ }^{1} \mathrm{H}-{ }^{1} \mathrm{H}$ COSY; arrows: HMBC $(\mathrm{H} \rightarrow \mathrm{C})$.<smiles>CC(C)c1cc(O)c2c(c1O)[C@H](C)CCC2=O</smiles>

$(R)-1$<smiles>COc1c(O)cc(C)c2c1C(=O)C(C(C)C)=CC2=O</smiles><smiles>C/C=C/c1ccc(Oc2ccc(C(O)C(C)O)cc2OC)c(OC)c1</smiles>

threo-3<smiles>COn1cc(CC#N)c2ccccc21</smiles>

4<smiles>[R1]c1cc([R2])c2c(O)c(C(C)=O)c(C)cc2c1</smiles>

$5 \mathrm{R}^{1}=\mathrm{H}, \mathrm{R}^{2}=\mathrm{H}$

$6 \mathrm{R}^{1}=\mathrm{H}, \mathrm{R}^{2}=\mathrm{glu}$

$7 \mathrm{R}^{1}=\mathrm{OCH}_{3}, \mathrm{R}^{2}=\mathrm{glu}$<smiles>COC1=CC(=O)c2c(cc(C)c(C(C)=O)c2O)C1=O</smiles>

8

Fig. 1. Structures of compounds 1-8. 
carbons $\left(\delta_{\mathrm{C}} 141.1,145.4\right.$ and 157.0) and an aromatic methine group $\left(\delta_{\mathrm{H}} 6.70 \mathrm{~s}, \delta_{\mathrm{C}} 112.1\right)$, together with $\mathrm{C}-5$ and $\mathrm{C}-10$ construct a benzene ring, substituted with two hydroxy and one isopropyl groups, as supported by the two- and three-bond heteronuclear correlations between $\mathrm{C}-10$ and $\mathrm{H}-8, \mathrm{C}-6$ and $\mathrm{H}-8$, and $\mathrm{C}-9$ and $\mathrm{H}-8$. The HMBC cross-peaks between C-10 and H-8, C-6 and H-4, C-7 and H-11, C-6 and $\mathrm{H}-11$, and $\mathrm{C}-11$ and $\mathrm{H}-8$ established the position of the isopropyl group at C-7. The hydroxy group at $\delta_{\mathrm{H}} 12.24 \mathrm{ppm}$ should be in the peri position in relation to the keto group at $C-1$, while the hydroxy resonating at $\delta_{\mathrm{H}} 4.66 \mathrm{ppm}$ was of necessity placed to C-6. All of these data confirmed the structure of this compound as 6,9dihydroxy-1-oxo-14-noreudesm-5,7,9-triene (1).

For chiral non-racemic 1 -tetralone derivatives, the $n-\pi^{*}$ transition appearing usually above $300 \mathrm{~nm}$ can be used to determine the absolute configuration from the measured ECD spectrum by applying the helicity rule of 1 -tetralone. According to this rule, $P$ helicity of the condensed carbocyclic ring results in a positive $n-\pi^{*}$ Cotton effect (CE) [8-10]. $P$ or $M$ helicity of the condensed ring is governed by the preferred equatorial or axial orientation of the substituent(s), and thus the central chirality. When there is a hydroxy group chelating to the peri carbonyl oxygen $(9-\mathrm{OH}$ in $\mathbf{1})$ and the benzene ring contains other auxochrome substituents such as an alkoxy or hydroxy group, the $n-\pi^{*} E C D$ transition shifts to the blue, and overlaps with other $\pi-\pi^{*}$ transitions, which makes the application of the helicity rule ambiguous $[10,11]$. Similarly, when there is no clear preference for the equatorial/axial orientation of the substituents, the semi-empirical ECD approach needs support from the TDDFT-ECD calculation [12]. Since compound 1 contained a chelating 9-OH group and an additional auxochrome 6-OH, and the equatorial/axial orientation of the $15-\mathrm{CH}_{3}$ group was not evident from the NMR data, the solution TDDFT-ECD approach was utilized to determine the absolute configuration [13,14].

The initial Merck Molecular Force Field (MMFF) conformational search of $(R)-1$ resulted in 10 conformers in a $21 \mathrm{~kJ} / \mathrm{mol}$ energy window. These conformers were reoptimized at three different levels; the B3LYP/6-31G(d), the B97D/TZVP PCM/MeCN and the CAM-B3LYP/TZVP PCM/MeCN levels, each yielding 5 low-energy conformers over $1 \%$ Boltzmann populations (Fig. S1). These lowenergy conformers differed in the orientation of the $6-\mathrm{OH}$ and isopropyl groups, and the C-4 methyl group had an axial orientation with $P$ helicity of the fused cyclohexenone ring in all of them $[15,16] . P$ helicity is defined by the positive value of dihedral angle $\omega_{\mathrm{C} 5, \mathrm{C} 4, \mathrm{C} 3, \mathrm{C} 2}$, which had $+52.8^{\circ}$ value for the lowest-energy conformer optimized at the CAM-B3LYP/TZVP PCM/MeCN level. ECD calculations for all sets of conformers at various levels of theory (B3LYP/TZVP, BH\&HLYP/TZVP, CAM-B3LYP/TZVP and PBEO/ TZVP) gave acceptable agreement with the experimental spectrum by reproducing the major transitions but failing for the sign of two weak transitions at around 225 and $280 \mathrm{~nm}$ (Fig. 3 and Fig. S3). This may result from the underestimation of conformers $C$ and $E$ (CAMB3LYP optimization) which gave a better agreement with the experimental ECD as compared to other highly-populated conformers (Fig. S2). The consistent results obtained at all the applied combinations of methods allowed the unambiguous elucidation of the absolute configuration of $\mathbf{1}$ as $(R)$. The analysis of computed orbitals revealed that the highest wavelength positive ECD transition at around $350 \mathrm{~nm}$ is of $\pi-\pi^{*}$ origin, while the $n-\pi^{*}$ ECD transition appeared as an overlapping positive one at about $310 \mathrm{~nm}$.

Compound 2 was obtained as a white amorphous solid. Its molecular formula was determined to be $\mathrm{C}_{15} \mathrm{H}_{16} \mathrm{O}_{4}$ as supported by the presence of a peak at $m / z 261.1124[\mathrm{M}+\mathrm{H}]^{+}$(calcd for 261.1121) in the HRESIMS spectrum. From the ${ }^{1} \mathrm{HNMR}$, JMOD, and HSQC spectra three methines $\left(\delta_{\mathrm{H}} 7.01 \mathrm{~s}, 6.52 \mathrm{~s}, 3.14 \mathrm{sept} ; \delta_{\mathrm{C}} 123.2,131.9\right.$, $26.8)$, three methyls $\left(\delta_{\mathrm{H}} 2 \times 1.10 \mathrm{~d}, 2.60 \mathrm{~s} ; \delta_{\mathrm{C}} 2 \times 21.6,23.6\right)$, eight nonprotonated carbons $\left(\delta_{\mathrm{C}} 185.8,185.7,157.7,153.8,144.8,140.2\right.$,

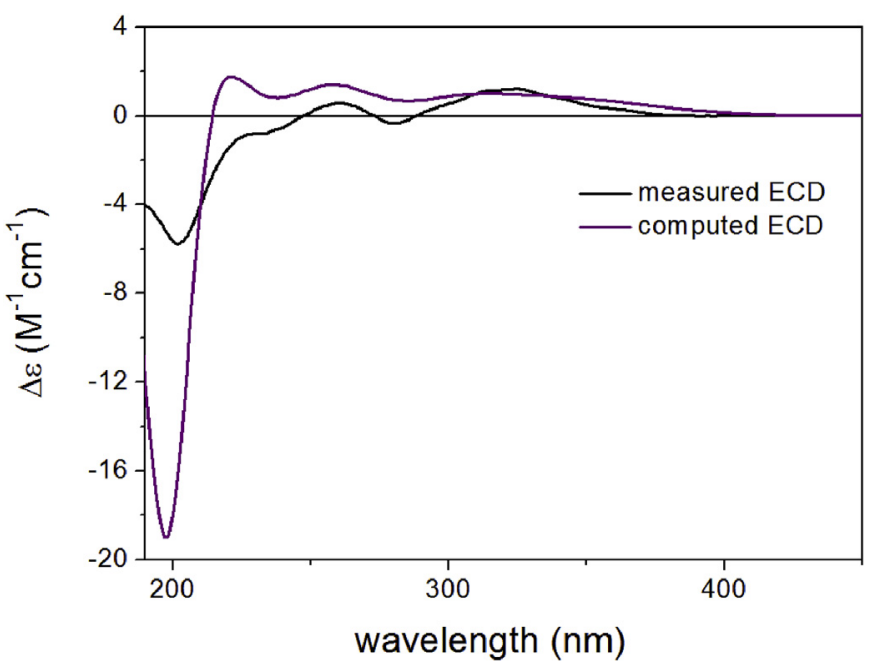

Fig. 3. Experimental ECD spectrum of $\mathbf{1}$ in $\mathrm{MeCN}$ (black line) compared with the Boltzmann-weighted PBE0/TZVP ECD spectrum of $(R)$-1 (Boltzmann average of 5 conformers, purple line) computed for the CAM-B3LYP/TZVP PCM/MeCN conformers.

125.2, and 124.2) and one methoxy group $\left(\delta_{\mathrm{H}} 3.85 \mathrm{~s} ; \delta_{\mathrm{C}} 62.1\right)$ were identified (Table 1). After the ${ }^{1} \mathrm{H}$ and ${ }^{13} \mathrm{C}$ NMR data of 2 had been assigned by analysis of its ${ }^{1} \mathrm{H}-{ }^{1} \mathrm{H}$ COSY, HSQC, and $\mathrm{HMBC}$ spectra, it was obvious that compounds $\mathbf{1}$ and $\mathbf{2}$ have the same 14noreudesmane skeleton. The ${ }^{1} \mathrm{H}^{-1} \mathrm{H}$ COSY spectrum of $\mathbf{2}$ defined an isopropyl group with correlated protons $\left(\mathrm{CH}_{3}\right)_{2}-\mathrm{CH}-\left[\delta_{\mathrm{H}} 1.10 \mathrm{~d}\right.$ $(6 \mathrm{H}), 3.14$ sept $(1 \mathrm{H})]$. The carbon chemical shifts at $\delta_{\mathrm{C}} 185.8$ and $185.7 \mathrm{ppm}(\mathrm{C}-6, \mathrm{C}-9)$ were indicative of a quinone structure which, together with further carbons ( $\mathrm{C}-1-\mathrm{C}-5, \mathrm{C}-7, \mathrm{C}-8, \mathrm{C}-10)$, form a $1,4-$ naphthoquinone skeleton. The isopropyl group can be located at $\mathrm{C}$ 7 with regard to the HMBC correlations of $\mathrm{H}-11$ (isopropyl methine) with $\mathrm{C}-7, \mathrm{C}-8$, and $\mathrm{C}-6$, and correlation between $\mathrm{H}-12, \mathrm{H}-13$ and $\mathrm{C}-7$. The tertiary methyl group (C-15) is attached to C-4 as demonstrated by heteronuclear long-range correlations of $\mathrm{H}-15$ with $\mathrm{C}-3, \mathrm{C}-4, \mathrm{C}-5$, and correlations between $\mathrm{H}-3 / \mathrm{C}-15$. The position of the methoxy group at $\mathrm{C}-1$ was suggested by the three-bond correlation between the methoxy protons at $\delta_{\mathrm{H}} 3.85$ and $\mathrm{C}-1\left(\delta_{\mathrm{C}}\right.$ 144.8). The hydroxy group is located at $\mathrm{C}-2$, as suggested by the molecular composition and the carbon resonance at $\delta_{\mathrm{C}} 153.8$. The alternative 1-OH and 2$\mathrm{OCH}_{3}$ structure was excluded because of the absence of a chelated hydroxy signal at lower field. Moreover, the HMBC correlations between $\mathrm{C}-6$ and $\mathrm{H}-8, \mathrm{C}-10$ and $\mathrm{H}-8, \mathrm{C}-5$ and $\mathrm{H}-3, \mathrm{C}-1$ and $\mathrm{H}-3$, and $\mathrm{C}-2$ and $\mathrm{H}-3$ were highly informative to elucidate the whole structure of 2 as 2-hydroxy-7-isopropyl-1-methoxy-4-methyl-1,4naphthoquinone. This compound can be regarded as a paraquinoid 14-noreudesmane, structurally related to compound 1. 14Noreudesmane sesquiterpenes comprise a rare group of natural compounds; such sesquiterpenes were isolated previously from Nicotiana tabacum (Solanaceae) [17], Alpinia oxyphylla (Zingiberaceae) [18], from the ascomycete Hypoxylon rickii [19], and from the edible mushroom Flammulina velutipes. [20].

Compound 3 was obtained as an amorphous solid with $[\alpha]_{D}+19$ (c 0.1, MeOH), and its molecular formula was determined by HRESIMS as $\mathrm{C}_{20} \mathrm{H}_{24} \mathrm{O}_{5}$ with the sodium adduct ion at $\mathrm{m} / \mathrm{z} 367.1516$ $[\mathrm{M}+\mathrm{Na}]^{+}$(calcd $m / z 367.1516$ for $\mathrm{C}_{20} \mathrm{H}_{24} \mathrm{O}_{5} \mathrm{Na}$ ). The ${ }^{1} \mathrm{H}$ NMR spectrum revealed the presence of six aromatic protons $\left[\delta_{\mathrm{H}} 6.92(2 \mathrm{H})\right.$, $6.85(2 \mathrm{H}), 6.93(1 \mathrm{H})$ and $6.87(1 \mathrm{H})]$, four methines $\left(\delta_{\mathrm{H}} 6.35 \mathrm{dd}, 6.15\right.$ $\mathrm{dq}, 4.61 \mathrm{~d}$ and $4.08 \mathrm{dq}$, each $1 \mathrm{H})$, two methyls $\left(\delta_{\mathrm{H}} 1.87 \mathrm{dd}\right.$ and $1.16 \mathrm{~d}$, each $3 \mathrm{H})$, and two methoxy groups $\left(\delta_{\mathrm{H}} 3.88 \mathrm{~s}\right.$ and $3.91 \mathrm{~s}$, each $\left.3 \mathrm{H}\right)$ (Table 2). The ${ }^{1} \mathrm{H}_{-}{ }^{1} \mathrm{H}$ COSY spectrum provided four sequences of correlated protons: $-\mathrm{CH}=\mathrm{CH}-\mathrm{CH}_{3}\left(\delta_{\mathrm{H}} 6.35 \mathrm{~d}, 6.15 \mathrm{dd}, 1.87 \mathrm{dd}\right)$ 
Table 2

${ }^{1} \mathrm{H}$ and ${ }^{13} \mathrm{C}$ NMR spectroscopic data of compound 3 [500 MHz $\left({ }^{1} \mathrm{H}\right), 125 \mathrm{MHz}\left({ }^{13} \mathrm{C}\right)$, $\left.\mathrm{CDCl}_{3}, \delta(\mathrm{ppm})(J=\mathrm{Hz})\right]$.

\begin{tabular}{lll}
\hline Position & ${ }^{1} \mathrm{H}$ NMR & ${ }^{13} \mathrm{C}$ NMR \\
\hline 1 & - & 145.7 \\
2 & - & 151.1 \\
3 & $6.92 \mathrm{brs}$ & 109.5 \\
4 & - & 133.7 \\
5 & $6.85 \mathrm{~m}$ & 119.0 \\
6 & $6.93 \mathrm{~m}$ & 119.3 \\
7 & $6.35 \mathrm{app} \mathrm{dd}(15.7,1.2)$ & 130.7 \\
8 & $6.15 \mathrm{dq}(15.7,6.7)$ & 125.1 \\
9 & $1.87 \mathrm{dd}(6.7,1.2)$ & 18.6 \\
$1^{\prime}$ & - & 147.0 \\
$2^{\prime}$ & - & 146.8 \\
$3^{\prime}$ & $6.92 \mathrm{brs}$ & 109.6 \\
$4^{\prime}$ & - & 132.2 \\
$5^{\prime}$ & $6.85 \mathrm{~m}$ & 121.0 \\
$6^{\prime}$ & $6.87 \mathrm{~m}$ & 114.3 \\
$7^{\prime}$ & $4.61 \mathrm{~d}(8.4)$ & 78.7 \\
$8^{\prime}$ & $4.08 \mathrm{dq}(8.4,7.0)$ & 84.5 \\
$9^{\prime}$ & $1.16 \mathrm{~d}(7.0)$ & 17.3 \\
$2-\mathrm{OCH}_{3}$ & $3.91 \mathrm{~s}$ & 56.0 \\
$2^{\prime}-\mathrm{OCH}_{3}$ & $3.88 \mathrm{~s}$ & 56.2 \\
\hline
\end{tabular}

(propenyl group) and $-\mathrm{CH}(\mathrm{OH})-\mathrm{CH}(\mathrm{OH})-\mathrm{CH}_{3}\left(\delta_{\mathrm{H}} 4.61 \mathrm{~d}, 4.08 \mathrm{dq}\right.$, $1.16 \mathrm{~d}$ ), and $2 \times 3$ protons representing two aromatic rings. After the ${ }^{13} \mathrm{C}$ NMR assignments were made on the basis of the JMOD and HSQC spectra, it was evident that compound $\mathbf{3}$ is a methoxysubstituted phenylpropane dimer. The heteronuclear long-range correlations detected in the HMBC spectrum were used to determine the position of the substituents on the aromatic rings. The location of the propenyl group at $\mathrm{C}-4$ was deduced from the observed HMBC correlations between $\mathrm{H}-7$ and $\mathrm{C}-3, \mathrm{C}-4$, and $\mathrm{C}-5$, while the position of unit $-\mathrm{CH}(\mathrm{OH})-\mathrm{CH}(\mathrm{OH})-\mathrm{CH}_{3}$ at $\mathrm{C}-4^{\prime}$ was established by the HMBC cross-peaks of $\mathrm{H}^{-} 7^{\prime}$ with $\mathrm{C}-3^{\prime}, \mathrm{C}-4^{\prime}$, and $\mathrm{C}-$ $5^{\prime}$. The methoxy groups $\left(\delta_{\mathrm{H}} 3.91\right.$ and 3.88$)$ were determined to be located at C-2 and C- $2^{\prime}$, respectively, with regard to their threebond correlations with the corresponding carbons. The molecular composition of 3 and chemical shifts of $\mathrm{C}-1, \mathrm{C}-1^{\prime}$ at $\delta_{\mathrm{C}} 145.7$ and 147.0 proved the connection of the phenylpropane units through an $O$ atom in position $\mathrm{C}-1-\mathrm{C}-\mathbf{1}^{\prime}$. The olefin bond of propenyl group ( $\mathrm{C}$ 7, C-8) must have $E$ geometry, as indicated by the coupling constant of $J 7,8=15.7 \mathrm{~Hz}$. The threo structure was elucidated for $\mathrm{H}-7^{\prime} / \mathrm{H}-8^{\prime}$ from the coupling constant of $J_{7^{\prime}, 8^{\prime}}=8.4 \mathrm{~Hz}$ (for the erythro form $J_{7^{\prime}, 8^{\prime}}$ is usually $5 \mathrm{~Hz}$ ) [21]. The absolute configuration of compound $\mathbf{3}$ was not determined.

Compound 4 was identified as caulilexin $C$ after evaluation of its APCIMS and 1D and 2D NMR spectra. This compound belongs to the group of phytoanticipins, which are produced by some crucifers, for example by Brassica oleraceae or Brassica rapa cultivars infected with Albugo candida or elicited by UV light [22]. Caulilexins are derived from tryptophan, and therefore contain an indole moiety attached to different functional groups; indol glucosinolates are regarded as their biosynthetic precursors [23].

Uvaol was also isolated and identified by comparison of its NMR chemical shifts with published data $[24,25]$. This compound was previously isolated from the seeds of E. rhamnoides [26].

\subsection{Antiviral activity of compounds $1-3$ and 5-8}

The isolated compounds 1-3 and a structurally close naphtoquinone and substituted naphtalenes 5-8, obtained from $R$. aquaticus by our group were investigated for antiviral activity [7]. First, the cytotoxicity of compounds $\mathbf{1}-\mathbf{3}$ and $\mathbf{5}-\mathbf{8}$ was tested at a concentration of $100-0.78 \mu \mathrm{M}$. All the compounds were dissolved in DMSO and diluted in culture medium. The maximum concentration of DMSO showed no cytotoxicity for Vero cells. After $24 \mathrm{~h}$ of incubation, cell viability was determined by the MTT test. The compounds showed a $\mathrm{CC}_{50}$ value higher than $100 \mu \mathrm{M}$, except for compound 8, which was rather toxic for Vero cells with a $\mathrm{CC}_{50}$ value of $6.25 \mu \mathrm{M}$ (data not shown).

To evaluate the possible antiviral effect of sea buckthorn compounds, HSV-2 infected (MOI: 0.01) Vero cells were treated with a series of 2 -fold diluted (100- $0.78 \mu \mathrm{M})$ compounds. After one day of incubation the supernatants from the wells were harvested, and viral yield was titrated. Applying this traditional virus yield reduction assay, compounds $\mathbf{1}$ and $\mathbf{3}$ was found to cause a $2 \log _{10}$ and $3.49 \log _{10}$ reduction of HSV-2 yield, respectively, at a concentration of $12.5 \mu \mathrm{M}$, compared to the virus titre of untreated control samples (Fig. 4A). This finding is in line with literature data, which demonstrate that acyclovir, the gold standard of anti-HSV therapy, produces a $1-5.06 \log _{10}$ reduction of HSV-2 yield at a concentration of $6.25 \mu \mathrm{M}$ [27]. Compound 2 exerted antiviral activity at concentrations of $50 \mu \mathrm{M}$ or higher only. Musizin (5) has antiviral activity at a concentration of $12.5 \mu \mathrm{M}$, causing a $2.33 \log _{10}$ reduction in virus yield (Fig. 4C). The anti-HSV-2 effect of musizin (5) demonstrated in our experiments is concordant with the result of Gescher et al. who reported the anti-HSV-1 activity of this compound [28].

To validate our results, the direct qPCR method was used [29] to determine the level of HSV-2 growth inhibition induced by serial dilutions of the compounds in the virus-infected cells. Similarly to our findings from the yield reduction assay, inhibition curves based on the qPCR results showed that the most potent compounds against HSV-2 were compounds 1 and $\mathbf{3}$ (Fig. 4B). The maximum HSV-2 growth corresponded to a DNA concentration of $\mathrm{Ct} \sim 15$ in the direct qPCR assay. The compound concentration that decreased HSV-2 growth and corresponding DNA content by 50\% ( $\left.\mathrm{IC}_{50}\right)$, increased the qPCR $\mathrm{Ct}$ value by approximately one cycle. Also, the compound concentration that inhibited HSV-2 growth by $90 \%$ ( $\left.\mathrm{IC}_{90}\right)$, raised the $\mathrm{Ct}$ value by $\sim 3.32$ cycles. In case of compounds 1 and 3 the $\mathrm{IC}_{50}$ and $\mathrm{IC}_{90}$ values were between 6.25 and $12.5 \mu \mathrm{M}$, while the $\mathrm{IC}_{50}$ value for compound $\mathbf{2}$ was $\sim 25 \mu \mathrm{M}$ and the IC 90 value for compound 2 was between 25 and $50 \mu \mathrm{M}$ (Fig. 4B). Musizin (5) also exerted a high antiviral activity with an $\mathrm{IC}_{50}$ of $\sim 12.5 \mu \mathrm{M}$ and $\mathrm{IC}_{90}$ of $25-50 \mu \mathrm{M}$ (Fig. 4D). Torachrysone-8-O-glucoside (7) had no effect on HSV-2 growth in the concentration range applied, while the $\mathrm{IC}_{50}$ value for musizin-8-O-glucoside (6) was $\sim 25 \mu \mathrm{M}$ and the IC 90 value was between 50 and $100 \mu \mathrm{M}$. 2-methoxystipandron (8) did not show any antiviral effect at the non-toxic concentration of $6.25 \mu \mathrm{M}$ (data not shown).

\section{Conclusions}

The present paper reports the occurrence of sesquiterpenes ( $\mathbf{1}$, 2), a phenylpropane heterodimer (3), and caulilexin $C(4)$ in E. rhamnoides for the first time. Sesquiterpenes $\mathbf{1}$ and $\mathbf{2}$ are based on the rare 14-noreudesmane skeleton. Compound $\mathbf{1}$ was identified as 6,9-dihydroxy-1-oxo-14-noreudesm-5,7,9-triene, its absolute configuration was determined by the TDDFT-ECD method. In addition, uvaol was isolated from the fruit peel; this compound was isolated previously from the seed of the plant [26].

The dose dependent inhibitory effect of certain sesquiterpenes (1, 2), phenylpropane dimer (3), naphthalenes (5-7), and 1,4naphthoquinone $(\mathbf{8})$ derivatives isolated from $E$. rhamnoides $(\mathbf{1}-\mathbf{3})$ and $R$. aquaticus $(\mathbf{5}-\mathbf{8}$ ) were investigated against HSV-2 virus infected Vero cells, by applying the traditional virus yield reduction test and the qPCR method. Compounds $\mathbf{1}$ and $\mathbf{3}$, as well as musizin (5) were demonstrated to have a potent anti-HSV-2 activity. In case of glucosides, such as musizin-8-O-glucoside (6), only a moderate anti-HSV-2 activity was observed.

Isolating two new 14-noreudesmane sesquiterpenes $(\mathbf{1}, \mathbf{2})$ from 


\section{A}
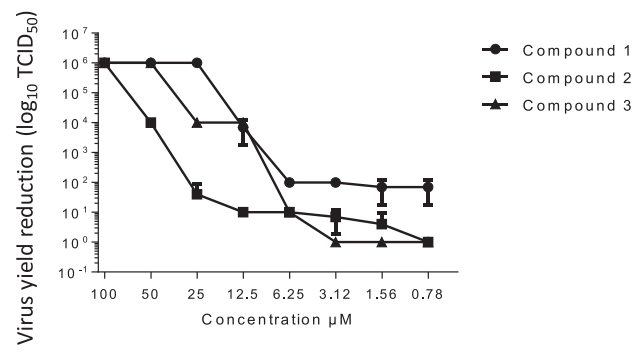

B

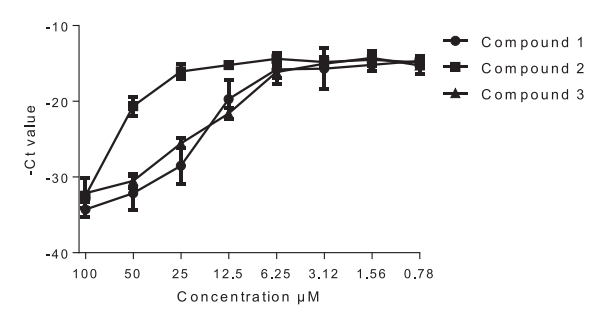

C

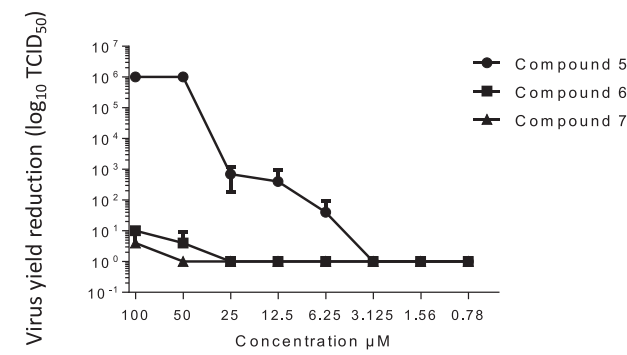

D

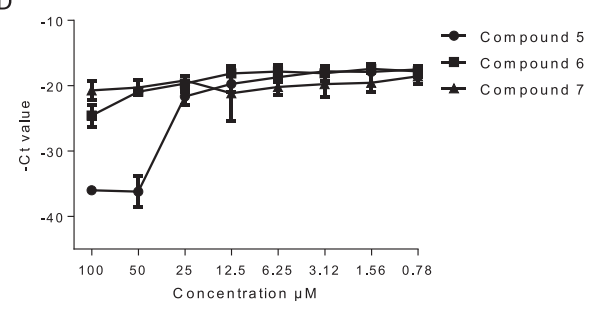

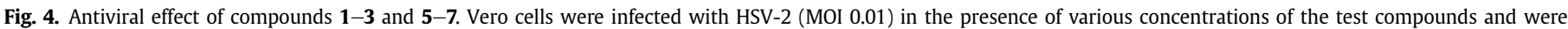

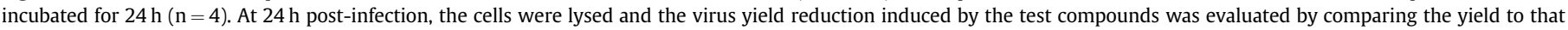

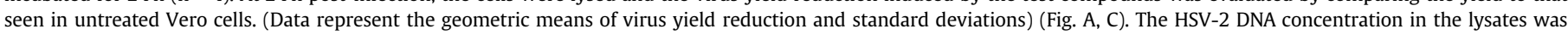
measured by direct qPCR (Fig. B, D). (Data represent the average $-\mathrm{Ct}$ values \pm standard deviations).

sea buckthorn, and demonstrating the antiviral properties of several compounds present in the fruit peel of the plant are significant novelties of our study. Based on our results, sea buckthorn is worth being further studied, as it could be a potential source of agents with considerable anti-HSV-2 activity, and thus it might provide alternative drug candidates for the treatment of patient populations infected with acyclovir- and penciclovir-resistant strains of the virus.

\section{Experimental}

\subsection{General procedures}

Optical rotations were measured in $\mathrm{MeOH}$ by using a PerkinElmer 341 polarimeter. NMR spectra were recorded in $\mathrm{CDCl}_{3}$ on a Bruker Avance DRX 500 spectrometer at $500 \mathrm{MHz}\left({ }^{1} \mathrm{H}\right)$ and $125 \mathrm{MHz}\left({ }^{13} \mathrm{C}\right)$, and on a Bruker Ultrashield Plus 600 spectrometer at $600 \mathrm{MHz}\left({ }^{1} \mathrm{H}\right)$ and $150 \mathrm{MHz}\left({ }^{13} \mathrm{C}\right)$. The peak of the residual solvent $\left(\delta_{\mathrm{H}} 7.26, \delta_{\mathrm{C}} 77.2\right)$ was taken as reference. In the ${ }^{1} \mathrm{H}-{ }^{1} \mathrm{HCOSY}$, HSQC, and HMBC experiments, gradient-enhanced versions were employed. Data were recorded and processed with the MestReNova v6.0.2-5475 software. Chemical shifts are expressed in parts per million, and coupling constant $(J)$ values are reported in Hz. Lowresolution ESI mass spectra were recorded on an API 2000 triple quadrupole mass spectrometer equipped with an electrospray interface. High-resolution MS data were recorded on a Thermo Q Exactive mass spectrometer equipped with an ESI electrospray source. The resolution was above 40,000. Data were recorded and processed with the Thermo Xcalibur software. ECD spectra were recorded on a JASCO J-810 spectropolarimeter.

For vacuum-liquid chromatography (VLC) silica gel $\left(60 \mathrm{GF}_{254}\right.$, $15 \mu \mathrm{m}$, Merck) and reversed phase silica gel (LiChroprep RP-18, 40-63 $\mu \mathrm{m}$, Merck) were used. Pre-coated normal phase silica gel plates $\left(60 \mathrm{~F}_{254}, 0.25 \mathrm{~mm}\right.$, Merck) and reversed phase silica gel plates (60 RP-18 $\mathrm{F}_{254} \mathrm{~S}$, Merck) were used for thin-layer chromatography (TLC) analyses and preparative TLC. Spots were visualized by heating $\left(105^{\circ} \mathrm{C}\right)$ after spraying the plates with concentrated $\mathrm{H}_{2} \mathrm{SO}_{4}$.
Centrifugal planar chromatography (CPC) was performed on selfcoated silica gel $\left(60 \mathrm{GF}_{254}, 15 \mu \mathrm{m}\right.$, Merck) and aluminium oxide (60G neutral, type E) plates using a Chromatotron instrument (Harrison Research).

\subsection{Plant material}

E. rhamnoides was organically cultivated and harvested in Fajsz, Hungary. Dried peel were donated by Bio-Drog-Berta Ltd., Kalocsa, Hungary. The plant was identified by Zoltán Berta. A voucher specimen has been deposited at the herbarium of the Institute of Pharmacognosy, University of Szeged (voucher no. 878).

\subsection{Extraction and isolation}

Dried peel ( $3 \mathrm{~kg}$ ) was percolated at room temperature with $70 \%$ $\mathrm{MeOH}(30 \mathrm{~L})$. The crude extract was concentrated $(2 \mathrm{~L})$ and partitioned with $\mathrm{CHCl}_{3}(6 \times 1.5 \mathrm{~L})$. The $\mathrm{CHCl}_{3}$ fraction $(27 \mathrm{~g})$ was submitted to VLC on silica gel column (A) using a step gradient of $n$ hexane-acetone 9:1 $(600 \mathrm{~mL}), 8: 2(500 \mathrm{~mL}), 7: 3(500 \mathrm{~mL}), 6: 4$ $(500 \mathrm{~mL}), 4: 6(500 \mathrm{~mL}), 3: 7(500 \mathrm{~mL})$ and acetone $300 \mathrm{~mL}$ to yield 68 fractions. Fractions of $50 \mathrm{~mL}$ were collected and monitored by TLC. Fractions A1-20 (2.4 g), A21-31 (2.7 g), A32-41 (2.7 g), A42-49 (2.1 g), A50-55 (3.8 g), A56-61 (1.1 g) and A62-68 (3.5 g) were combined. Fractions A21-31 was fractionated by VLC on silica gel column (B) with cyclohexane- $\mathrm{CH}_{2} \mathrm{Cl}_{2}-\mathrm{MeOH}$ mixtures (20:60:0, 20:60:1, 20:60:1.2, 20:60:1.6, 20:60:2) as eluent, collecting 66 fractions. Fractions B18-27 $(12.0 \mathrm{mg})$ were purified by preparative RP TLC using acetonitrile $-\mathrm{H}_{2} \mathrm{O}$ 7:3 as mobile phase and afforded compound 1 (10.3 mg). Fractions B40-60 (1.15 g) were submitted to CPC on silica gel plate (C) using a step gradient of $n$ hexane- $\mathrm{CH}_{2} \mathrm{Cl}_{2}-\mathrm{MeOH}$ to yield 45 fractions. Fractions $\mathrm{C} 20-29$ were chromatographed by $\mathrm{CPC}$ on $\mathrm{Al}_{2} \mathrm{O}_{3}$ plate using a step gradient of $n$-hexane-acetone, and pure compounds 2 ( $2.8 \mathrm{mg}), \mathbf{4}$ $(1.5 \mathrm{mg})$, and $5(5.8 \mathrm{mg})$ were isolated. VLC fractions B58-70 (35.0 mg) were fractionated by VLC on RP silica gel column (D) with acetonitrile $-\mathrm{H}_{2} \mathrm{O}$ mixtures (3:7, 4:6, 1:1, 6:4, 7:3, 8:2) as eluent, 
collecting 60 fractions. Fractions D28-33 were purified by preparative TLC using cyclohexane- $\mathrm{CH}_{2} \mathrm{Cl}_{2}-\mathrm{MeOH}$ 5:15:1 as mobile phase and afforded compound 3 (12.3 $\mathrm{mg}$ ).

\subsection{1. (R)-6,9-Dihydroxy-1-oxo-14-noreudesm-5,7,9-triene (1)} Amorphous solid; $[\alpha]_{\mathrm{D}}^{26}-18$ (c 0.2, $\left.\mathrm{MeOH}\right) ;{ }^{1} \mathrm{H}$ NMR $(500 \mathrm{MHz}$, $\left.\mathrm{CDCl}_{3}\right)$ and ${ }^{13} \mathrm{C}$ NMR $\left(125 \mathrm{MHz}, \mathrm{CDCl}_{3}\right)$ data, see in Table 1; ECD $\left(\mathrm{MeCN}, \lambda[\mathrm{nm}](\Delta \varepsilon), \mathrm{c} 5.34 \times 10^{-4} \mathrm{M}\right): 325(+1.22), 312 \mathrm{sh}(+1.08)$, 280 ( -0.33$), 261(+0.60), 232 \mathrm{sh}(-0.80), 202(-5.77)$; HRESIMS $m / z$ $235.1329[\mathrm{M}+\mathrm{H}]^{+}$calcd for $235.1329 \mathrm{C}_{14} \mathrm{H}_{19} \mathrm{O}_{3}$; ESIMS positive mode $m / z 235[\mathrm{M}+\mathrm{H}]^{+}, 220\left[\mathrm{M}+\mathrm{H}-\mathrm{CH}_{3}\right]^{+}, 205\left[\mathrm{M}+\mathrm{H}-2 \times \mathrm{CH}_{3}\right]^{+}$, $192,174,147,128$.

\subsubsection{2-Hydroxy-1-methoxy-6,9-dioxo-14-noreudesm-1,3,5(10),7- tetraene (2)}

Amorphous solid; ${ }^{1} \mathrm{H}$ NMR $\left(600 \mathrm{MHz}, \mathrm{CDCl}_{3}\right)$ and ${ }^{13} \mathrm{C} \mathrm{NMR}$ $\left(150 \mathrm{MHz}, \mathrm{CDCl}_{3}\right)$ data, see in Table 1 ; HRESIMS $\mathrm{m} / z 261.1124$ $[\mathrm{M}+\mathrm{H}]^{+}$calcd for $261.1121 \mathrm{C}_{15} \mathrm{H}_{17} \mathrm{O}_{4}$; ESIMS positive mode $\mathrm{m} / \mathrm{z} 261$ $[\mathrm{M}+\mathrm{H}]^{+}, 243\left[\mathrm{M}+\mathrm{H}-\mathrm{H}_{2} \mathrm{O}\right]^{+}, 219,207$.

\subsubsection{1-[3-Methoxy-4-(2-methoxy-4-(1E)-propenyl-phenoxy)-} phenyl]-propane-1,2-diol (3)

Amorphous solid; $[\alpha]_{\mathrm{D}}+19($ c $0.1, \mathrm{MeOH}) ;{ }^{1} \mathrm{H}$ NMR $(500 \mathrm{MHz}$, $\left.\mathrm{CDCl}_{3}\right)$ and ${ }^{13} \mathrm{C} \mathrm{NMR}\left(125 \mathrm{MHz}, \mathrm{CDCl}_{3}\right)$ data, see in Table 2; HRESIMS $\mathrm{m} / \mathrm{z} 367.1516[\mathrm{M}+\mathrm{Na}]^{+}$calcd for $367.1516 \mathrm{C}_{20} \mathrm{H}_{24} \mathrm{O}_{5} \mathrm{Na}, 327.1592$ $\left[\mathrm{M}+\mathrm{H}-\mathrm{H}_{2} \mathrm{O}\right]^{+}$calcd for 327.1596 .

\subsubsection{Caulilexin C (4)}

Yellow liquid; ${ }^{1} \mathrm{H}$ NMR $\left(600 \mathrm{MHz}, \mathrm{CDCl}_{3}\right) \delta \mathrm{ppm} 7.26(1 \mathrm{H}, \mathrm{s}, \mathrm{H}-2)$, $7.50(1 \mathrm{H}, \mathrm{d}, J=8.0 \mathrm{~Hz}, \mathrm{H}-4), 7.11(1 \mathrm{H}, \mathrm{dt}, J=7.5,0.5 \mathrm{~Hz}, \mathrm{H}-5), 7.25$ $(1 \mathrm{H}, \mathrm{dt}, J=7.5,0.5 \mathrm{~Hz}, \mathrm{H}-6), 7.39(1 \mathrm{H}, \mathrm{d}, J=8.0 \mathrm{~Hz}, \mathrm{H}-7), 3.75(2 \mathrm{H}, \mathrm{d}$, $J=0.7 \mathrm{~Hz}, \mathrm{H}-10), 4.03\left(3 \mathrm{H}, \mathrm{s}, \mathrm{OCH}_{3}\right) ;{ }^{13} \mathrm{C} \mathrm{NMR}\left(150 \mathrm{MHz}, \mathrm{CDCl}_{3}\right)$ $\delta$ ppm 121.7 (C-2), 117.9 (C-3), 118.4 (C-4), 120.5 (C-5), 123.3 (C-6), 108.7 (C-7), 132.3 (C-8), 122.4 (C-9), 14.3 (C-10), 100.3 (C-11), 66.2 $\left(\mathrm{OCH}_{3}\right) . \quad$ APCIMS $m / z \quad 187 \quad[\mathrm{M}+\mathrm{H}]^{+}, \quad 204\left[\mathrm{M}+\mathrm{H}+\mathrm{NH}_{3}\right]^{+}, \quad 251$ $[\mathrm{M}+\mathrm{H}+2 \times \mathrm{MeOH}]^{+}$.

\subsection{Computational methods}

Mixed torsional/low-frequency mode conformational searches were carried out by means of the Macromodel 10.8.011 software using the Merck Molecular Force Field (MMFF) with an implicit solvent model for $\mathrm{CHCl}_{3}$ [30]. Geometry reoptimizations were carried out at the B3LYP/6-31G(d) level in vacuo, and at the B97D/ TZVP [31,32] and the CAMB3LYP/TZVP [33] levels with the PCM solvent model for MeCN. TDDFT ECD calculations were run with various functionals (B3LYP, BH\&HLYP, CAM-B3LYP, PBE0), and the TZVP basis was set as implemented in the Gaussian 09 package with the same or no solvent model, as in the preceding DFT optimization step [34]. ECD spectra were generated as sums of Gaussians with $3000 \mathrm{~cm}^{-1}$ widths at half-height (corresponding to ca. $27 \mathrm{~nm}$ at $300 \mathrm{~nm}$ ), using dipole-velocity-computed rotational strength values [35]. Boltzmann distributions were estimated from the ZPVE-corrected B3LYP/6-31G(d) energies in the gas-phase calculations and from the B97D/TZVP and CAM-B3LYP/TZVP energies in the solvated ones. The MOLEKEL software package was used for visualization of the results [36].

\subsection{Cultivation and quantification of herpes viruses}

The HSV-2 strain (donated by Dr. Ilona Mucsi, University of Szeged, Szeged, Hungary) was grown in Vero cells (ATCC) and infectivity was measured in the same cell line by using the plaque titration method [27].
4.6. 3-(4,5-Dimethylthiazol-2-yl)-2,5-diphenyltetrazolium bromide (MTT) assay

MTT assay was carried out to identify the highest non-toxic concentration of compounds $\mathbf{1}-\mathbf{3}$ and 5-8 with potential antiviral activity. The medium was removed from Vero cells after an overnight period of growing, and fresh medium complemented with serial 2-fold dilutions of all compounds was added to three parallel wells for each concentration. After $24 \mathrm{~h}$ the MTT assay was performed as described earlier [37].

\subsection{Assays for testing antiviral activity}

The antiviral activity of sea buckthorn compounds was investigated in Vero cells. Cells were seeded in 96-well plates and were infected with HSV-2 at a multiplicity of infection (MOI) of 0.01 . After a $1 \mathrm{~h}$ adsorption period, the inoculum was removed, the cultures were washed twice, and culture medium containing the plant compounds in different concentrations was added. After a 24-hour incubation period, the cultures were washed with phosphate buffered saline, and finally $100 \mu \mathrm{L}$ Milli-Q water (MQ) (Millipore, Billerica, MA, USA) was added to the cells, and the cultures in the plate were frozen.

\subsubsection{Measuring antiviral activity using a qPCR method}

DNA release from the infected cells was achieved by two freeze-thaw cycles. $1 \mu \mathrm{L}$ of the lysates were used directly in a qPCR assay. Each antiviral test was performed in 3 parallel wells. The qPCR assay was performed using a Bio-Rad CFX96 real time system, as described earlier [29]. Briefly, a HSV-2 gD2 gene specific primer pair was applied during the qPCR process. The primer sequences were the following: gD2: 5'-TCA GCG AGG ATA ACC TGG GA-3', 5'GGG AGA GCG TAC TTG CAG GA-3'. The qPCR mixture consisted of $5 \mu \mathrm{L}$ SsoFast ${ }^{\mathrm{TM}}$ EvaGreen ${ }^{\circledR}$ Supermix (Bio-Rad, Hercules, CA, USA), 1$1 \mu \mathrm{L}$ of forward and reverse primers $(10 \mathrm{pmol} / \mu \mathrm{L}$ each $)$ and $1 \mu \mathrm{L}$ template, and $2 \mu \mathrm{L} \mathrm{MQ}$ water was added to get a final volume of $10 \mu \mathrm{L}$. After a 10 -min polymerase activation step at $95^{\circ} \mathrm{C}, 40 \mathrm{PCR}$ cycles of $20 \mathrm{~s}$ at $95^{\circ} \mathrm{C}$ and $1 \mathrm{~min}$ at $64^{\circ} \mathrm{C}$ were performed. Fluorescence intensity was detected at the end of the annealingextension step. The specificity of amplification was confirmed by melting curve analysis. For each PCR, the cycle threshold (Ct) corresponding to the cycle where the amplification curve crossed the base-line was determined.

\subsubsection{Determination of $T C I D_{50}$ by the virus yield reduction technique}

The virus yield in the supernatants of infected and plant compound-treated Vero cells was determined by the traditional dilution method. Vero cells $(60,000$ cells/well) were seeded onto 96-well flat-bottomed plates and cultivated for $24 \mathrm{~h}$ at $37^{\circ} \mathrm{C}$ at $5 \%$ $\mathrm{CO}_{2}$ to produce a semi-confluent monolayer. Then the growth medium was removed and 10 -fold dilutions of HSV-2 in the absence of the test compound (virus control), as well as compoundtreated HSV-2-infected cell supernatants were added in quadruplicate, and plates were incubated at $37^{\circ} \mathrm{C}$ until typical cytopathic effect (CPE) was visible. After $48 \mathrm{~h}$, the CPE of the virus was examined using an inverted microscope, and virus titres were estimated according to the Reed-Muench method, expressed as $\mathrm{TCID}_{50} / \mathrm{mL}$. The test compounds' antiviral activity was measured as the reduction of viral titre $\left(\log _{10}\right)$ in the presence of each compound, compared to the virus titre of the control sample.

\section{Acknowledgements}

Financial support from the Economic Development and 
Innovation Operative Programme GINOP-2.3.2-15-2016-00012 is gratefully acknowledged. Ministry of Human Capacities, Hungary grant 20391-3/2018/FEKUSTRAT is acknowledged. D. R. is a grantee of the János Bolyai Research Fellowship of the Hungarian Academy of Sciences. T. K. and A. M. thank the National Research, Development and Innovation Office (NKFI K 120181 and PD 121020) for financial support and the Governmental Information-Technology Development Agency (KIFÜ) for CPU time. The authors thank Dora Bokor, PharmD, for proof-reading the manuscript.

\section{Appendix A. Supplementary data}

Supplementary data to this article can be found online at https://doi.org/10.1016/j.tet.2019.01.050.

\section{References}

[1] T.A. Wani, S.M. Wani, M. Ahmad, M. Ahmad, A. Gani, F.A. Masoodi, F. Yildiz, Cogent Food Agric. 2 (2016) 1128519.

[2] M. Kruczek, A. Świderski, A. Mech-Nowak, K. Król, Acta Biochim. Pol. 59 (2012) $135-137$.

[3] G. Zakynthinos, T. Varzakas, Curr. Res. Nutr. Food Sci. 3 (2015) 89-97.

[4] J. Krejcarová, E. Straková, P. Suchý, I. Herzig, K. Karásková, Acta Vet. Brno 84 (2015) 257-268

[5] X. Yue XF, Z.J. Zhang, Y.N. Zhang, J. Food Drug Anal. 25 (2017) 327-332.

[6] D. Rédei, N. Kúsz, N. Jedlinszki, G. Blazsó, I. Zupkó, J. Hohmann, Planta Med. 84 (2018) 26-33.

[7] O. Orbán-Gyapai, E. Liktor-Busa, N. Kúsz, D. Stefkó, E. Urbán, J. Hohmann, A. Vasas, Fitoterapia 118 (2017) 101-106.

[8] T. Kurtán, S. Antus, G. Pescitelli, N. Berova, in: P.L. Polavarapu, K. Nakanishi, R.W. Woody (Eds.), Comprehensive Chiroptical Spectroscopy: Applications in Stereochemical Analysis of Synthetic Compounds, Natural Products, and Biomolecules, vol. 2, John Wiley \& Sons, New York, 2012, pp. 73-114.

[9] M. Moussa, W. Ebrahim, M. El-Neketi, A. Mándi, T. Kurtán, R. Hartmann, W. Lin, Z. Liu, P. Proksch, Tetrahedron Lett. 57 (2016) 4074-4078.

[10] P. Sun, J. Huo, T. Kurtán, A. Mándi, S. Antus, H. Tang, S. Draeger, B. Schulz, H. Hussain, K. Krohn, W. Pan, Y. Yi, W. Zhang, Chirality 25 (2013) 141-148.

[11] W.L. Geng, X.Y. Wang, T. Kurtán, A. Mándi, H. Tang, B. Schulz, P. Sun, W. Zhang, J. Nat. Prod. 75 (2012) 1828-1832.

[12] A. Evidente, S. Superchi, A. Cimmino, G. Mazzeo, L. Mugnai, D. Rubiales, A. Andolfi, A.M. Villegas-Fernández, Eur. J. Org. Chem. (2011) 5564-5570.

[13] S. Superchi, P. Scafato, M. Górecki, G. Pescitelli, Curr. Med. Chem. 25 (2018) 287-320.

[14] A. Mándi, I.W. Mudianta, T. Kurtán, M.J. Garson, J. Nat. Prod. 78 (2015) 2051-2056.

[15] P. Zhang, L.H. Meng, A. Mándi, T. Kurtán, X.M. Li, Y. Liu, X. Li, C.S. Li, B.G. Wang,
Eur. J. Org. Chem. (2014) 4029-4036.

[16] Y.S. Cai, T. Kurtán, Z.H. Miao, A. Mándi, I. Komáromi, H.L. Liu, J. Ding, Y.W. Guo, J. Org. Chem. 76 (2011) 1821-1830.

[17] C.A. Geng, X.Y. Huang, H. Wang, H.B. Xu, W.J. Liang, Y.B. Ma, X.M. Zhang J. Zhou, J.J. Chen, Fitoterapia 96 (2014) 81-87.

[18] D.H. Park, J.W. Lee, Q. Jin, W.K. Jeon, M.K. Lee, B.Y. Hwang, Bull. Korean Chem. Soc. 35 (2014) 1565-1567.

[19] E. Kuhnert, F. Surup, V. Wiebach, S. Bernecker, M. Stadler, Phytochemistry 117 (2015) 116-122.

[20] Q. Tao, K. Ma, Y. Yang, K. Wang, B. Chen, Y. Huang, J. Han, L. Bao, X.B. Liu, Z. Yang, W.B. Yin, H. Liu, J. Org. Chem. 81 (2016) 9867-9877.

[21] B.A.A.A. Balboul, A.A. Ahmed, H. Otsuka, A. Adams, Phytochemistry 42 (1996) 1191-1193.

[22] M.S.C. Pedras, Q.A. Zheng, R.S. Gadagi, S.R. Rimmer, Phytochemistry 69 (2008) 894-910.

[23] M.S.C. Pedras, M.G. Sarwar, M. Suchy, A.M. Adio, Phytochemistry 67 (2006) 1503-1509.

[24] S.B. Mahato, A.P. Kundu, Phytochemistry 37 (1994) 1517-1575.

25] J.S. Lee, H. Yoo, Y.G. Suh, J.K. Jung, J. Kim, Planta Med. 74 (2008) 1481-1487.

[26] T.S.C. Li, T.H.J. Beveridge, J.C.G. Drover, Food Chem. 101 (2007) 1633-1639.

[27] I. Mucsi, J. Molnár, N. Motohashi, Int. J. Antimicrob. Agents 18 (2001) 67-72.

[28] K. Gescher, A. Hensel, W. Hafezi, A. Derksen, J. Kühn, Antivir. Res. 89 (2011) $9-18$

[29] D.P. Virók, I. Eszik, T. Mosolygó, K. Önder, V. Endrész, K. Burián, J. Virol. Methods 242 (2017) 46-52.

[30] MacroModel, Schrödinger LLC, 2015. http://www.schrodinger.com/ MacroModel.

[31] S.J. Grimme, Comput. Chem. 27 (2006) 1787-1799.

[32] P. Sun, D.X. Xu, A. Mándi, T. Kurtán, T.J. Li, B. Schulz, W. Zhang, J. Org. Chem. 78 (2013) 7030-7047.

[33] T. Yanai, D. Tew, N. Handy, Chem. Phys. Lett. 393 (2004) 51-57.

[34] M.J. Frisch, G.W. Trucks, H.B. Schlegel, G.E. Scuseria, M.A. Robb, J.R. Cheeseman, G. Scalmani, V. Barone, B. Mennucci, G.A. Petersson, H. Nakatsuji, M. Caricato, X. Li, H.P. Hratchian, A.F. Izmaylov, J. Bloino, G. Zheng, J.L. Sonnenberg, M. Hada, M. Ehara, K. Toyota, R. Fukuda J. Hasegawa, M. Ishida, T. Nakajima, Y. Honda, O. Kitao, H. Nakai, T. Vreven, J.A. Montgomery Jr., J.E. Peralta, F. Ogliaro, M. Bearpark, J.J. Heyd, E. Brothers, K.N. Kudin, V.N. Staroverov, R. Kobayashi, J. Normand, K. Raghavachari, A. Rendell, J.C. Burant, S.S. Iyengar, J. Tomasi, M. Cossi, N. Rega, J.M. Millam, M. Klene, J.E. Knox, J.B. Cross, V. Bakken, C. Adamo, J. Jaramillo, R. Gomperts, R.E. Stratmann, O. Yazyev, A.J. Austin, R. Cammi, C. Pomelli, J.W. Ochterski, R.L. Martin, K. Morokuma, V.G. Zakrzewski, G.A. Voth, P. Salvador, J.J. Dannenberg, S. Dapprich, A.D. Daniels, Ö. Farkas, J.B. Foresman, J.V. Ortiz, J. Cioslowski, D.J. Fox, Gaussian 09, Revision E.01, Gaussian, Inc., Wallingford, CT, 2013.

[35] P.J. Stephens, N. Harada, Chirality 22 (2010) 229-233.

[36] U. Varetto, MOLEKEL, Swiss National Supercomputing Centre, Manno, Switzerland, 2009, 5.4.

[37] L. Párducz, I. Eszik, G. Wagner, K. Burián, V. Endrész, D.P. Virok, Lett. Appl. Microbiol. 63 (2016) 260-267. 